\section{Pacific Northwest}

National Laboratory

Operated by Battelle for the

U.S. Department of Energy

\title{
Joint Urban 2003: Study Overview and Instrument Locations
}

\author{
K. J. Allwine \\ J. E. Flaherty
}

August 2006

Prepared for the U.S. Department of Homeland Security under a Related Services Agreement with the U.S. Department of Energy under contract DE-AC05-76RL01830 


\title{
DISCLAIMER
}

This report was prepared as an account of work sponsored by an agency of the United States Government. Neither the United States Government nor any agency thereof, nor Battelle Memorial Institute, nor any of their employees, makes any warranty, express or implied, or assumes any legal liability or responsibility for the accuracy, completeness, or usefulness of any information, apparatus, product, or process disclosed, or represents that its use would not infringe privately owned rights. Reference herein to any specific commercial product, process, or service by trade name, trademark, manufacturer, or otherwise does not necessarily constitute or imply its endorsement, recommendation, or favoring by the United States Government or any agency thereof, or Battelle Memorial Institute. The views and opinions of authors expressed herein do not necessarily state or reflect those of the United States Government or any agency thereof.

\author{
PACIFIC NORTHWEST NATIONAL LABORATORY \\ operated by \\ BATTELLE \\ for the \\ UNITED STATES DEPARTMENT OF ENERGY \\ under Contract DE-ACO5-76RL01830
}

Printed in the United States of America

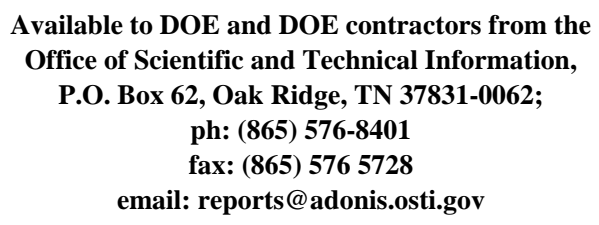

Available to DOE and DOE contractors from the Office of Scientific and Technical Information, P.O. Box 62, Oak Ridge, TN 37831-0062; ph: (865) 576-8401 fax: (865) 5765728

email: reports@adonis.osti.gov

\author{
Available to the public from the National Technical Information Service, \\ U.S. Department of Commerce, 5285 Port Royal Rd., Springfield, VA 22161 \\ ph: (800) 553-6847 \\ fax: (703) 605-6900 \\ email: orders@nits.fedworld.gov \\ online ordering: http://www.ntis.gov/ordering.htm
}




\title{
Joint Urban 2003: Study Overview and Instrument Locations
}

\author{
K. J. Allwine \\ J. E. Flaherty
}

August 2006

Prepared for the U.S. Department of Homeland Security under a Related Services Agreement with the U.S. Department of Energy under Contract DE-AC05-76RL01830

Pacific Northwest National Laboratory Richland, Washington 99352 


\section{Summary}

Quality-assured meteorological and tracer data sets are vital for establishing confidence that indoor and outdoor dispersion models used to simulate dispersal of potential toxic agents in urban atmospheres are giving trustworthy results. The U.S. Department of Defense-Defense Threat Reduction Agency and the U.S. Department of Homeland Security joined together to conduct the Joint Urban 2003 atmospheric dispersion study to provide this critically-needed high-resolution dispersion data. This major urban study was conducted from June 28 through July 31, 2003, in Oklahoma City, Oklahoma, with the participation of over 150 scientists and engineers from over 20 U.S. and foreign institutions. Through mid-2006 over 125 papers and presentations have been given on scientific findings and model evaluations based on the field study results.

The Joint Urban 2003 lead scientist was Jerry Allwine (Pacific Northwest National Laboratory) who oversaw study design, logistical arrangements and field operations with the help of Joe Shinn (Lawrence Livermore National Laboratory), Marty Leach (Lawrence Livermore National Laboratory), Ray Hosker (Atmospheric Turbulence and Diffusion Division), Leo Stockham (Northrop Grumman Information Technology) and Jim Bowers (Dugway Proving Ground).

This report gives a brief overview of the field campaign, describing the scientific objectives, the dates of the intensive observation periods, and the instruments deployed. The data from this field study is available to the scientific community through an on-line database that is managed by Dugway Proving Ground. This report will be included in the database to provide its users with some general information about the field study, and specific information about the instrument coordinates. Appendix A of this document provides the definitive record of the instrument locations during this field campaign, and Appendix B lists all the study principal investigators and participants. 



\section{Acronyms}

AGL

ANL

ARL

ARLFRD

ARO

ASU

ASOS

ATDD

CBD

CBNP

CDC

CDT

CFD

CFU

DARPA

DEQ

DHS

DOE

DOY

DPG

DSTL

DTRA

ECBC

FM-CW

GIS

IOP

IR

ITT

IU

LANL

above ground level

Argonne National Laboratory

Army Research Laboratory

Air Resources Laboratory Field Research Division

Army Research Office

Arizona State University

Automated Surface Observing System

Atmospheric Turbulence and Diffusion Division

central business district

Chemical Biological National Security Program (DOE)

Center for Disease Control

central daylight time

computational fluid dynamics

Central Florida University

Defense Advanced Research Projects Agency

Oklahoma Department of Environmental Quality

U.S. Department of Homeland Security

U.S. Department of Energy

day of year

Dugway Proving Ground

Defense Science and Technology Laboratory

Defense Threat Reduction Agency

Edgewood Chemical Biological Center

Frequency Modulated Continuous Wave Radar Profiler

geographic information system

intensive observation period

infrared

ITT Industries

Indiana University

Los Alamos National Laboratory 


$\begin{array}{ll}\text { LBNL } & \text { Lawrence Berkley National Laboratory } \\ \text { LLNL } & \text { Lawrence Livermore National Laboratory } \\ \text { NEPA } & \text { National Environmental Policy Act } \\ \text { NGIT } & \text { Northrop Grumman Information Technology } \\ \text { NIOSH } & \text { National Institute for Occupational Safety and Health } \\ \text { NSSL } & \text { National Severe Storms Laboratory } \\ \text { NWS } & \text { National Weather Service } \\ \text { OCS } & \text { Oklahoma Climatological Survey } \\ \text { OKC } & \text { Oklahoma City } \\ \text { OU } & \text { University of Oklahoma } \\ \text { PNNL } & \text { Pacific Northwest National Laboratory } \\ \text { TGA } & \text { Trace Gas Analyzer } \\ \text { TP9 } & \text { U.S. Department of Defense Technical Panel 9 } \\ \text { TTCP } & \text { The Technical Cooperation Program } \\ \text { TTU } & \text { Texas Tech University } \\ \text { UH } & \text { University of Houston } \\ \text { USGS } & \text { United States Geological Survey } \\ \text { UU } & \text { University of Utah } \\ \text { WSU } & \text { Washington State University }\end{array}$




\section{Acknowledgments}

This research was supported in part by the U.S. Department of Homeland Security under a Related Services Agreement with the U.S. Department of Energy (DOE) under Contract DE-AC05-76RL01830. Pacific Northwest National Laboratory (PNNL) is operated for DOE by Battelle Memorial Institute.

Joint Urban 2003 would not have been possible without the support of Oklahoma City (OKC), the University of Oklahoma Health Sciences Center, private land owners, and the general public. The OKC Public Works Department provided considerable help by allowing study participants to use some of their facilities for staging areas, allowed instrumentation to be placed on streets and public facilities, and provided parking downtown for study staff during experimental periods. Mr. Paul Brum, OKC City Engineer, and Mr. JC Reiss of the Public Works Department were instrumental in all aspects of logistical arrangements for conducting the study. Mr. Leon Ashford of the Oklahoma Department of Environmental Quality (DEQ) arranged for some elements of the study to be staged from DEQ facilities. Additionally, the University of Oklahoma Health Sciences Center was very generous in providing laboratory and meeting space within their facilities in OKC. Dr. Jeff Basara and Ms. Cerry Leffler of the Oklahoma Climatological Survey provided invaluable support in producing identification badges for all study participants and in arranging for many Oklahoma Climatological Survey and University of Oklahoma students to help with the field operations. Mr. Ron Rocke of Maccini Construction Co. arranged for the installation of several instrument systems in OKC and also arranged with Allied Steel Construction Co. for the receiving, shipping and storage of equipment needed for the study.

The success of Joint Urban 2003 was critically dependent on many individuals, not the least of whom were the scientists, engineers, technicians, students, and contractors from the participating organizations and companies. Project participants would like to thank several individuals who played key roles during various stages of planning and conducting the study. Ms. Jennifer Reichert of the U.S. DOE's Chemical Biological National Security Program (CBNP) was the CBNP program manager for the project and was instrumental in coordinating and integrating CBNP objectives with Defense Threat Reduction Agency (DTRA) objectives. Ms. Leslie Burchett followed-on for Ms. Reichert and ensured that DOE objectives were met in the field and also facilitated the smooth transition of Joint Urban 2003 from DOE to the new Department of Homeland Security (DHS), where the final DHS portion of Joint Urban 2003 was under the guidance of Ms. Teresa Lustig. Mr. John Pace was the DTRA Urban Modeling Program manager responsible for integrating DTRA objectives with CBNP objectives for Joint Urban 2003. Mr. Richard Fry was the DTRA program manager responsible for the DTRA portion of Joint Urban 2003.

The National Environmental Policy Act (NEPA) documentation for the study was prepared by Ms. Regan Weeks of PNNL and Mr. Geoff Harvey, PNNL, served as the lead public affairs contact for Joint Urban 2003. Ms. Cheri Abdelnour and Major Linda Ritchie were responsible for the public affairs on Joint Urban 2003 for DTRA, and Ms. Michelle Petrovich was responsible for DHS public affairs. Ms. Cerry Leffler of the Oklahoma Climatological Survey was the local public affairs contact for the study. 



\section{Contents}

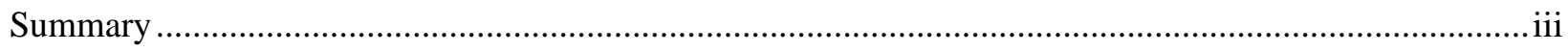

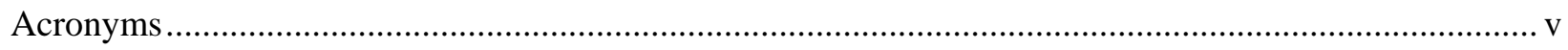

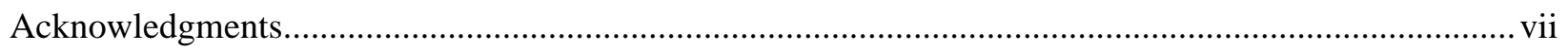

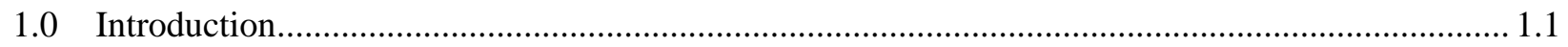

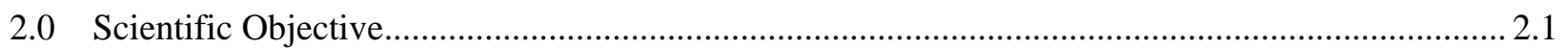

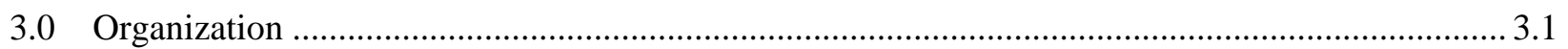

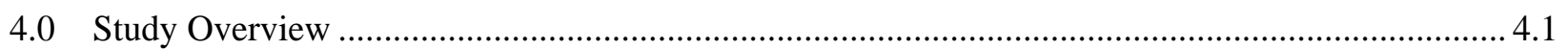

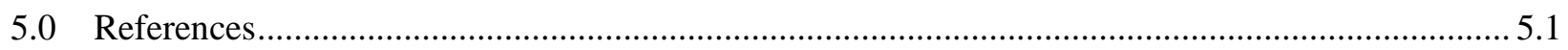

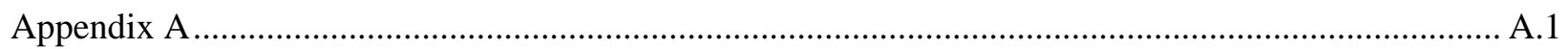

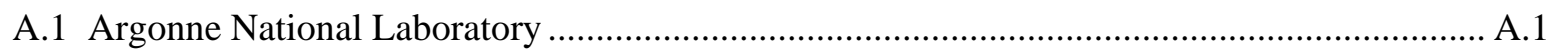

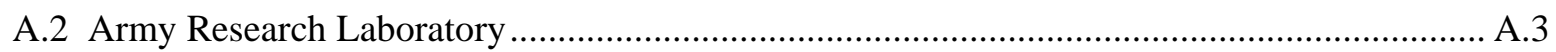

A.3 NOAA Air Resources Laboratory_Field Research Division .............................................. A.6

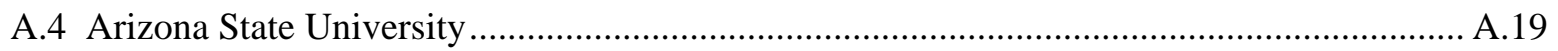

A.5 NOAA Air Resources Laboratory-Atmospheric Turbulence and Diffusion Division ........ A.21

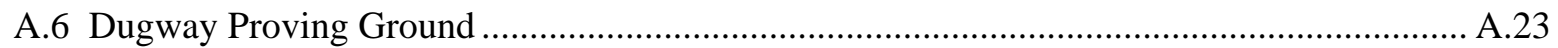

A.7 Defense Science and Technology Laboratory................................................................... A.29

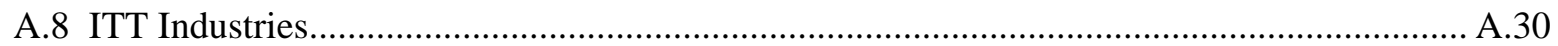

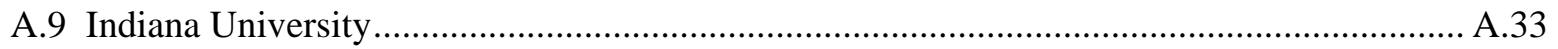

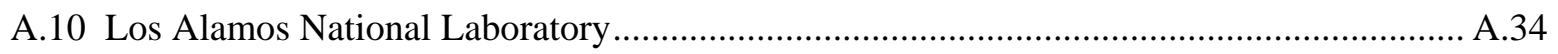

A.11 Lawrence Livermore National Laboratory................................................................... A.36

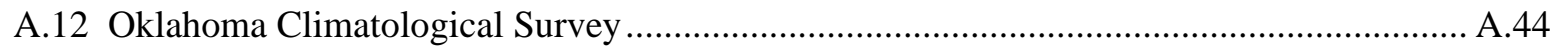

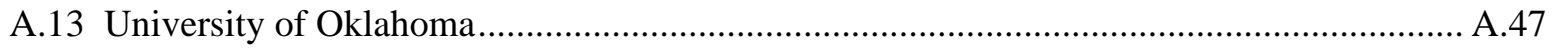

A.14 Pacific Northwest National Laboratory ……...................................................................... A.48

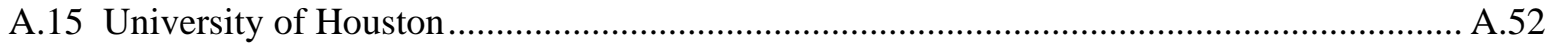




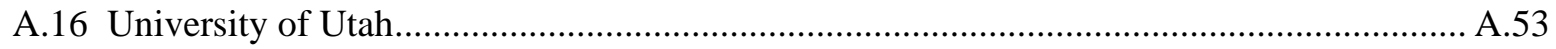

A.17 Volpe/University of Central Florida ............................................................................... A.54

A.18 Washington State University ……................................................................................... A.56

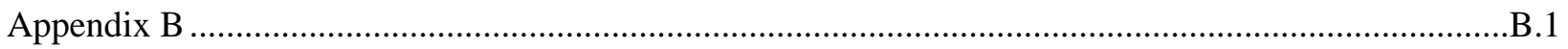




\section{Figures}

1.1. OKC Looking East in Top Panel and Looking South in Bottom Panel........................................ 1.1

4.1. Overview of Meteorological Measurement Sites Around OKC ................................................... 4.2

4.2. Instruments that were Located in the Park Ave Street Canyon .................................................... 4.3

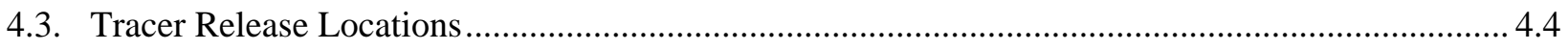

4.4. Hourly Averaged Meteorological Conditions for July 2003 Measured at $3 \mathrm{~m}$ Above the Rooftop on a 42-m-high Building with Unobstructed Exposure to the Winds.............................. 4.6

4.5. Overview of Tracer Sampler and Analyzer Instrument Locations .............................................. 4.7

A.1. Overview of ANL Instrument Locations ……............................................................................ A.2

A.2. ANL Instrument Locations: (a) Botanical, (b) $10^{\text {th }}$ and Harvey Site, (c) Goodholm Park, and (d) First Christian Church ....................................................................................................... A.3

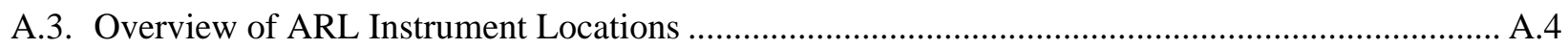

A.4. ARL Instrument Locations for (a) Tower 1, (b) Tower 2, (c) Tower 3, (d) Tower 4 and Rawindsonde, (e) Tower 5, and (f) Lidar and Radiometer ....................................................... A.5

A.5. Overview of ARLFRD PIGS and S-PIGS Tracer Sampler Instruments .................................... A.10

A.6. ARLFRD PIGS and S-PIGS Tracer Sampler Instruments, Zoomed into the 2-km Arc................ A.11

A.7. ARLFRD PIGS and S-PIGS Tracer Sampler Instruments, Zoomed into the 1-km Arc............... A.12

A.8. ARLFRD Trace Gas Analyzer Instrument Locations During (a) IOPs 1, 3, 4, \& 6, (b) IOP 2, (c) IOP 5, (d) IOP 7, (e) IOP 8, (f) IOP 9, and (g) IOP 10

A.9. ARLFRD $\mathrm{SF}_{6}$ Release Locations: $\mathrm{W}(\mathrm{E})=$ Westin (East), $\mathrm{W}=$ Westin, $\mathrm{B}=$ Botanical, $\mathrm{P}=$ Park, and $\mathrm{F}=$ Fourth

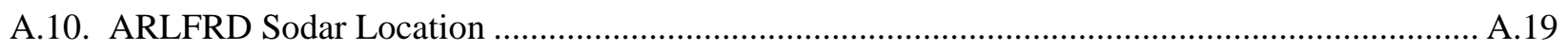

A.11. Overview of ASU Instrument Locations.......................................................................... A.20

A.12. ASU Instrument Locations: (a) Energy Tower, (b) Energy Tower with Neighboring Instrumentation Shown, (c) Park Tower, and (d) Lidar.

A.13. Overview of ATDD Instrument Locations

A.14. ATDD Instrument Locations at (a) Energy Flux Site A, (b) Energy Flux Site C, (c) Sonic Tower 1, and (d) Energy Flux Site B and Micro-barograph Pressure Sites 1 Through 3. 
A.15. Overview of DPG PWIDS and Super PWIDS Locations ..................................................... A.25

A.16. DPG PWIDS and SuperPWIDS in the Northern Portion of the CBD ..................................... A.26

A.17. DPG PWIDS and SuperPWIDS in the Central Portion of the CBD ........................................ A.26

A.18. DPG PWIDS and SuperPWIDS in the Southern Portion of the CBD .................................... A.27

A.19. DPG PWIDS on the Post Office Roof, South of the CBD ..................................................... A.27

A.20. Overview of DPG Profile Instrument Locations ..................................................................... A.28

A.21. DPG (a) Radar and Sodar, and (b) Tethersonde Locations.................................................... A.28

A.22. DSTL Sonic Anemometer Locations in Park Ave ................................................................. A.29

A.23. Overview of All ITT TGA Locations ….............................................................................. A.31

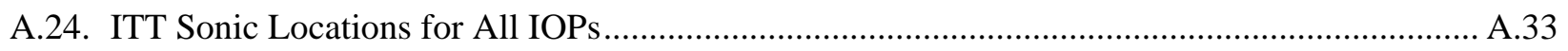

A.25. IU Energy and Sonic Tower Locations ............................................................................. A.34

A.26. LANL Sonic Anemometer Locations in Park Ave .............................................................. A.35

A.27. LLNL BlueBox Locations During (a) IOP 1 and 2, (b) IOP 3, (c) IOP 8, (d) IOP 9,

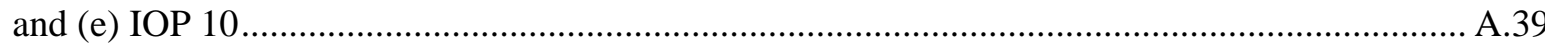

A.28. LLNL Miran Locations During (a) IOP 1, 2, and 8, (b) IOP 3, 5, 6, and 7, (c) IOP 4,

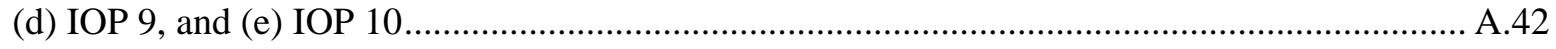

A.29. LLNL Sonic Anemometer Location ........................................................................................ A.43

A.30. Overview of OCS Meteorological Measurement Locations ..................................................... A.45

A.31. OCS Meteorological Measurement Locations (a) KFDR, (b) KVNS, (c) KING, (d) ELRE, (e) MINC, (f) GUTH, (g) KPWA, (h) KOKC, (i) NRMN and KOUN, (j) SPEN, (k) KTLX,

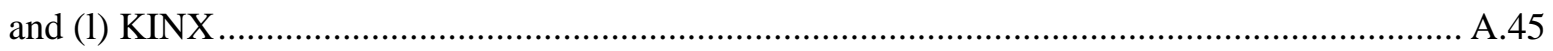

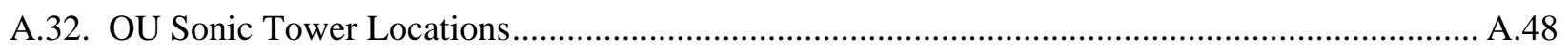

A.33. Overview of PNNL Meteorological Station and HOBO Locations.......................................... A.50

A.34. PNNL HOBO and Meteorological Station Locations......................................................... A.50

A.35. PNNL Profile Site at Shartel Avenue................................................................................... A.52

A.36. UH Sodar Location (a) with only the UH Instrument, and (b) with Neighboring ATDD and ASU Instruments

A.37. UU Sonic Anemometer (red X's) and Profile (red boxes) Measurement Locations (a) in Park Ave and (b) on the Broadway-Kerr Parking Garage 


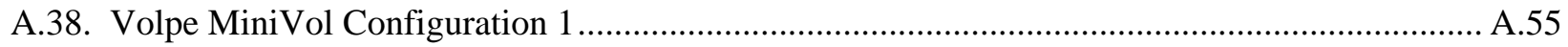

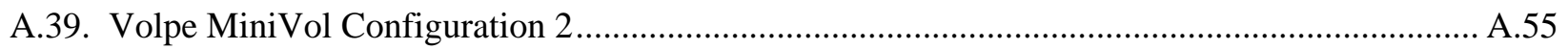

A.40. Volpe Sonic Anemometer Locations …............................................................................. A.56

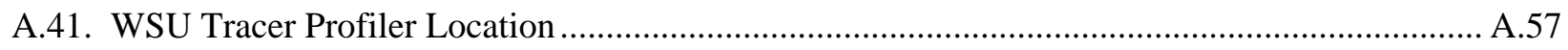




\section{Tables}

4.1. Summary of Intensive Observation Periods (IOPs) …............................................................... 4.4

4.2. Summary of IOP Tracer Release Rates and Times................................................................... 4.5

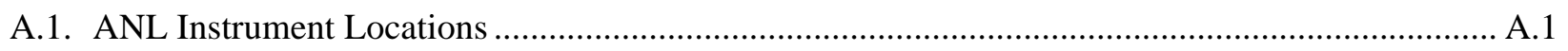

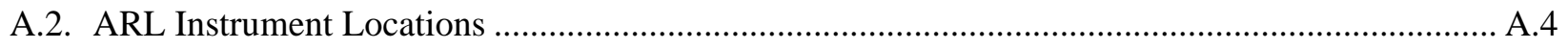

A.3. ARLFRD Tracer Sampler Instrument Locations .................................................................. A.6

A.4. ARLFRD Trace Gas Analyzer Instrument Locations.............................................................. A.13

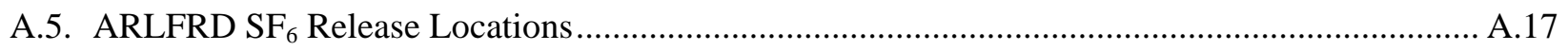

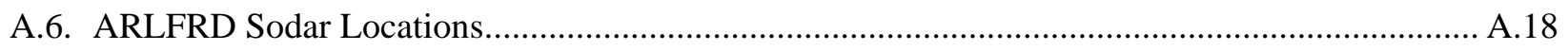

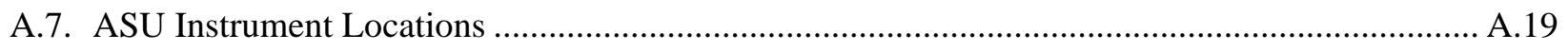

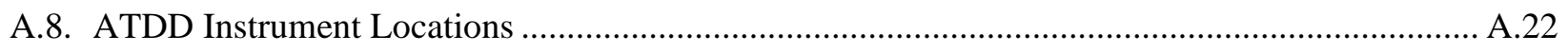

A.9. DPG PWIDS and SuperPWIDS Locations........................................................................ A.24

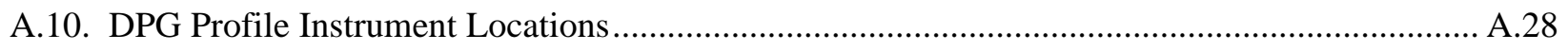

A.11. DSTL Sonic Anemometer Locations ................................................................................. A.29

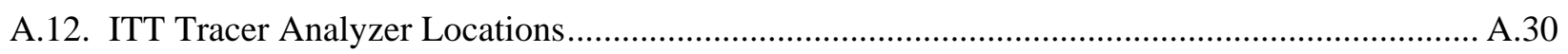

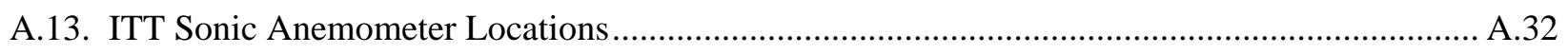

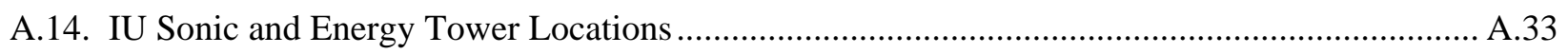

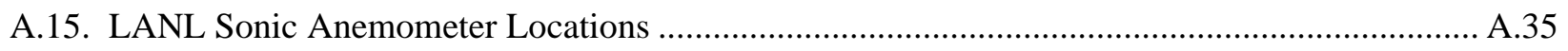

A.16. LLNL Tracer Sampler Locations for Each IOP ................................................................ A.36

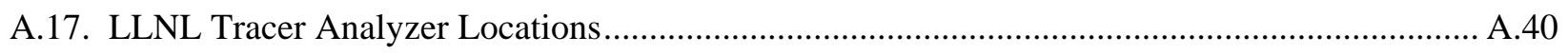

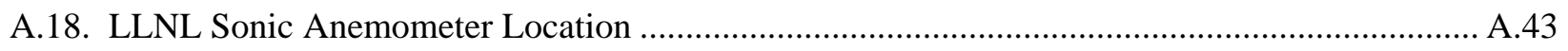

A.19. OCS Meteorological Measurement Locations (Note: KINX Tulsa is in UTM Zone 15) ............ A.44

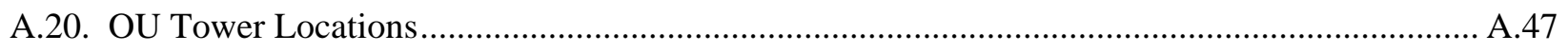

A.21. PNNL Meteorological Station, Profile, and HOBO Locations ................................................ A.49

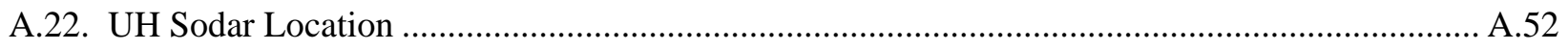


A.23. UU Sonic Anemometer and Profile Measurement Locations .................................................. A.53

A.24. Volpe Tracer Sampler and Sonic Anemometer Locations ........................................................... A.54

A.25. WSU Tracer Profiler Location ................................................................................................ A.56

B.1. Summary of Principal Investigators from the Participating Institutions of the Joint Urban 2003 Study B.1

B.2. Summary of Participants in the Joint Urban 2003 Study. B.2 


\subsection{Introduction}

Air motions in and around cities are very complicated and the increasing threat of toxic agent releases into urban atmospheres makes advancing the state-of-science of understanding and modeling atmospheric flows in and around cities essential. Quality-assured meteorological and tracer data sets are vital for establishing confidence that indoor and outdoor dispersion models used to simulate dispersal of potential toxic agents in urban atmospheres are giving trustworthy results. To provide this critically-needed highresolution dispersion data, the U.S. Department of Defense - Defense Threat Reduction Agency (DTRA) and the U.S. Department of Homeland Security (DHS) joined in an effort to conduct the Joint Urban 2003 atmospheric dispersion study in Oklahoma City (OKC), Oklahoma (Figure 1.1) during July, 2003.

Numerous investigators from government laboratories, universities, and private companies conducted the multi-million dollar OKC study. Additionally, investigators from several other U.S. federal agencies and foreign government agencies participated in the study.

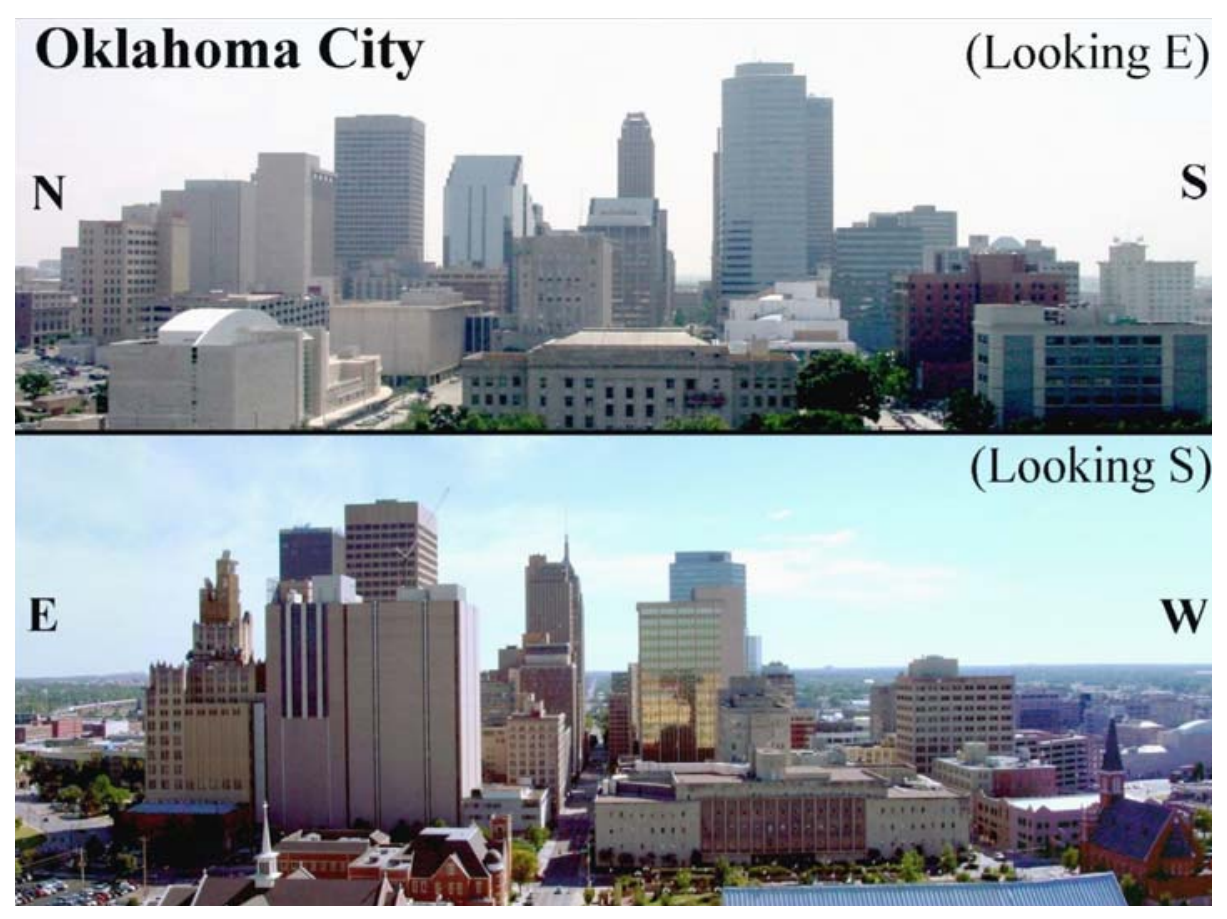

Figure 1.1. OKC Looking East in Top Panel and Looking South in Bottom Panel

This major urban study was conducted from June 28 through July 31, 2003. It included several integrated scientific components necessa2ry to describe and understand the physical processes governing dispersion within and surrounding an urban area and into and within building environments. The components included characterizing:

1) the urban boundary layer and the development of the urban boundary layer within the atmospheric boundary layer,

2) flows within and downwind of the tall-building core,

3) flows within a street canyon including the effects of traffic on turbulence,

4) surface energy balance within an urban area, 
5) dispersion of tracer into, out of, and within buildings, and

6) dispersion of tracer throughout the tall-building core and out to four kilometers downwind from the release.

The scientific elements of the study were accomplished using state-of-the-art meteorological and tracer instruments including lidars, sodars, radars, sonic anemometers, airplane-based meteorological sensors, fast-response tracer analyzers, and helicopter-based remote tracer detectors. Winds and other meteorological quantities were measured continuously at nearly 100 locations in and around downtown OKC.

Ten main intensive observation periods (IOPs) of 8-hours each were completed during the 34-day study period where detailed meteorological, turbulence and tracer measurements were made. Sulfur hexafluoride $\left(\mathrm{SF}_{6}\right)$ tracer was released in downtown $\mathrm{OKC}$ and sampled in and around downtown and as far as four kilometers downwind. During four of the ten IOPs, the infiltration of tracer into four downtown buildings was studied with detailed measurements of tracer and flows within and surrounding some buildings. Tracer was sampled using over 200 integrated samplers and 25 fast response analyzers. Vertical measurements of tracer were made by placing samplers on the tops of nearly 20 buildings and by sampling tracer at 7 levels on a 90-m crane.

An overview of the Joint Urban 2003 field study is presented, identifying scientific objectives and the deployment of instruments to accomplish the scientific objectives. Study participants, experimental periods and meteorological conditions during the study period are briefly discussed. 


\subsection{Scientific Objective}

The primary objective of the Joint Urban 2003 field study was to collect meteorological and tracer data resolving atmospheric dispersion at scales-of-motion ranging from flows in and around a single city block, in and around several blocks in the downtown Central Business District (CBD), and into the suburban OKC area a few kilometers from the CBD. Indoor tracer and flow measurements within four downtown study buildings were also made in conjunction with detailed outdoor measurements investigating the outdoor-indoor exchange rates and mechanisms. The movement of tracer within the study buildings was also investigated.

The tracer and meteorological data collected in OKC are being used to evaluate and improve existing indoor and outdoor dispersion models, including fine-scale computational fluid dynamics (CFD) models, mesoscale numerical weather prediction models with sub-grid scale urban parameterizations, and fastresponse dispersion models that typically rely on empirical or semi-empirical relationships describing atmospheric processes. The data will lead to improved algorithms and parameterizations within these models. If fact, through mid-2006 over 125 papers and presentations have been given on scientific findings and model evaluations based on the Joint Urban 2003 field study results.

Specific objectives of this field study included

- Use state-of-the-art remote sensing instruments (e.g., radar profilers, lidars, sodars) to continuously measure the detailed wind and turbulence characteristics of the urban atmosphere from the ground through several kilometers above the ground. These relatively new instruments, when applied in a dense network, give a view of the three-dimensional flow in and above cities that has not been possible in the past.

- Collect tracer data at various distances from specified release points to provide data for validating a variety of urban dispersion models. Networks of sampling capabilities and meteorological instruments were deployed to observe the concentrations at the various distances downwind, and to simultaneously investigate the physical processes that govern the dispersion.

- Use state-of-the-art in-situ meteorological instruments (e.g., sonic anemometers, infrared [IR] thermometers) to observe the winds and turbulence within the urban canopy layer. Together with time-resolved in-situ tracer sampling, these observations provide data necessary not only for validating current dispersion models, but also for improving current and formulating new dispersion algorithms and relationships.

- Conduct urban canyon experiments with high resolution wind and turbulence measurements together with tracer data to investigate the processes that disperse material within the canyon and the exchange of material between the canyon and the overall urban circulation.

- Conduct indoor experiments designed to investigate the exchange of tracer material through a building envelope. Tracer samplers and sonic anemometers were deployed inside the building and immediately outside the building in high-density configuration to estimate the exchange rate. Perfluorocarbon tracers were released and sampled inside the building to estimate transport within the building. 
- Provide an archived data set that has been quality-controlled and consistency-checked based on a detailed data management plan.

The Joint Urban 2003 experimental objectives have been accomplished, to the credit of all study participants, and the data has been submitted to the data archive, which is managed by Dugway Proving Ground. The secure data archive, available via the internet, was accessible only to study participants until January 31, 2005. Since then, the archive has been made publicly available for investigators and modelers to perform analyses and validation of urban dispersion models. An account for accessing the database may be requested by visiting https://ju2003-dpg.dpg.army.mil/. The back-up database site, https://ju2003-slc.dpg.army.mil/, may also be utilized when the main site is under maintenance. As of January 2006, there were over 140 database users from 25 states and 6 countries (Halvorson et al, 2006). 


\subsection{Organization}

The Joint Urban 2003 field study was a major effort, bringing together over 150 scientists, engineers, technicians and students from over 20 U.S. and foreign organizations to accomplish the study objectives. Participating organizations included six from the U.S. Department of Defense, five U.S. Department of Energy and Homeland Security national laboratories, two U.S. National Oceanic and Atmospheric Administration laboratories, eight U.S. universities, and other U.S. federal agencies and private companies. The U.S. organizations participating were

Department of Defense:

- Defense Threat Reduction Agency (DTRA)

- Army Research Laboratory (ARL)

- Army Research Office (ARO)

- Edgewood Chemical Biological Center (ECBC)

- Dugway Proving Ground (DPG)

- Defense Advanced Research Projects Agency (DARPA)

Departments of Homeland Security \& Energy:

- Argonne National Laboratory (ANL)

- Los Alamos National Laboratory (LANL)

- Lawrence Berkley National Laboratory (LBNL)

- Lawrence Livermore National Laboratory (LLNL)

- Pacific Northwest National Laboratory (PNNL)

National Oceanic and Atmospheric Administration:

- Air Resources Laboratory - Field Research Division (ARLFRD)

- Air Resources Laboratory - Atmospheric Turbulence and Diffusion Division (ATDD)
- Department of Transportation - Volpe Center

- Center for Disease Control/National Institute for Occupational Safety and Health (CDC/NIOSH)

- National Severe Storms Laboratory (NSSL)

Universities:

- Arizona State University (ASU)

- Central Florida University (CFU)

- Texas Tech University (TTU)

- Indiana University (IU)

- University of Houston (UH)

- University of Oklahoma (OU)

- University of Utah (UU)

- Washington State University (WSU)

State of Oklahoma:

- Oklahoma Climatological Survey (OCS)

- Department of Environmental Quality (DEQ)

Private Companies:

- Northrop Grumman Information Technology

- $\quad$ ITT Industries, Advanced Engineering \& Sciences

- Maccini Construction Company

- Allied Steel Construction Company

Other Federal Organizations:

Foreign participants were the United Kingdom Defense Science and Technology Laboratory (DSTL) and the Defense Research and Development Canada who participated in Joint Urban 2003 under the auspices of the U.S. Department of Defense Technical Panel 9 (TP9) of The Technical Cooperation Program (TTCP) Chemical, Biological and Radiological Defense (CBD) Group. Appendix B lists the study participants.

The Joint Urban 2003 lead scientist was Jerry Allwine (PNNL) who oversaw study design, logistical arrangements and field operations with the help of Joe Shinn (LLNL), Marty Leach (LLNL), Ray Hosker (ATDD), Leo Stockham (Northrop Grumman Information Technology [NGIT]) and Jim Bowers (DPG). Planning for Joint Urban 2003 was very extensive and began nearly two years prior to conducting the 
study in July 2003. As part of the planning, preliminary meteorological studies were conducted during the summer of 2002 to help determine the tracer release locations and the tracer sampler locations based on the predominant wind directions. Historically, the winds in OKC during July are predominantly from the south during both night and day, and this pattern was confirmed during the preliminary meteorological studies.

Further refinement of the tracer sampling network during the design phases of Joint Urban 2003 was accomplished using results from wind tunnel studies performed by the Meteorological Institute, University of Hamburg (Leitl et al, 2003), and from preliminary modeling studies performed by LLNL and CFD Research Corporation, Huntsville, Alabama (Coirier and Reich, 2003). These reports are available from the Dugway Proving Ground database website. The design-phase wind tunnel and modeling studies were very useful in finalizing the locations and sampling intervals of the tracer samplers. 


\subsection{Study Overview}

The Joint Urban 2003 study fielded many instruments in OKC and the surrounding area for the outdoor dispersion component of the study. Instrumentation from the indoor component that investigated the exchange of material into and within buildings will not be presented here. Details about instruments for the indoor component may be found on the DPG database site. Outdoor instruments consisted of tracer samplers, tracer analyzers, sonic anemometers, meteorological stations, and a variety of remote sensing instruments. Additionally, the Oklahoma Climatological Survey collected meteorological data from its Oklahoma Mesonet. The following list summarizes all the instrumentation, categorized by instrument type. Instruments that operated continuously throughout the study are labeled "(Cont)" below, while instruments that were only operational during the IOPs are marked with "(IOP).”

- 194 tracer bag samplers (IOP)

$\begin{array}{lll}\text { o } & 134 \text { ARLFRD } & \text { o } 16 \text { Volpe } \\ \text { o } & 44 \text { LLNL } & \end{array}$

- 25 fast-response tracer analyzers (IOP) o 10 ARLFRD 05 ITT o 10 LLNL

- 1 WSU seven-level tracer profile system (IOP)

- airborne remote sensing tracer instruments and met sensors (IOP) $\begin{array}{ll}0 & \begin{array}{l}\text { ECBC } \\ \text { helicopter }\end{array}\end{array}$

- 2 lidars (IOP)
o ARL
o ASU

- 3 radiosondes (IOP)

o ANL

o PNNL

o ARL

- 2 tethersondes (IOP)
o DPG
o UU

- 7 2-D sonic anemometers (IOP)
o 5 LANL
o 2 Volpe

- 33 PNNL temperature sensors (Cont)
- 106 3-D sonic anemometers (Cont)
o 12 ARL
- $9 \mathrm{IU}$
o 4 ASU
o 6 LANL
o 8 ATDD
- 8 LLNL
o 20 DPG
o $10 \mathrm{OU}$
o 7 DSTL $^{(\mathrm{d})}$
o $11 \mathrm{UU}$
o $11 \mathrm{ITT}^{(\mathrm{d})}$

- 8 surface energy stations (Cont)
o 1 ASU
o $4 \mathrm{IU}$
o 3 ATDD

- 29 surface meteorological stations (Cont)
o 15 DPG
- 3 NWS $^{(\mathrm{a})} \mathrm{ASOS}^{(\mathrm{b})}$
o 5 PNNL
o 6 OK Mesonet

- 9 sodars (Cont)
o 4 ANL
o $1 \mathrm{UH}$
o 1 ARLFRD
o 1 PNNL
o 1 DPG
o $1 \mathrm{UU}$

- 4 weather stations (Cont)

o NWS WSR-88D

- 4 radar profilers (3 with RASS) (Cont)
o ANL
o PNNL
O OU
o DPG FM-CW ${ }^{(\mathrm{c})}$

- Traffic study, mobile air temperatures, microbarograph study (Cont)

- 3 ceilometers (Cont)

(a) NWS = National Weather Service

(b) ASOS = Automated Surface Observing System

(c) FM-CW = Frequency Modulated Continuous Wave Radar Profiler: gives high temporal and spatial resolution of vertical structure, specifically mixing depth. Does not give winds.

(d) These instruments collected data only during the IOPs 
A complete listing of the instrumentation deployed by each participating institution, along with coordinates and maps of their locations, can be found in Appendix A to this document. Additionally, the Dugway Proving Ground database contains geographic information system (GIS) shapefiles that may be downloaded and viewed with GIS software. These shapefiles were created with ArcView version 9.0. A free GIS data viewer, called ArcExplorer, may be downloaded from the ESRI website (http://www.esri.com/software/arcexplorer/download.html) for viewing the instrument locations.

The majority of the meteorological and tracer instruments were sited within or near the CBD with some tracer and meteorological measurements extending out to approximately six kilometers from the CBD. Figure 4.1 presents an overview of the meteorological instruments covering the study region. As stated in the Scientific Objectives section, this field study also aimed to study scales-of-motion as small as within a single city block. Therefore, a single street canyon along Park Avenue between Robinson and Broadway Avenues was selected for a large number of surface and profile meteorological instruments. Figure 4.2 shows the instrumentation that was deployed in the Park Avenue street canyon.

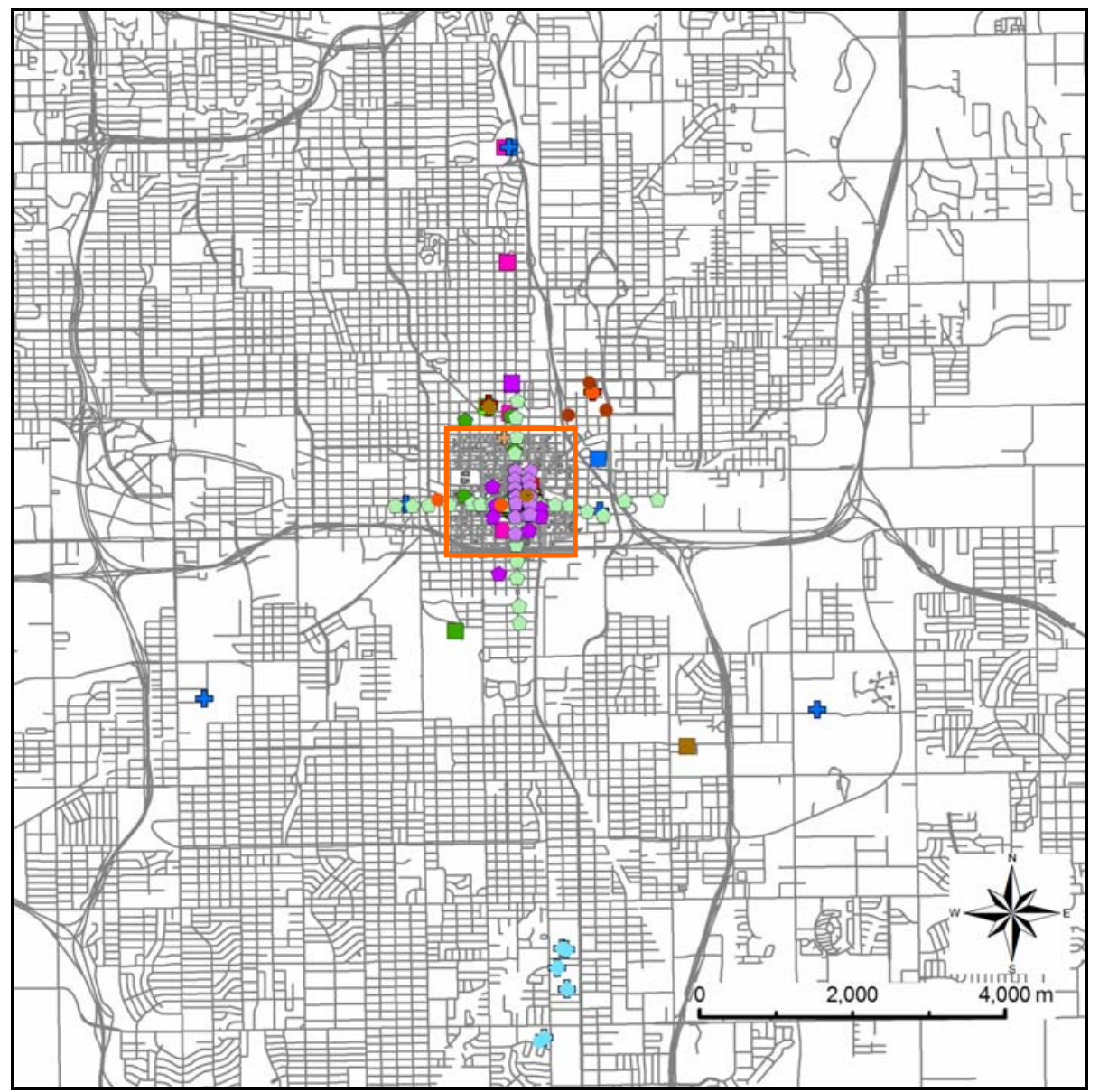

Figure 4.1. Overview of Meteorological Measurement Sites Around OKC. The orange rectangle encloses the central business district. The symbols indicate coverage of all of the meteorological instruments. For location information on specific instruments, see Appendix A. 


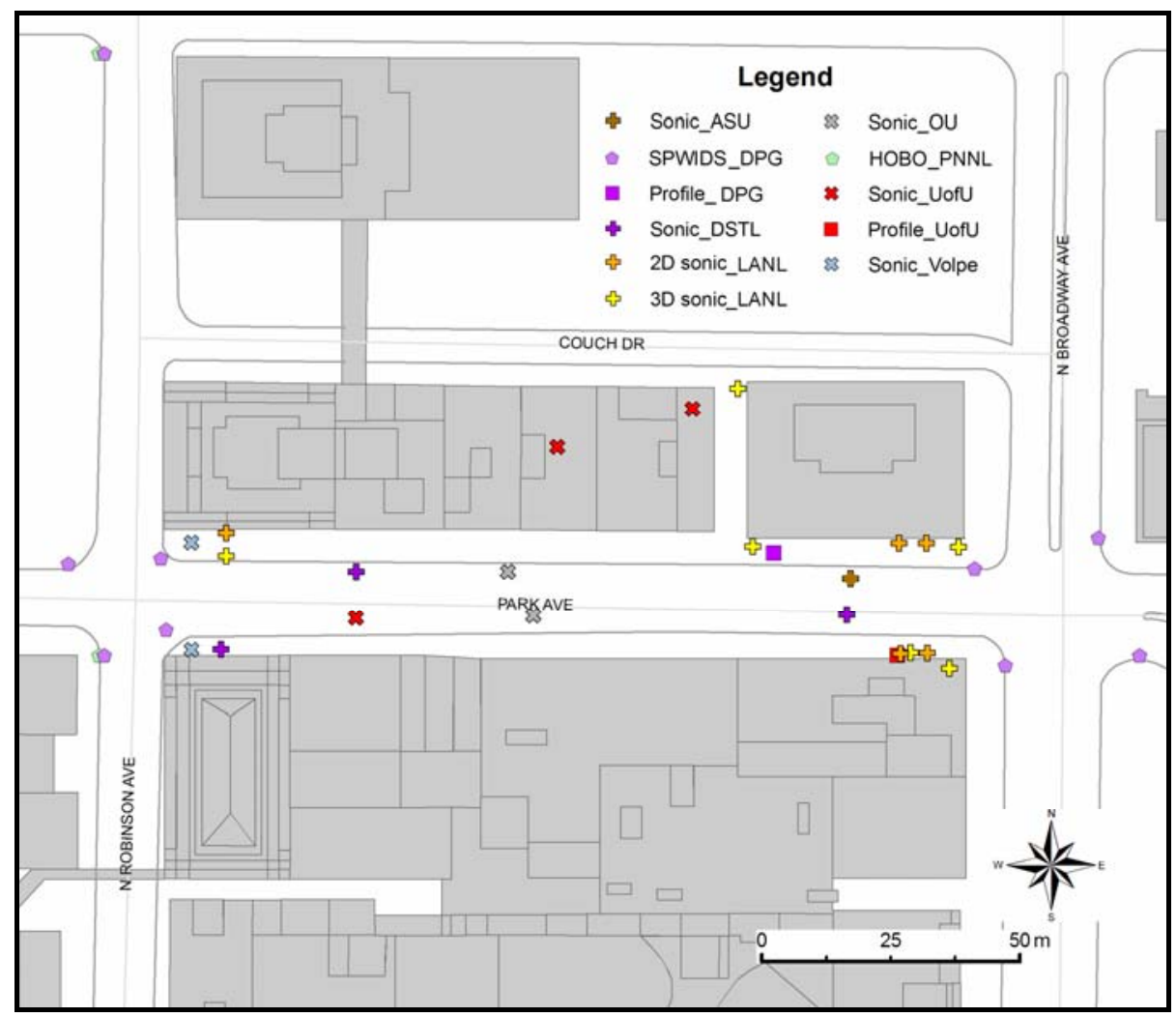

Figure 4.2. Instruments that were Located in the Park Ave Street Canyon. The instruments that appear in this figure were deployed at these locations for each IOP. Many of these instruments also remained at the measurement locations for the duration of the field campaign. (The two profile sites, the 2D sonics from LANL, and the sonics from Volpe were only operational during IOPs.)

Sulfur hexafluoride tracer was released as puffs and continuous releases from one of three release locations (Figure 4.3) during the 10 main IOPs. The release location was chosen dependent on the wind direction and building configuration. The "Westin" release was used when the winds were expected from the S through SSE and the "Botanical” release was used when the winds were expected from the S through SSW. During the first IOP, there were busses parked at the Westin release location, so the release was conducted across the street, and is indicated as Westin East. The "Park" release was used when studying the Park Avenue urban street canyon effects in more detail. A "mini" IOP (labeled " $5 \mathrm{a}$ " in Tables 4.1. and 4.2) was conducted when the expected wind direction was from the SW. The full suite of tracer instruments was not deployed for the mini IOP; however, the 7-level tracer profiler collected tracer data. The release location during each IOP is identified in Figure 4.3 and Table 4.1.

The first six IOPs occurred during daylight hours, typically beginning at 0900 CDT and ending 8 hours later at $1700 \mathrm{CDT}$. The last four IOPs occurred during the night, typically beginning at $2300 \mathrm{CDT}$ and ending at 0700 CDT. During each IOP typically seven near ground-level point releases occurred three continuous releases of $1 / 2$ hour duration and four instantaneous releases where balloons filled with tracer were popped. Table 4.2 summarizes the times and rates of the tracer releases. 


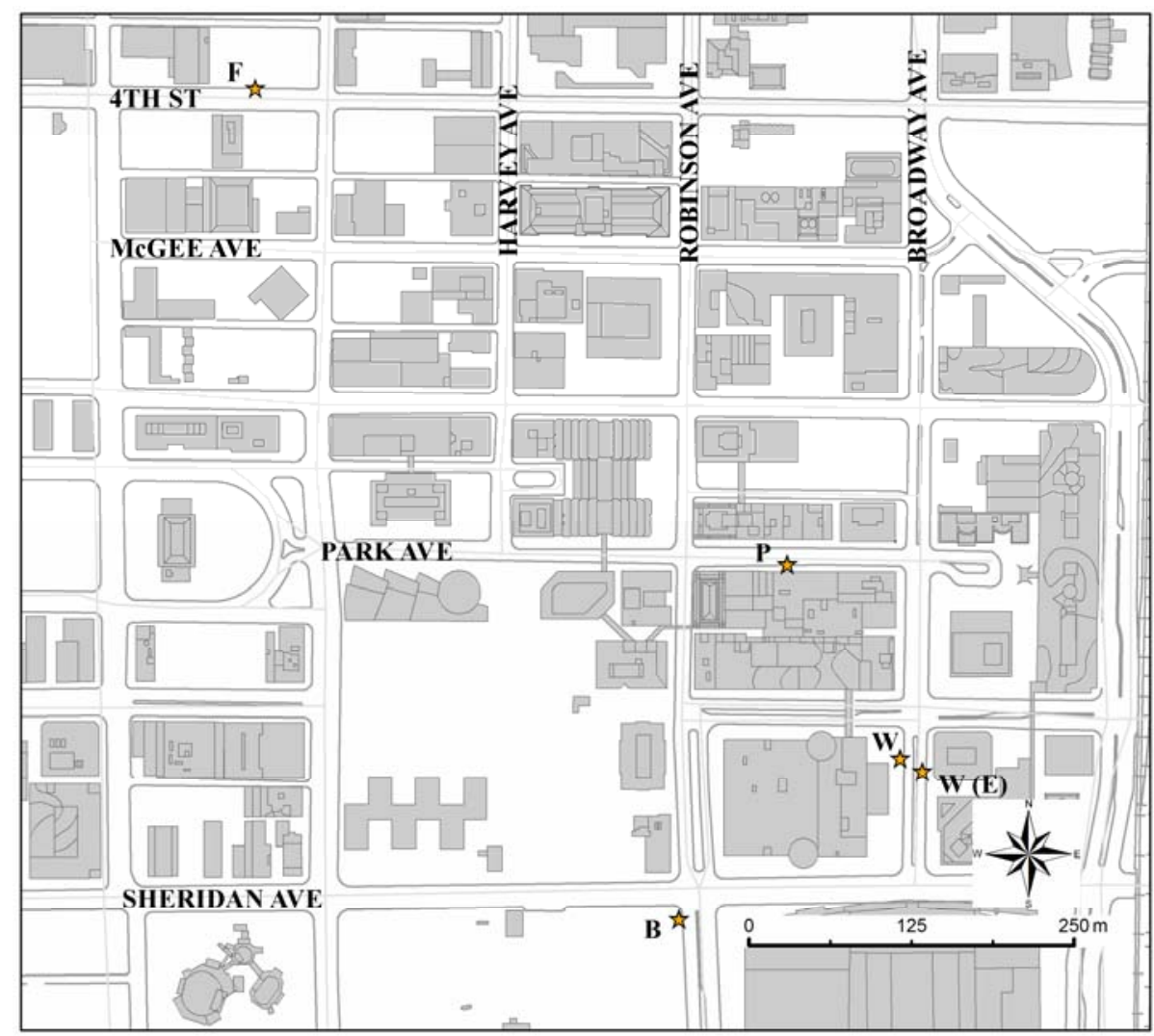

Figure 4.3. Tracer Release Locations. $\mathrm{W}(\mathrm{E})=$ Westin East, $\mathrm{W}=$ Westin, $\mathrm{B}=$ Botanical, $\mathrm{P}=$ Park, and $\mathrm{F}=$ Fourth

Table 4.1. Summary of Intensive Observation Periods (IOPs). DOY = day of year, Release Locations are $\mathrm{W}(\mathrm{E})=$ Westin East, $\mathrm{W}=$ Westin, $\mathrm{B}=$ Botanical, $\mathrm{P}=$ Park, and $\mathrm{F}=$ Fourth. See Fig 4.3 for a map with release locations.

\begin{tabular}{|c|c|c|c|c|c|c|l||}
\hline $\begin{array}{c}\text { IOP } \\
\#\end{array}$ & $\begin{array}{c}\text { Begin Date } \\
\mathbf{2 0 0 3}\end{array}$ & $\begin{array}{c}\text { Begin } \\
\text { DOY }\end{array}$ & $\begin{array}{c}\text { Beg / End } \\
\text { Time (CDT) }\end{array}$ & $\begin{array}{c}\text { Day/ } \\
\text { Night }\end{array}$ & $\begin{array}{c}\text { In- } \\
\text { door }\end{array}$ & $\begin{array}{c}\text { Release } \\
\text { Location }\end{array}$ & $\begin{array}{c}\text { \# Releases; Puff (P)/ } \\
\text { Continuous (C) }\end{array}$ \\
\hline 1 & $6 / 29-$ Sun & 180 & $09 / 15^{(a)}$ & D & & W (E) & 8; P,P,P,P,P,P,C,C \\
\hline 2 & $7 / 02-$ Wed & 183 & $09 / 17$ & D & & W & $7 ;$ P,P,P,P,C,C,C \\
\hline 3 & $7 / 07-$ Mon & 188 & $09 / 17$ & D & & B & 7; P,P,P,P,C,C,C \\
\hline 4 & $7 / 09-$ Wed & 190 & $09 / 17$ & D & I & B & 6; P,P,P,C,C,C \\
\hline 5 & $7 / 13-$ Sun & 194 & $09 / 17$ & D & I & B & 7; C,C,C,P,P,P,P \\
\hline $5 a$ & $7 / 15-$ Tue & 196 & $12 / 14$ & D & & F & 3; C,C,C \\
\hline 6 & $7 / 16-$ Wed & 197 & $09 / 17$ & D & I & B & 7; C,C,C,P,P,P,P \\
\hline 7 & $7 / 18-$ Fri & 199 & $23 / 07$ & N & I & B & 7; C,C,C,P,P,P,P \\
\hline 8 & $7 / 24-$ Thu & 205 & $23 / 07$ & N & & W & 7; C,C,C,P,P,P,P \\
\hline 9 & $7 / 26-$ Sat & 207 & $23 / 07$ & N & & P & 7; C,C,C,P,P,P,P \\
\hline 10 & $7 / 28-$ Mon & 209 & $21 / 04^{(a)}$ & N & & P & 6; C,C,C,P,P,P \\
\hline (a) Stopped early because of wind shift off sampling grid. & & \\
\hline
\end{tabular}


Meteorological conditions during the July 2003 study period are summarized in Figure 4.4. The period of each IOP is identified, showing the wind directions primarily from the SSW through SSE during IOPs. The $\mathrm{SF}_{6}$ tracer samplers and analyzers were deployed in different configurations depending on the release location. Figure 4.5 shows all the sampler configurations used for all the IOPs. More detailed images of tracer instrumentation deployed by each group during each IOP can be found in Appendix A.

Table 4.2. Summary of IOP Tracer Release Rates and Times.

\begin{tabular}{|c|c|c|c|c|}
\hline IOP & Date & $\begin{array}{c}\text { Release } \\
\text { Type }\end{array}$ & $\begin{array}{c}\text { Start } \\
\text { (CDT) }\end{array}$ & $\begin{array}{l}\text { Release } \\
\text { Amount }\end{array}$ \\
\hline \multirow[t]{8}{*}{1} & $6 / 29 / 03$ & Puff & 0900 & 1000 \\
\hline & & Puff & 0910 & 1003 \\
\hline & & Puff & 0920 & 1000 \\
\hline & & Puff & 0930 & 1000 \\
\hline & & Puff & 0945 & 500 \\
\hline & & Puff & 1000 & 508 \\
\hline & & 30-Min & 1100 & 4.9 \\
\hline & & 30-Min & 1300 & 4.8 \\
\hline \multirow[t]{7}{*}{2} & $7 / 2 / 03$ & Puff & 0900 & 1001 \\
\hline & & Puff & 0920 & 1010 \\
\hline & & Puff & 0940 & 1000 \\
\hline & & Puff & 1000 & 1041 \\
\hline & & 30-Min & 1100 & 5.0 \\
\hline & & 30-Min & 1300 & 5.0 \\
\hline & & 30-Min & 1500 & 5.0 \\
\hline \multirow[t]{7}{*}{3} & 7/7/03 & Puff & 0900 & 1000 \\
\hline & & Puff & 0920 & 1005 \\
\hline & & Puff & 0940 & 1000 \\
\hline & & Puff & 1000 & 1004 \\
\hline & & 30-Min & 1100 & 5.0 \\
\hline & & 30-Min & 1300 & 3.0 \\
\hline & & 30-Min & 1500 & 3.0 \\
\hline \multirow[t]{6}{*}{4} & 7/9/03 & Puff & 0900 & 996 \\
\hline & & Puff & 0920 & 1002 \\
\hline & & Puff & 0940 & 504 \\
\hline & & 30-Min & 1100 & 3.1 \\
\hline & & 30-Min & 1300 & 3.0 \\
\hline & & 30-Min & 1500 & 3.0 \\
\hline \multirow[t]{7}{*}{5} & $7 / 13 / 03$ & 30-Min & 0900 & 2.2 \\
\hline & & 30-Min & 1100 & 3.0 \\
\hline & & 30-Min & 1300 & 3.1 \\
\hline & & Puff & 1500 & 499 \\
\hline & & Puff & 1520 & 500 \\
\hline & & Puff & 1540 & 500 \\
\hline & & Puff & 1600 & 500 \\
\hline \multirow[t]{3}{*}{$5 a$} & 7/15/03 & 20-Min & 1200 & 8.0 \\
\hline & & 20-Min & 1230 & 5.0 \\
\hline & & 20-Min & 1300 & 3.0 \\
\hline
\end{tabular}

\begin{tabular}{|c|c|c|c|c|}
\hline IOP & Date & $\begin{array}{c}\text { Release } \\
\text { Type } \\
\end{array}$ & $\begin{array}{c}\text { Start } \\
\text { (CDT) }\end{array}$ & $\begin{array}{l}\text { Release } \\
\text { Amount }\end{array}$ \\
\hline \multirow[t]{7}{*}{6} & $7 / 16 / 03$ & 30-Min & 0900 & 3.0 \\
\hline & & 30-Min & 1100 & 3.2 \\
\hline & & 30-Min & 1300 & 3.0 \\
\hline & & Puff & 1500 & 498 \\
\hline & & Puff & 1520 & 499 \\
\hline & & Puff & 1540 & 510 \\
\hline & & Puff & 1600 & 500 \\
\hline \multirow[t]{7}{*}{7} & 7/18/03 & 30-Min & 2300 & 3.0 \\
\hline & & 30-Min & 0100 & 2.0 \\
\hline & & 30-Min & 0300 & 2.0 \\
\hline & & Puff & 0500 & 303 \\
\hline & & Puff & 0520 & 300 \\
\hline & & Puff & 0540 & 304 \\
\hline & & Puff & 0600 & 298 \\
\hline \multirow[t]{7}{*}{8} & 7/24/03 & 30-Min & 2300 & 3.1 \\
\hline & & 30-Min & 0100 & 3.0 \\
\hline & & 30-Min & 0300 & 3.0 \\
\hline & & Puff & 0500 & 500 \\
\hline & & Puff & 0520 & 500 \\
\hline & & Puff & 0540 & 300 \\
\hline & & Puff & 0600 & 305 \\
\hline \multirow[t]{7}{*}{9} & 7/26/03 & 30-Min & 2300 & 2.0 \\
\hline & & 30-Min & 0100 & 2.0 \\
\hline & & 30-Min & 0300 & 2.1 \\
\hline & & Puff & 0500 & 300 \\
\hline & & Puff & 0520 & 300 \\
\hline & & Puff & 0540 & 300 \\
\hline & & Puff & 0600 & 300 \\
\hline \multirow[t]{9}{*}{10} & 7/28/03 & 30-Min & 2100 & 2.2 \\
\hline & & 30-Min & 2300 & 1.9 \\
\hline & & 30-Min & 0100 & 2.2 \\
\hline & & Puff & 0300 & 300 \\
\hline & & Puff & 0320 & 300 \\
\hline & & Puff & 0340 & 300 \\
\hline & & & & \\
\hline & & & & \\
\hline & & & & \\
\hline
\end{tabular}




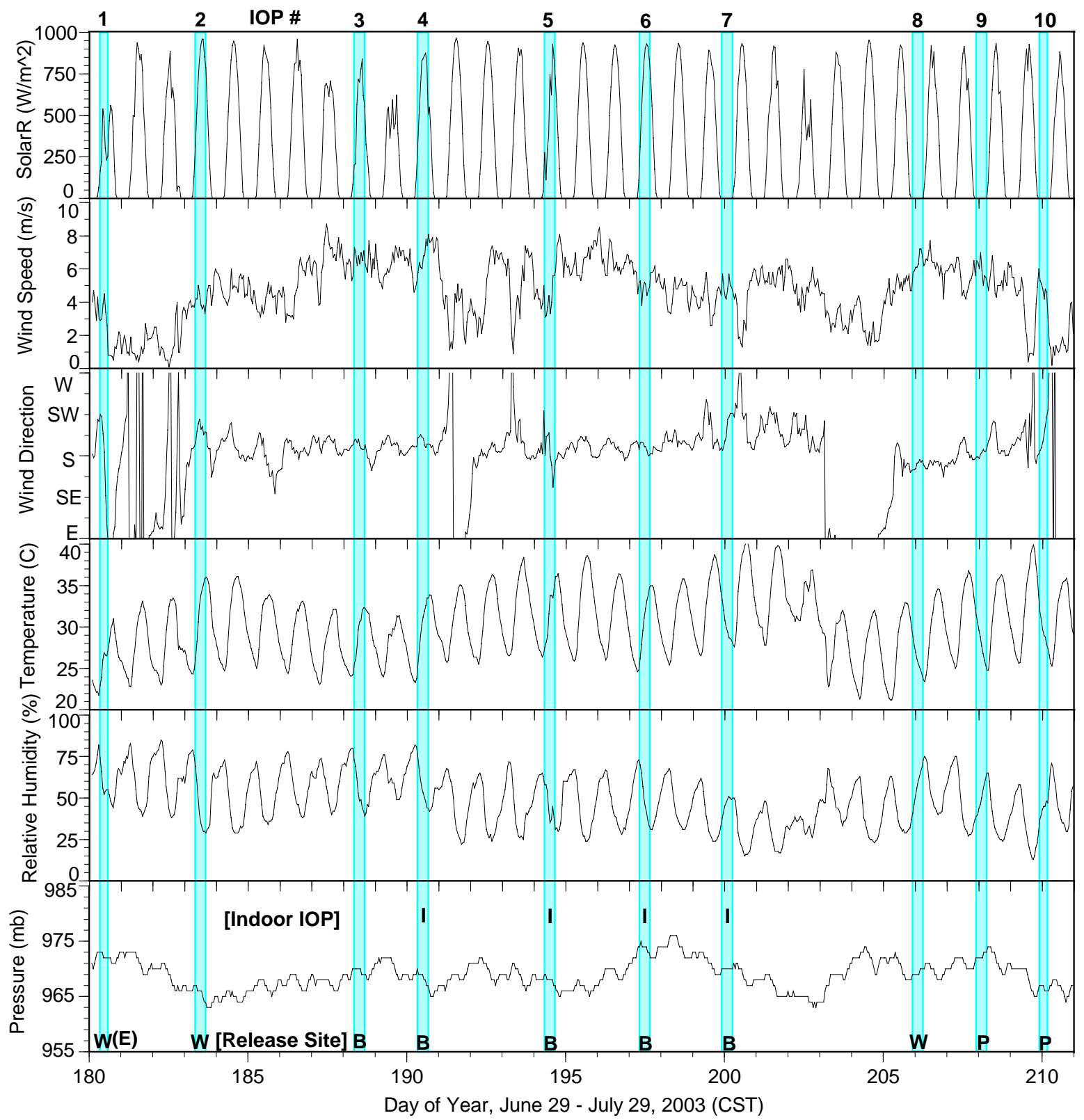

Figure 4.4. Hourly Averaged Meteorological Conditions for July 2003 Measured at $3 \mathrm{~m}$ Above the Rooftop on a 42-m-high Building with Unobstructed Exposure to the Winds. The weather station was located on St. Anthony's hospital (NW $10^{\text {th }} \&$ Dewey) approximately $1 \frac{1 / 2}{\mathrm{~km}}$ NW of downtown OKC. The atmospheric pressure is from a weather station on the rooftop of the 34-m-high Civic Center Music Hall (Colcord \& Lee) just west of downtown OKC. The blue lines indicate the times of the IOPs during which tracers were released. The labels "W (E)," "W," "B," and "P" (Westin East, Westin, Botanical and Park) identify the tracer release location for each IOP (see Figure 4.3 and Table 4.1). 
The release locations and "indoor study" IOPs are also identified in Figure 4.4. An indoor component to this study was conducted during IOPs 4-7. The four buildings studied as part of the indoor component of Joint Urban 2003 were located near the intersections of Park \& Broadway and McGee \& Harvey. During indoor IOPs the release location was chosen such that the tracer plume would move in the direction of the indoor study buildings based on the forecast wind directions. The Joint Urban 2003 database website contains information and data from the indoor study; however, the indoor instrumentation will not be described in this report. All of the outdoor tracer sampler and analyzer instrumentation deployed during this study are presented in Figure 4.5.

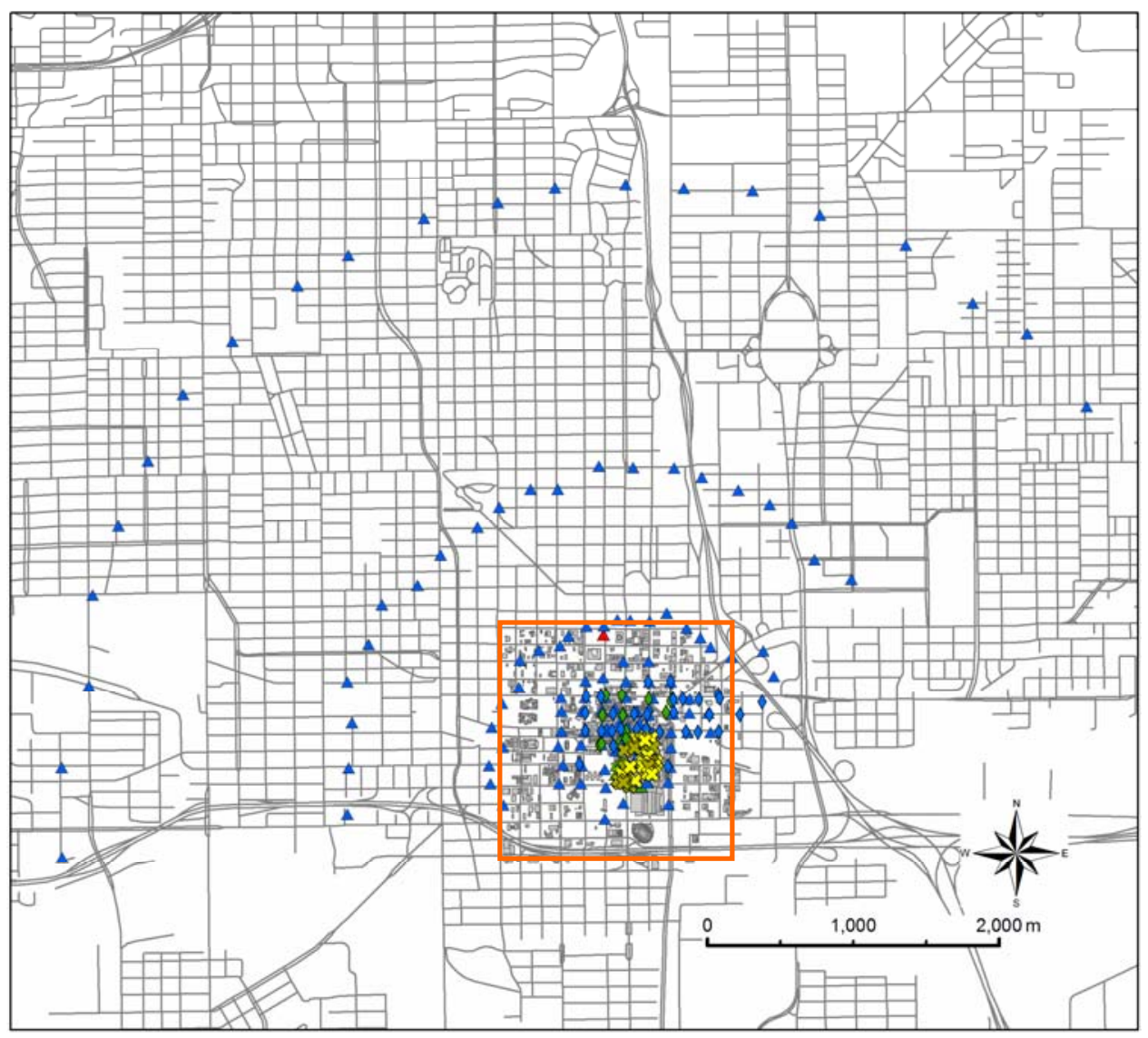

Figure 4.5. Overview of Tracer Sampler and Analyzer Instrument Locations. The orange box encloses the central business district of OKC. For location information on specific instruments, see Appendix A. 


\subsection{References}

Allwine, K.J., M.J. Leach, L.W. Stockham, J.S. Shinn, R.P. Hosker, J.F. Bowers, and J.C. Pace. 2004: Overview of Joint Urban 2003 - an atmospheric dispersion study in Oklahoma City. Preprints, $84^{\text {th }}$ AMS Annual Meeting, Seattle, WA, Amer. Meteor. Soc., J7.1.

Burrows, D., and E. Hendricks. May 2004. Final Report Joint Urban 2003 Atmospheric Dispersion Study. ITT Industries.

Clawson, K.L., R.G. Carter, D.J. Lacroix, C.A. Biltoft, N.F. Hukari, R.C. Johnson, J.D. Rich, S.A. Beard, and T. Strong. May 2005. Joint Urban 2003 (JU03) SF 6 Atmospheric Tracer Field Tests. NOAA Technical Memorandum OAR ARL-254.

Coirier, W.J., and A.J. Reich. 2003: Oklahoma City High-Resolution Dispersion Simulation. CFDRC Report 8520/1. Huntsville, AL. 23 pp.

Halvorson, S.F., D.P. Storwold, E.M. Vernon. 2006: Joint Urban 2003 Database/Web Design. Preprints, $86^{\text {th }}$ AMS Annual Meeting, Atlanta, GA, Amer. Meteor. Soc., 5.9a

Leach, M.J., October 2005: Final Report for the Joint Urban 2003 Atmospheric Dispersion Study in Oklahoma City: Lawrence Livermore National Laboratory Participation. LLNL Report No. UCRLTR-216437, Lawrence Livermore National Laboratory, Livermore, California.

Leitl, B., F. Pascheke, and M. Schatzmann. Aug. 2003: Final Report Phase I: Generation of Wind Tunnel Data Sets in Support of the Joint Urban 2003 Atmospheric Dispersion Study, Oklahoma City, July 2003. Meteorological Institute, Hamburg University. 


\section{Appendix A}

This section contains information concerning the locations of all of the instrumentation deployed during the Joint Urban 2003 field campaign. The instruments are presented in alphabetical order by the institution responsible for the instruments. The instrument coordinates are presented in both geodetic coordinates (latitude and longitude) and Universal Transverse Mercator (UTM) coordinates in meters. Latitude values are north of the equator and longitude values are west of the prime meridian. UTM coordinates are generally projected to zone $14 \mathrm{~N}$ with the 1983 North American Datum. The exception to this is the Tulsa radar site, which was in zone $15 \mathrm{~N}$.

The instrument coordinates presented in this section are a result of extensive investigation. It was discovered that the instrument positions that were provided with the data were not always an accurate representation of the true instrument location. Therefore, each instrument location was examined carefully using a variety of information sources, including instrument ReadMe files, instrument photos, and aerial images from the United States Geological Survey (USGS) and Google Earth. This information was used to position each instrument within the urban landscape, which was defined primarily by the building shapefile (Dr. May Yuan, OU Dept. of Geography). Curblines were also available for the central business district, and streetlines were available for the whole of Oklahoma City. These shapefiles were not as reliable as the building shapefile, and were used with caution. The coordinates presented in this document are the definitive positions of the instruments with respect to the GIS-defined urban landscape. When there are discrepancies between the information provided with the data from the Dugway Proving Ground database site and the tables in this section, the information in this document should be used.

\section{A.1 Argonne National Laboratory}

The Argonne National Laboratory deployed profile instrumentation at four sites. Table A.1 presents the coordinates of the instrumentation at each of these sites, while Figures A.1 and A.2 show the locations on a map. Data collected from ANL can also be found at their website: http://www.atmos.anl.gov/OKC/.

Table A.1. ANL Instrument Locations

\begin{tabular}{|l|l|r|r|r|r||}
\hline \hline Instrument & Location Description & Latitude & Longitude & Easting & Northing \\
\hline \hline profiler/RASS & First Christian Church & 35.50999 & 97.51726 & 634463 & 3930612 \\
\hline minisodar & First Christian Church & 35.50999 & 97.51726 & 634463 & 3930612 \\
\hline rawindsonde & First Christian Church & 35.50999 & 97.51726 & 634463 & 3930612 \\
\hline minisodar & Botanical Gardens & 35.46474 & 97.51822 & 634451 & 3925592 \\
\hline sodar & Goodholm Park & 35.49634 & 97.51713 & 634497 & 3929098 \\
\hline minisodar & $10^{\text {th }}$ and Harvey & 35.47866 & 97.51707 & 634532 & 3927137 \\
\hline \hline
\end{tabular}




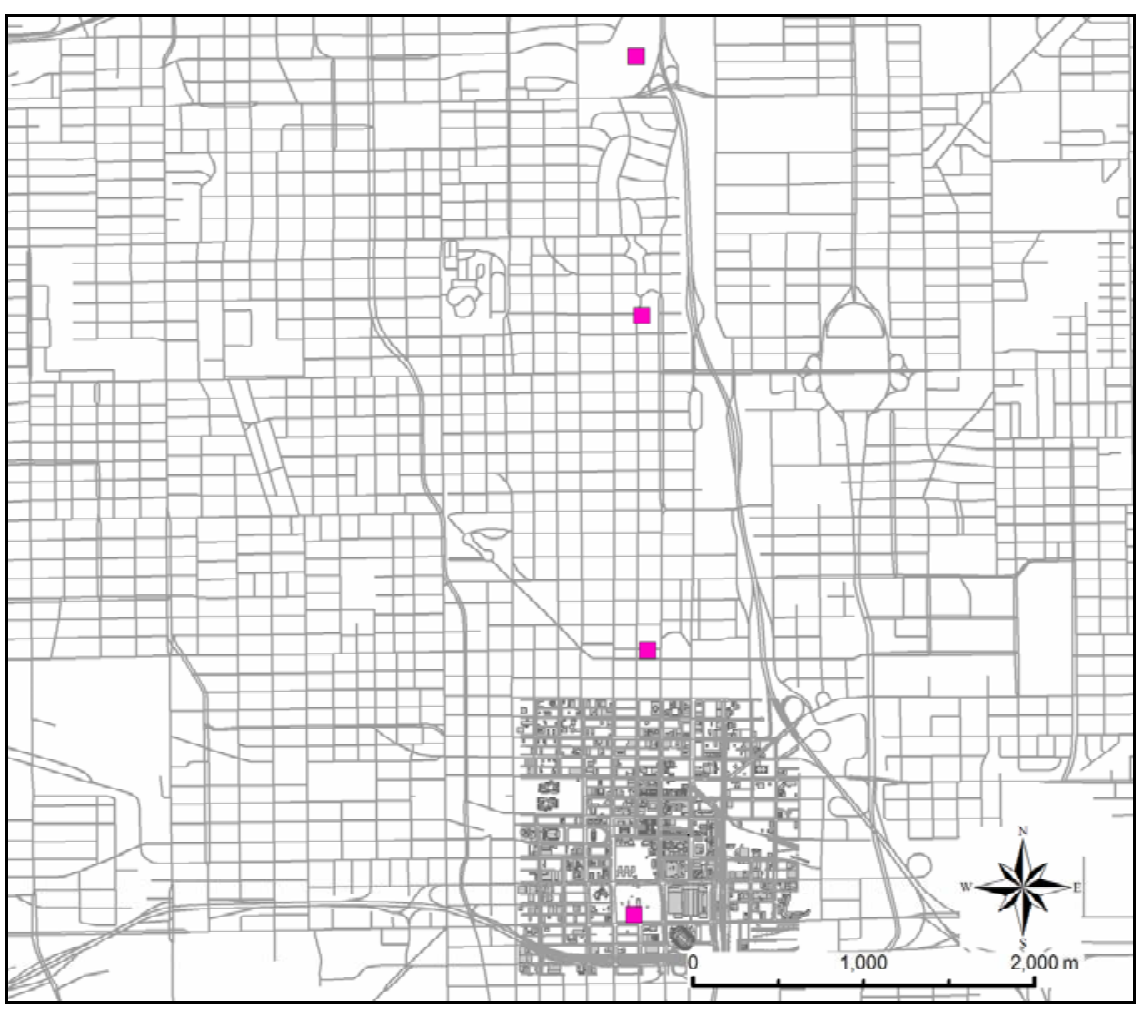

Figure A.1. Overview of ANL Instrument Locations 

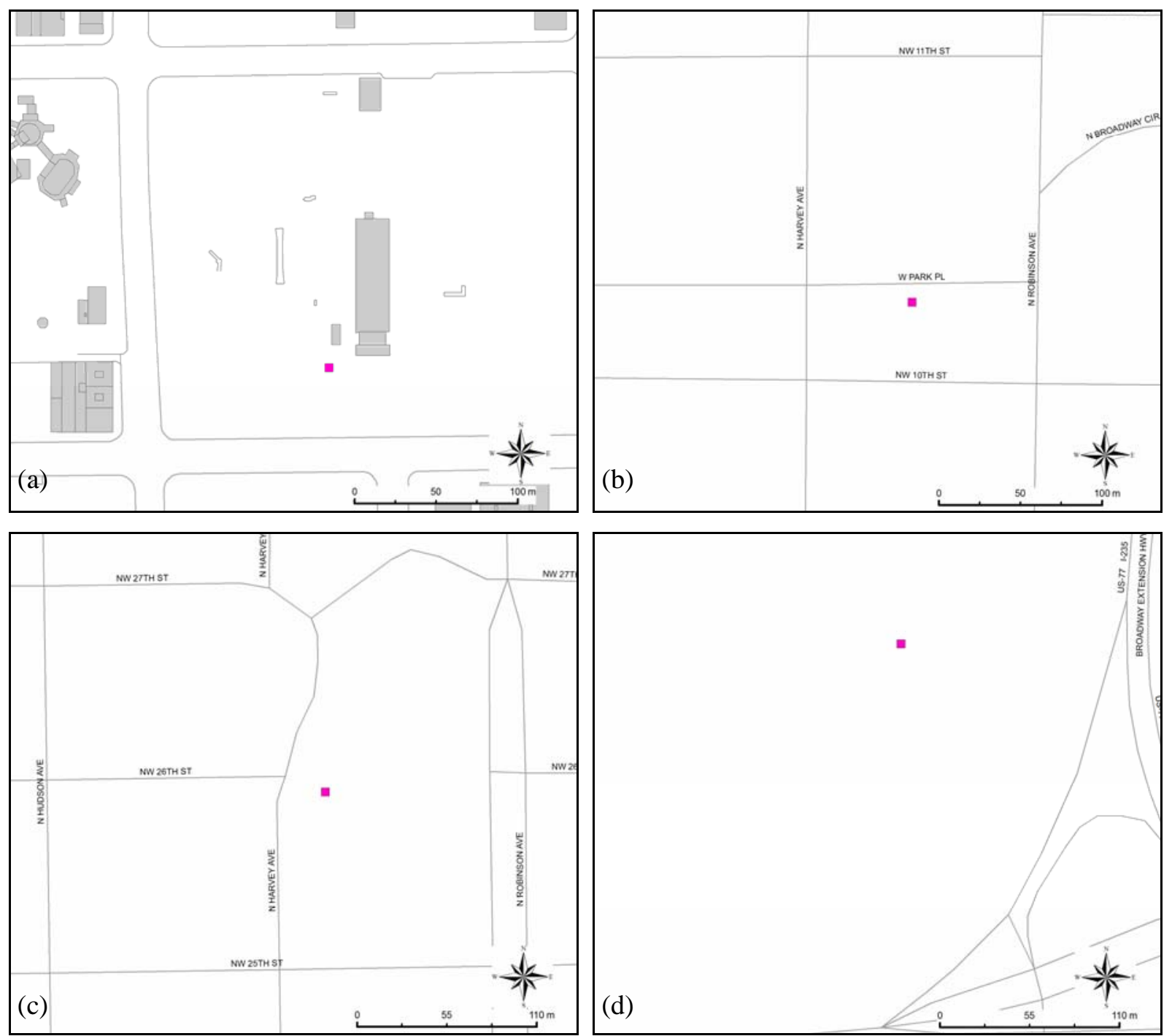

Figure A.2. ANL Instrument Locations: (a) Botanical, (b) $10^{\text {th }}$ and Harvey Site, (c) Goodholm Park, and (d) First Christian Church

\section{A.2 Army Research Laboratory}

The Army Research Laboratory deployed instrumentation at six separate sites around Oklahoma City. Five of these sites had towers with 3D sonic anemometers mounted at $10 \mathrm{~m}$ and $5 \mathrm{~m}$ above ground level, while two of the towers (numbered 2 and 3 in Table A.2) had an additional sonic anemometer at $2.5 \mathrm{~m}$ above ground level. The instrument coordinates are presented in Table A.2 and locations are shown in Figures A.3 and A.4. 
Table A.2. ARL Instrument Locations

\begin{tabular}{||l|l|c|c|c|c||}
\hline \hline Instrument & Location Description & Latitude & Longitude & Easting & Northing \\
\hline \hline Sonic tower 1 & SW 18th \& S Miller & 35.44529 & 97.56171 & 630536 & 3923376 \\
\hline Sonic tower 2 & $\begin{array}{l}\text { E Sheridan \& S Byers (near Bricktown } \\
\text { Ballpark) }\end{array}$ & 35.46684 & 97.50418 & 635721 & 3925844 \\
\hline Sonic tower 3 & 2300 SE 22nd. Park Maintenance & 35.44295 & 97.47329 & 638565 & 3923237 \\
\hline Sonic tower 4 & NW 36th \& Walker. First Christian Church & 35.50994 & 97.51657 & 634525 & 3930608 \\
\hline Sonic tower 5 & W Main \& N Klein & 35.46800 & 97.53217 & 633180 & 3925934 \\
\hline rawindsonde & NW 36th \& Walker. First Christian Church & 35.50994 & 97.51657 & 634525 & 3930608 \\
\hline $\begin{array}{l}\text { Lidar / } \\
\text { radiometer }\end{array}$ & $\begin{array}{l}\text { On parking garage at 655 Research Parkway } \\
{[\sim 10 \mathrm{~m} \text { agl] }}\end{array}$ & 35.47308 & 97.50443 & 635688 & 3926536 \\
\hline
\end{tabular}

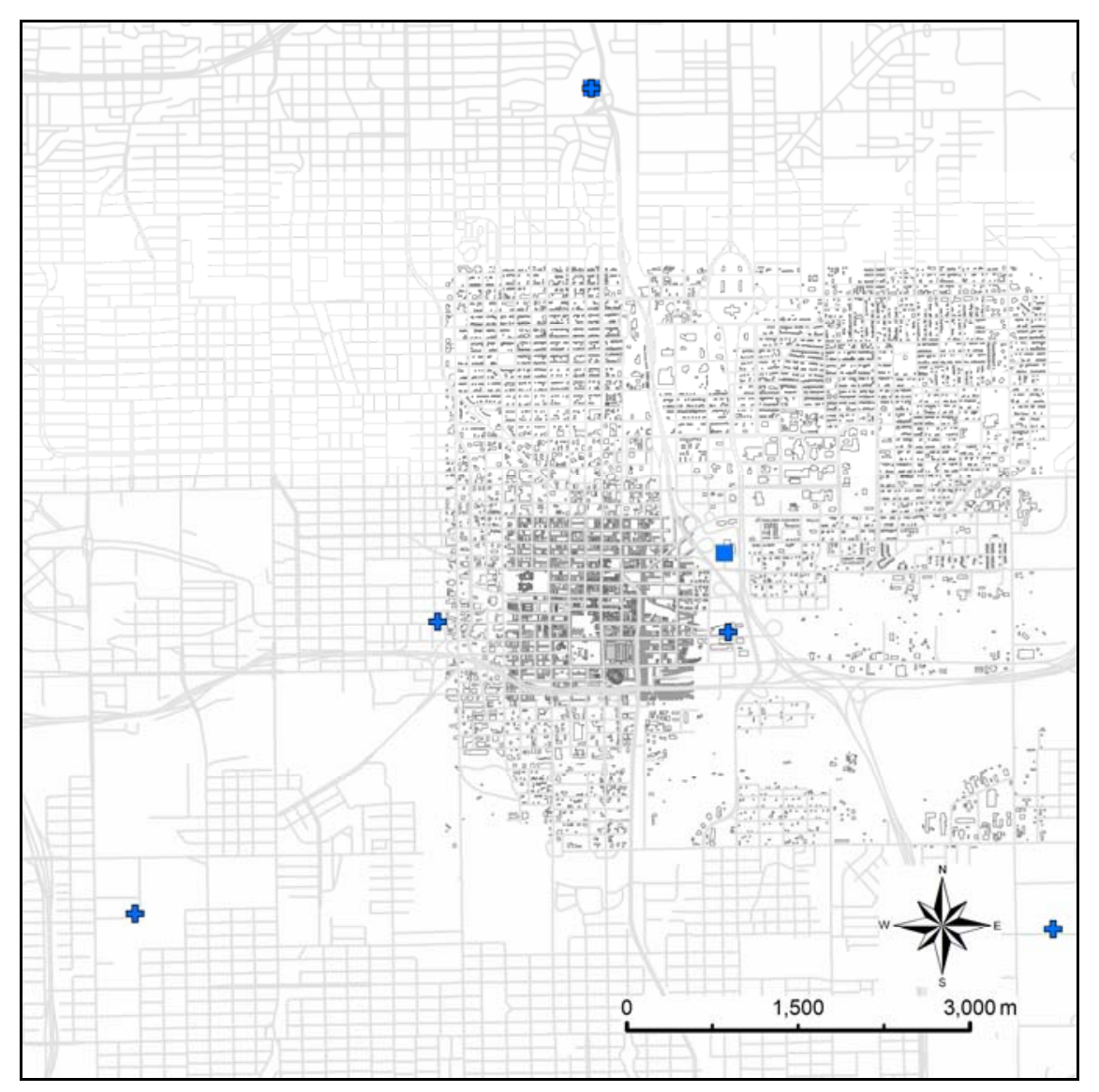

Figure A.3. Overview of ARL Instrument Locations 

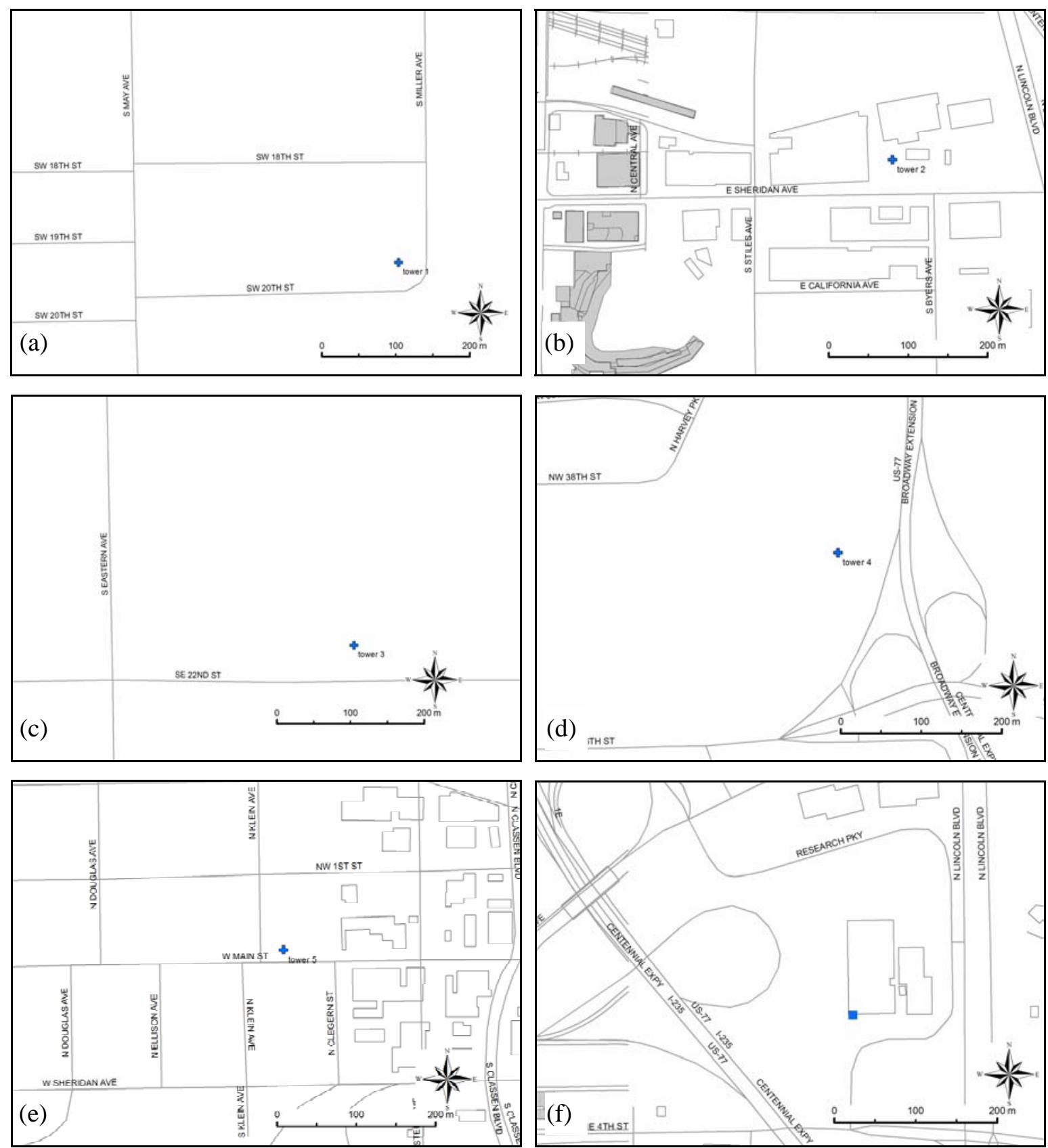

Figure A.4. ARL Instrument Locations for (a) Tower 1, (b) Tower 2, (c) Tower 3, (d) Tower 4 and Rawindsonde, (e) Tower 5, and (f) Lidar and Radiometer 


\section{A.3 NOAA Air Resources Laboratory-Field Research Division}

The NOAA Air Resources Laboratory Field Research Division deployed a large number of $\mathrm{SF}_{6}$ tracer samplers and analyzers throughout Oklahoma City. The tracer samplers, known as Programmable Integrating Gas Samplers (PIGS) and a newer version Super-PIGS (S-PIGS), were placed within the central business district and in 1-, 2-, and 4-km arcs from the central business district. The PIGS and SPIGS were deployed in different arrangements during each IOP, depending on the expected wind direction. The sampler positions used during this field study are presented in Table A.3 and in Figures A.5, A.6, and A.7. Trace Gas Analyzers (TGAs) measured instantaneous concentrations of $\mathrm{SF}_{6}$, and were deployed in one mobile and nine stationary vans in the central business district. The coordinates of the stationary vans during each IOP are presented in Table A.4 and the locations are shown in Figure A.8.

Additionally, the tracer dissemination for this field study was performed by ARLFRD. The tracer dissemination site consisted of a release tube (for continuous releases), a release balloon (for instantaneous releases), a 3D sonic anemometer, and a temperature/RH sensor. The coordinates of the five tracer release locations that were used during this field study are presented in Table A.5 and the locations are shown in Figure A.9. Finally, a sodar was deployed at the Oklahoma School of Science and Mathematics. The coordinates of this sodar are given in Table A.6 and the position is shown on a map in Figure A.10.

Table A.3. ARLFRD Tracer Sampler Instrument Locations

\begin{tabular}{|l|l|c|c|c|c|}
\hline Instrument & Location Description & Latitude & Longitude & Easting & Northing \\
\hline \hline$[003]$ & CBD - Reno \& Harvey & 35.46436 & 97.51795 & 634476 & 3925550 \\
\hline$[014]$ & CBD - Robinson between Reno \& Sheridan & 35.46532 & 97.51652 & 634604 & 3925659 \\
\hline$[017]$ & CBD - Santa Fe between Reno \& Sheridan & 35.46518 & 97.51312 & 634913 & 3925648 \\
\hline$[021]$ & CBD - Sheridan \& Walker & 35.46657 & 97.52136 & 634163 & 3925790 \\
\hline$[022]$ & CBD - Sheridan \& Hudson & 35.46656 & 97.51973 & 634311 & 3925792 \\
\hline$[023]$ & CBD - Sheridan between Hudson \& Robinson & 35.46630 & 97.51783 & 634484 & 3925765 \\
\hline$[024]$ & CBD - Sheridan \& Robinson & 35.46655 & 97.51657 & 634598 & 3925795 \\
\hline$[025]$ & CBD - Sheridan between Robinson \& Broadway & 35.46655 & 97.51530 & 634713 & 3925797 \\
\hline$[026]$ & CBD - Sheridan \& Broadway & 35.46656 & 97.51469 & 634768 & 3925798 \\
\hline$[027]$ & CBD - Sheridan \& Santa Fe & 35.46656 & 97.51310 & 634912 & 3925801 \\
\hline$[031]$ & CBD - Main \& Walker & 35.46772 & 97.52107 & 634187 & 3925919 \\
\hline$[032]$ & CBD - Main \& Hudson & 35.46767 & 97.51963 & 634318 & 3925915 \\
\hline$[033]$ & CBD - Main \& Harvey (Parking Lot) & 35.46742 & 97.51789 & 634476 & 3925890 \\
\hline$[034]$ & CBD - Main \& Robinson & 35.46760 & 97.51614 & 634635 & 3925912 \\
\hline$[036]$ & CBD - Main \& Broadway & 35.46756 & 97.51431 & 634801 & 3925910 \\
\hline$[037]$ & CBD - Main \& Santa Fe & 35.46749 & 97.51293 & 634926 & 3925904 \\
\hline$[041]$ & CBD - Walker btwn Colcord \& Couch & 35.46890 & 97.52138 & 634157 & 3926049 \\
\hline$[042]$ & CBD - Park \& Hudson & 35.46895 & 97.51966 & 634313 & 3926057 \\
\hline$[043]$ & CBD - Park \& Harvey & 35.46892 & 97.51810 & 634455 & 3926056 \\
\hline$[044]$ & CBD - Park \& Robinson (NE corner) & 35.46885 & 97.51656 & 634595 & 3926050 \\
\hline$[045]$ & CBD - Park between Robinson \& Broadway & 35.46869 & 97.51550 & 634691 & 3926034 \\
\hline$[046]$ & CBD - Park \& Broadway & 35.46882 & 97.51462 & 634771 & 3926049 \\
\hline$[047]$ & CBD - Park \& Santa Fe & 35.46870 & 97.51288 & 634929 & 3926038 \\
\hline
\end{tabular}


Table A.3. (contd)

\begin{tabular}{|c|c|c|c|c|c|}
\hline Instrument & Location Description & Latitude & Longitude & Easting & Northing \\
\hline$[051]$ & CBD - Kerr \& Walker & 35.46983 & 97.52111 & 634180 & 3926152 \\
\hline$[052]$ & CBD - Kerr \& Hudson & 35.46980 & 97.51938 & 634337 & 3926152 \\
\hline$[053]$ & CBD - Kerr \& Harvey & 35.46977 & 97.51783 & 634478 & 3926150 \\
\hline$[054]$ & CBD - Kerr \& Robinson & 35.46975 & 97.51630 & 634617 & 3926150 \\
\hline [055] & $\begin{array}{l}\text { CBD - S side Kerr between Robinson \& } \\
\text { Broadway (Kerr Parking Top) }\end{array}$ & 35.46972 & 97.51542 & 634697 & 3926148 \\
\hline$[056]$ & $\begin{array}{l}\text { CBD - Kerr \& Broadway (Broadway Kerr } \\
\text { Parking Garage) }\end{array}$ & 35.46970 & 97.51426 & 634802 & 3926147 \\
\hline$[057]$ & CBD - Kerr \& Santa Fe & 35.46963 & 97.51286 & 634929 & 3926142 \\
\hline$[058]$ & CBD - Kerr between Santa Fe \& Oklahoma & 35.46964 & 97.51158 & 635045 & 3926144 \\
\hline [059] & CBD - Kerr between Oklahoma \& Walnut & 35.46960 & 97.50983 & 635204 & 3926142 \\
\hline [061] & CBD - McGee \& Walker & 35.47106 & 97.52109 & 634180 & 3926289 \\
\hline [062] & CBD - McGee \& Hudson & 35.47105 & 97.51954 & 634321 & 3926290 \\
\hline [063] & CBD - McGee \& Harvey & 35.47099 & 97.51800 & 634460 & 3926285 \\
\hline [064] & CBD - McGee \& Robinson & 35.47095 & 97.51644 & 634602 & 3926283 \\
\hline [065] & CBD - McGee between Robinson \& Broadway & 35.47093 & 97.51542 & 634695 & 3926282 \\
\hline [066] & CBD - McGee \& just E of Broadway & 35.47072 & 97.51448 & 634780 & 3926260 \\
\hline [067] & CBD - McGee \& Santa Fe & 35.47079 & 97.51263 & 634948 & 3926270 \\
\hline [068] & CBD - McGee between Santa Fe \& Oklahoma & 35.47083 & 97.51144 & 635056 & 3926277 \\
\hline [069] & CBD - McGee between Oklahoma \& Walnut & 35.47080 & 97.51001 & 635186 & 3926275 \\
\hline [071] & CBD - N 4th \& Walker & 35.47192 & 97.52111 & 634177 & 3926384 \\
\hline [072] & CBD - N 4th \& Hudson & 35.47190 & 97.51929 & 634342 & 3926385 \\
\hline [073] & CBD - N 4th \& Harvey & 35.47186 & 97.51777 & 634480 & 3926382 \\
\hline [074] & CBD - N 4th \& Robinson & 35.47185 & 97.51620 & 634622 & 3926383 \\
\hline [076] & CBD - N 4th \& Broadway & 35.47176 & 97.51419 & 634805 & 3926376 \\
\hline [077] & CBD - N 4th btwn Broadway \& RR tracks & 35.47173 & 97.51262 & 634947 & 3926375 \\
\hline [078] & CBD - N 4th between RR tracks \& Oklahoma & 35.47172 & 97.51138 & 635060 & 3926375 \\
\hline [082] & CBD - N 5th \& Hudson & 35.47293 & 97.51926 & 634343 & 3926499 \\
\hline [083] & CBD - N 5th \& Harvey & 35.47310 & 97.51791 & 634465 & 3926520 \\
\hline [084] & CBD - N 5th \& Robinson & 35.47286 & 97.51617 & 634623 & 3926495 \\
\hline [086] & CBD - N 5th \& Broadway & 35.47279 & 97.51443 & 634781 & 3926490 \\
\hline [087] & CBD - N 5th btwn Broadway \& RR tracks & 35.47278 & 97.51278 & 634931 & 3926491 \\
\hline [094] & CBD - N 6th \& Robinson & 35.47410 & 97.51637 & 634603 & 3926632 \\
\hline [096] & CBD - N 6th \& Broadway & 35.47405 & 97.51445 & 634777 & 3926630 \\
\hline [401] & Tunnel - Broadway between Sheridan \& Main & 35.46724 & 97.51435 & 634798 & 3925874 \\
\hline [402] & $\begin{array}{l}\text { Tunnel - Broadway btwn Main \& Park (W of } \\
\text { Bank One Bldg) }\end{array}$ & 35.46824 & 97.51422 & 634808 & 3925985 \\
\hline [403] & Tunnel - Kerr \& Broadway & 35.46970 & 97.51452 & 634778 & 3926147 \\
\hline [404] & Tunnel - Kerr \& Harvey & 35.46996 & 97.51765 & 634494 & 3926172 \\
\hline [501] & 1 km Arc- California \& Shartel & 35.46532 & 97.52561 & 633779 & 3925646 \\
\hline [502] & 1 km Arc- Sheridan \& Shartel & 35.46663 & 97.52657 & 633690 & 3925790 \\
\hline [503] & 1 km Arc- Main btwn Fred Jones \& Shartel & 35.46777 & 97.52664 & 633682 & 3925916 \\
\hline [504] & 1 km Arc- Colcord \& Shartel & 35.46888 & 97.52557 & 633777 & 3926041 \\
\hline [505] & 1 km Arc- Kerr \& Shartel & 35.47011 & 97.52640 & 633700 & 3926176 \\
\hline [506] & 1 km Arc- Shartel btwn N 3rd \& N 4th & 35.47160 & 97.52559 & 633771 & 3926343 \\
\hline [507] & 1 km Arc- Lee btwn N 4th \& N 5th & 35.47258 & 97.52430 & 633886 & 3926453 \\
\hline
\end{tabular}


Table A.3. (contd)

\begin{tabular}{|c|c|c|c|c|c|}
\hline Instrument & Location Description & Latitude & Longitude & Easting & Northing \\
\hline [508] & 1 km Arc- Lee btwn N 5th \& N 6th & 35.47426 & 97.52418 & 633894 & 3926640 \\
\hline [509] & 1 km Arc- Dewey btwn N 6th \& N 7th & 35.47485 & 97.52275 & 634023 & 3926707 \\
\hline [510] & 1 km Arc- N 7th \& Walker & 35.47512 & 97.52115 & 634168 & 3926739 \\
\hline [511] & $\begin{array}{l}1 \text { km Arc- btwn N 7th \& N 8th and Walker \& } \\
\text { Hudson }\end{array}$ & 35.47571 & 97.52049 & 634227 & 3926805 \\
\hline [512] & 1 km Arc- N 8th \& Hudson & 35.47630 & 97.51912 & 634350 & 3926873 \\
\hline [513] & 1 km Arc- N 8th \& Harvey & 35.47631 & 97.51780 & 634470 & 3926876 \\
\hline [514] & $\begin{array}{l}1 \text { km Arc- btwn N 8th \& N 9th and Harvey \& } \\
\text { Robinson }\end{array}$ & 35.47667 & 97.51677 & 634563 & 3926917 \\
\hline [515] & $\begin{array}{l}1 \text { km Arc- btwn N 8th \& N 9th and Robinson \& } \\
\text { Broadway }\end{array}$ & 35.47661 & 97.51580 & 634651 & 3926912 \\
\hline$[516]$ & 1 km Arc- Broadway btwn N 8th \& N 9th & 35.47653 & 97.51432 & 634785 & 3926905 \\
\hline [517] & 1 km Arc- N 9th btwn Broadway \& RR tracks & 35.47702 & 97.51303 & 634901 & 3926961 \\
\hline [518] & 1 km Arc- N 8th btwn RR tracks \& Oklahoma & 35.47608 & 97.51154 & 635038 & 3926859 \\
\hline [519] & 1 km Arc- Oklahoma btwn N 7th \& N 8th & 35.47547 & 97.51050 & 635133 & 3926792 \\
\hline [520] & 1 km Arc- N 7th btwn Oklahoma \& Walnut & 35.47490 & 97.50977 & 635201 & 3926730 \\
\hline [521] & 1 km Arc- On overpass (Harrison) btwn 6th \& 7th & 35.47423 & 97.50820 & 635344 & 3926658 \\
\hline [522] & 1 km Arc- Stiles btwn $\mathrm{N}$ 6th \& N 7th & 35.47461 & 97.50578 & 635563 & 3926704 \\
\hline [523] & 1 km Arc- N 5th btwn Stiles \& Geary & 35.47304 & 97.50498 & 635638 & 3926530 \\
\hline [531] & 2km Arc - California \& McKinley & 35.46489 & 97.53744 & 632707 & 3925582 \\
\hline [532] & 2km Arc - Main \& McKinley & 35.46773 & 97.53726 & 632718 & 3925898 \\
\hline [533] & 2km Arc - McKinley btwn N 2nd \& N 3rd & 35.47052 & 97.53696 & 632741 & 3926208 \\
\hline [534] & 2km Arc - N 5th \& McKinley & 35.47309 & 97.53725 & 632710 & 3926492 \\
\hline [535] & 2km Arc - Brauer btwn Linwood \& N 7th & 35.47539 & 97.53562 & 632854 & 3926749 \\
\hline [536] & 2km Arc - N 9th \& Douglas & 35.47780 & 97.53457 & 632946 & 3927018 \\
\hline [537] & 2km Arc - N 19th \& Klein & 35.47895 & 97.53186 & 633190 & 3927149 \\
\hline [538] & 2km Arc - N 11th \& Western & 35.48078 & 97.53009 & 633347 & 3927355 \\
\hline [539] & 2km Arc - N 13th \& Francis & 35.48249 & 97.52724 & 633603 & 3927548 \\
\hline [540] & 2km Arc - N 14th \& Shartel & 35.48371 & 97.52559 & 633751 & 3927686 \\
\hline [541] & 2km Arc - N 15th btwn Lee \& Dewey & 35.48480 & 97.52320 & 633966 & 3927810 \\
\hline [542] & 2km Arc - N 15th btwn Walker \& Hudson & 35.48477 & 97.52114 & 634153 & 3927810 \\
\hline [543] & 2km Arc - N 16th btwn Hudson \& Harvey & 35.48617 & 97.51798 & 634437 & 3927969 \\
\hline [544] & 2km Arc - N 16th \& Robinson & 35.48603 & 97.51540 & 634671 & 3927957 \\
\hline [545] & 2km Arc - N 16th btwn Broadway \& RR tracks & 35.48598 & 97.51232 & 634951 & 3927956 \\
\hline [546] & 2 km Arc- N 16th btwn Oklahoma \& Walnut & 35.48538 & 97.51023 & 635141 & 3927892 \\
\hline [547] & 2 km Arc- N 15th btwn Walnut \& Stiles & 35.48455 & 97.50748 & 635392 & 3927804 \\
\hline [548] & 2 km Arc- N 14th btwn Stiles \& Lincoln & 35.48363 & 97.50513 & 635607 & 3927705 \\
\hline [549] & 2 km Arc- N 13th \& Lincoln & 35.48244 & 97.50345 & 635761 & 3927575 \\
\hline [550] & 2 km Arc- SL Young \& Lindsay & 35.48015 & 97.50180 & 635915 & 3927324 \\
\hline [551] & 2 km Arc- Philips btwn N 10th \& SL Young & 35.47892 & 97.49903 & 636168 & 3927191 \\
\hline [561] & 4km Arc - S 2nd \& Linn & 35.46247 & 97.55904 & 630750 & 3925285 \\
\hline [562] & 4km Arc - Main \& Linn & 35.46802 & 97.55898 & 630747 & 3925901 \\
\hline [563] & 4km Arc - General Pershing \& Villa & 35.47307 & 97.55682 & 630935 & 3926464 \\
\hline [564] & 4km Arc - N 10th \& Villa & 35.47866 & 97.55646 & 630958 & 3927084 \\
\hline [565] & 4km Arc - N 13th \& Billan & 35.48290 & 97.55440 & 631138 & 3927557 \\
\hline$[566]$ & 4km Arc - N 17th \& Youngs & 35.48690 & 97.55211 & 631340 & 3928004 \\
\hline
\end{tabular}


Table A.3. (contd)

\begin{tabular}{|c|c|c|c|c|c|}
\hline Instrument & Location Description & Latitude & Longitude & Easting & Northing \\
\hline [567] & 4km Arc - N 21st \& Barnes & 35.49098 & 97.54939 & 631580 & 3928460 \\
\hline$[568]$ & 4km Arc - N 23rd \& Virginia & 35.49424 & 97.54558 & 631920 & 3928827 \\
\hline [569] & 4km Arc - N 27th \& Florida & 35.49760 & 97.54061 & 632365 & 3929206 \\
\hline$[570]$ & 4km Arc - N 29th \& McKinley & 35.49944 & 97.53672 & 632715 & 3929416 \\
\hline$[571]$ & 4km Arc - N 31st \& Lake & 35.50166 & 97.53094 & 633236 & 3929670 \\
\hline [572] & 4km Arc - N 32nd \& Shartel & 35.50255 & 97.52535 & 633741 & 3929776 \\
\hline$[573]$ & 4km Arc - Hill \& Walker & 35.50342 & 97.52101 & 634133 & 3929878 \\
\hline [574] & 4km Arc - N 33rd \& Robinson & 35.50355 & 97.51564 & 634620 & 3929900 \\
\hline [575] & 4km Arc - Hill btwn Santa Fe \& Walnut & 35.50328 & 97.51125 & 635019 & 3929876 \\
\hline [576] & 4 km Arc- Hill btwn Walnut \& Lincoln & 35.50308 & 97.50606 & 635490 & 3929861 \\
\hline [577] & 4 km Arc- N 31st \& Lindsay & 35.50150 & 97.50098 & 635953 & 3929693 \\
\hline [578] & 4 km Arc- N 29th \& Kelley & 35.49955 & 97.49450 & 636544 & 3929485 \\
\hline [579] & 4 km Arc- N 25th \& Lottie & 35.49591 & 97.48953 & 637001 & 3929089 \\
\hline [580] & 4 km Arc- Madison \& Prospect & 35.49398 & 97.48545 & 637375 & 3928880 \\
\hline$[581]$ & 4 km Arc- N 20th \& Rhode Island & 35.48938 & 97.48101 & 637785 & 3928376 \\
\hline [940] & $\begin{array}{l}\text { Rooftop - Park between Harvey \& Robinson } \\
\text { (Oklahoma Tower Roof - 117m agl) }\end{array}$ & 35.46855 & 97.51708 & 634548 & 3926016 \\
\hline [945] & $\begin{array}{l}\text { Rooftop - Park btwn Robinson \& Broadway } \\
\text { (Chamber of Commerce roof - 17m agl) }\end{array}$ & 35.46889 & 97.51546 & 634694 & 3926056 \\
\hline [946] & $\begin{array}{l}\text { Rooftop - NW corner of Park \& Broadway (Sonic } \\
\text { Building Roof }-47 \mathrm{~m} \text { agl) }\end{array}$ & 35.46891 & 97.51470 & 634763 & 3926059 \\
\hline [950] & $\begin{array}{l}\text { Rooftop - NE corner of Kerr \& Robinson (39m } \\
\text { agl) }\end{array}$ & 35.47001 & 97.51609 & 634635 & 3926179 \\
\hline [954] & $\begin{array}{l}\text { Rooftop - W side Robinson between Kerr \& } \\
\text { McGee (Bank of Oklahoma - 78m agl) }\end{array}$ & 35.47032 & 97.51672 & 634578 & 3926213 \\
\hline [955] & $\begin{array}{l}\text { Rooftop - Kerr btwn Robinson \& Broadway (Kerr } \\
\text { McGee Center - 115m agl) }\end{array}$ & 35.47023 & 97.51523 & 634713 & 3926205 \\
\hline [956] & $\begin{array}{l}\text { Rooftop - Kerr btwn Robinson \& Broadway (Kerr } \\
\text { McGee Center - 26m agl) }\end{array}$ & 35.46991 & 97.51461 & 634770 & 3926170 \\
\hline [963] & $\begin{array}{l}\text { Rooftop - NW corner of McGee \& Harvey (ONG } \\
\text { Building roof - 20m agl) }\end{array}$ & 35.47113 & 97.51807 & 634454 & 3926301 \\
\hline [964] & $\begin{array}{l}\text { Rooftop - McGee btwn Harvey \& Robinson (Old } \\
\text { Post Office Roof - 37m agl) }\end{array}$ & 35.47115 & 97.51705 & 634546 & 3926304 \\
\hline [965] & $\begin{array}{l}\text { Rooftop - Broadway \& McGee (SW Bell Bldg } \\
\text { Roof - 72m agl) }\end{array}$ & 35.47097 & 97.51542 & 634695 & 3926287 \\
\hline
\end{tabular}




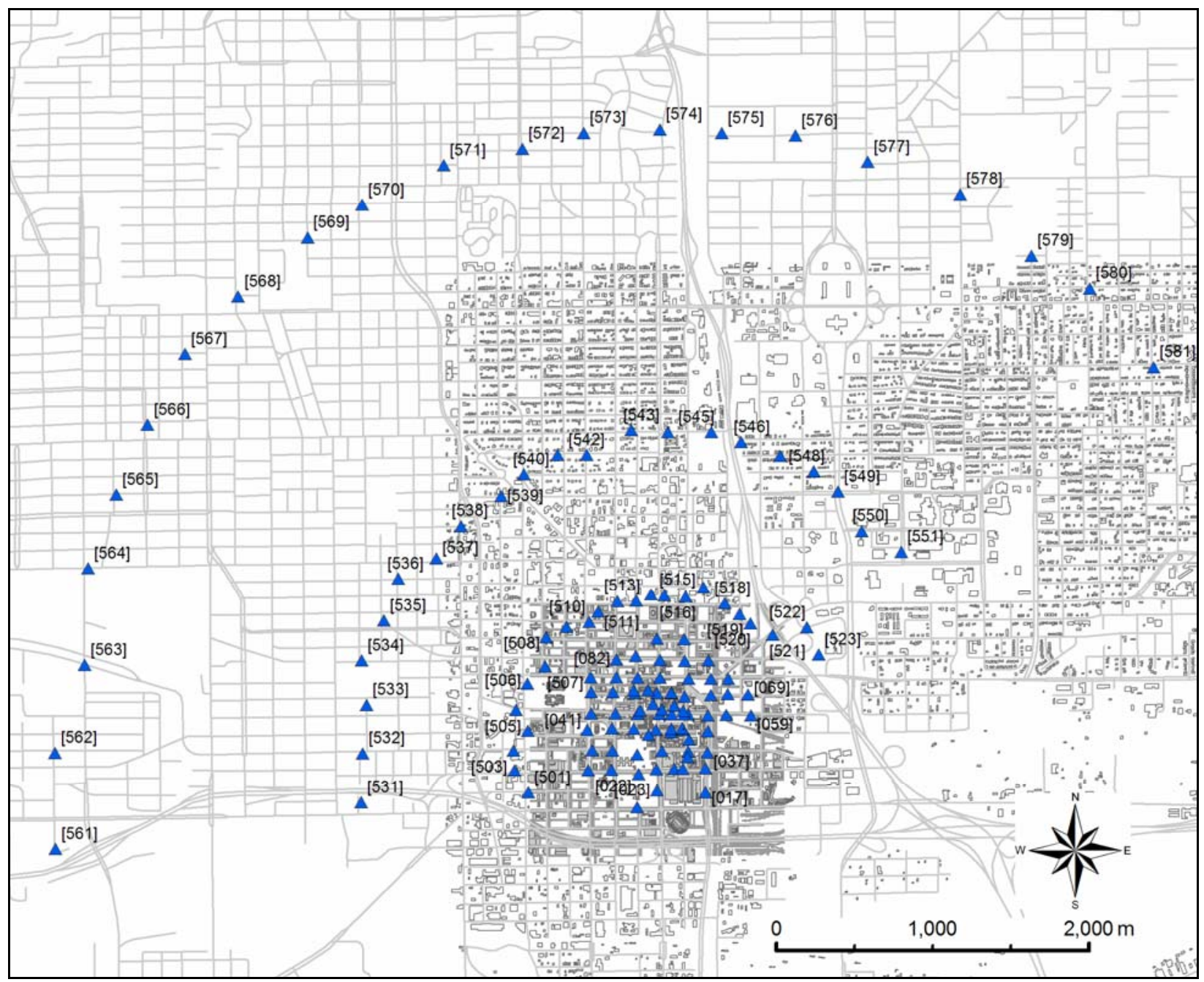

Figure A.5. Overview of ARLFRD PIGS and S-PIGS Tracer Sampler Instruments 


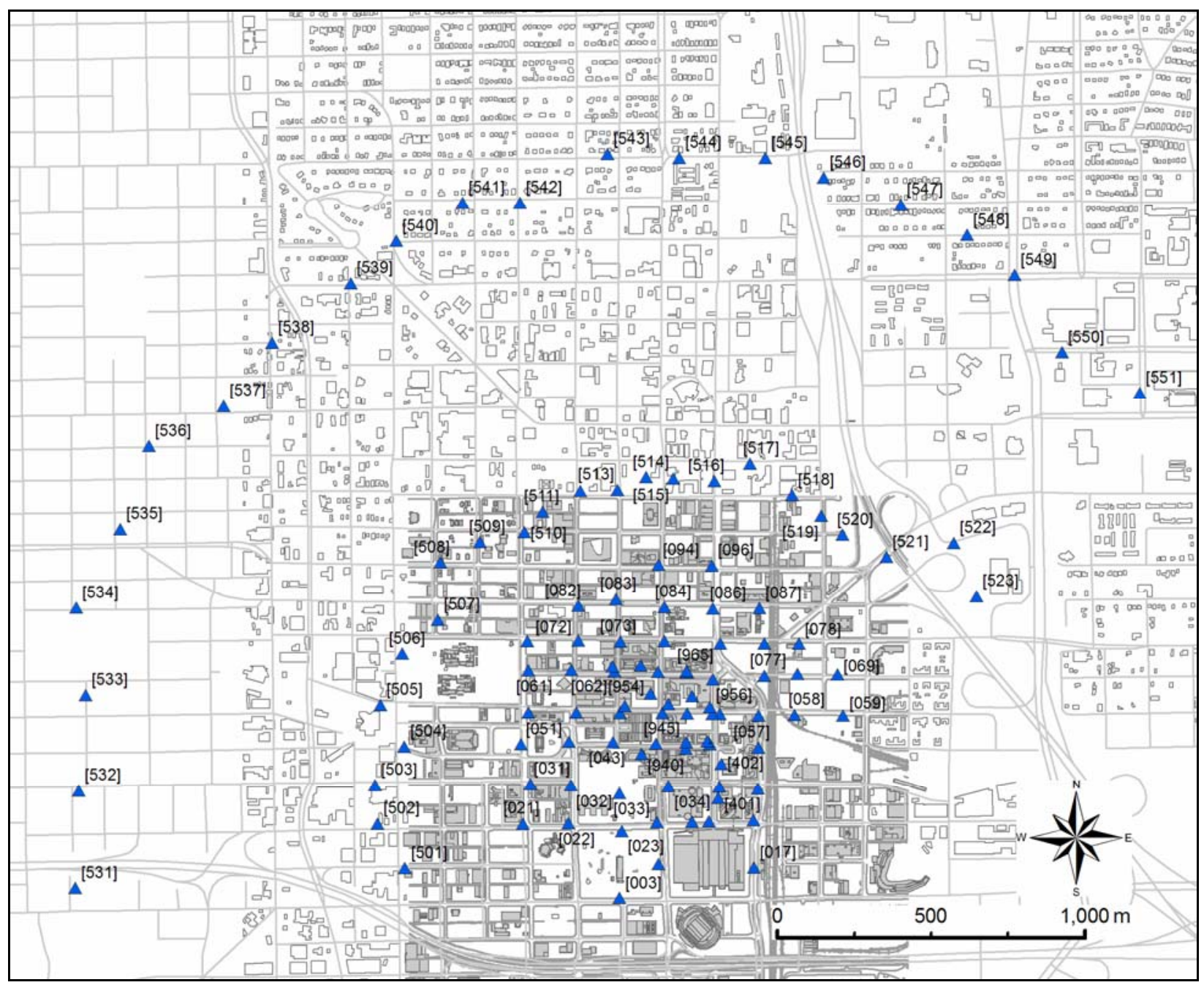

Figure A.6. ARLFRD PIGS and S-PIGS Tracer Sampler Instruments, Zoomed into the 2-km Arc 


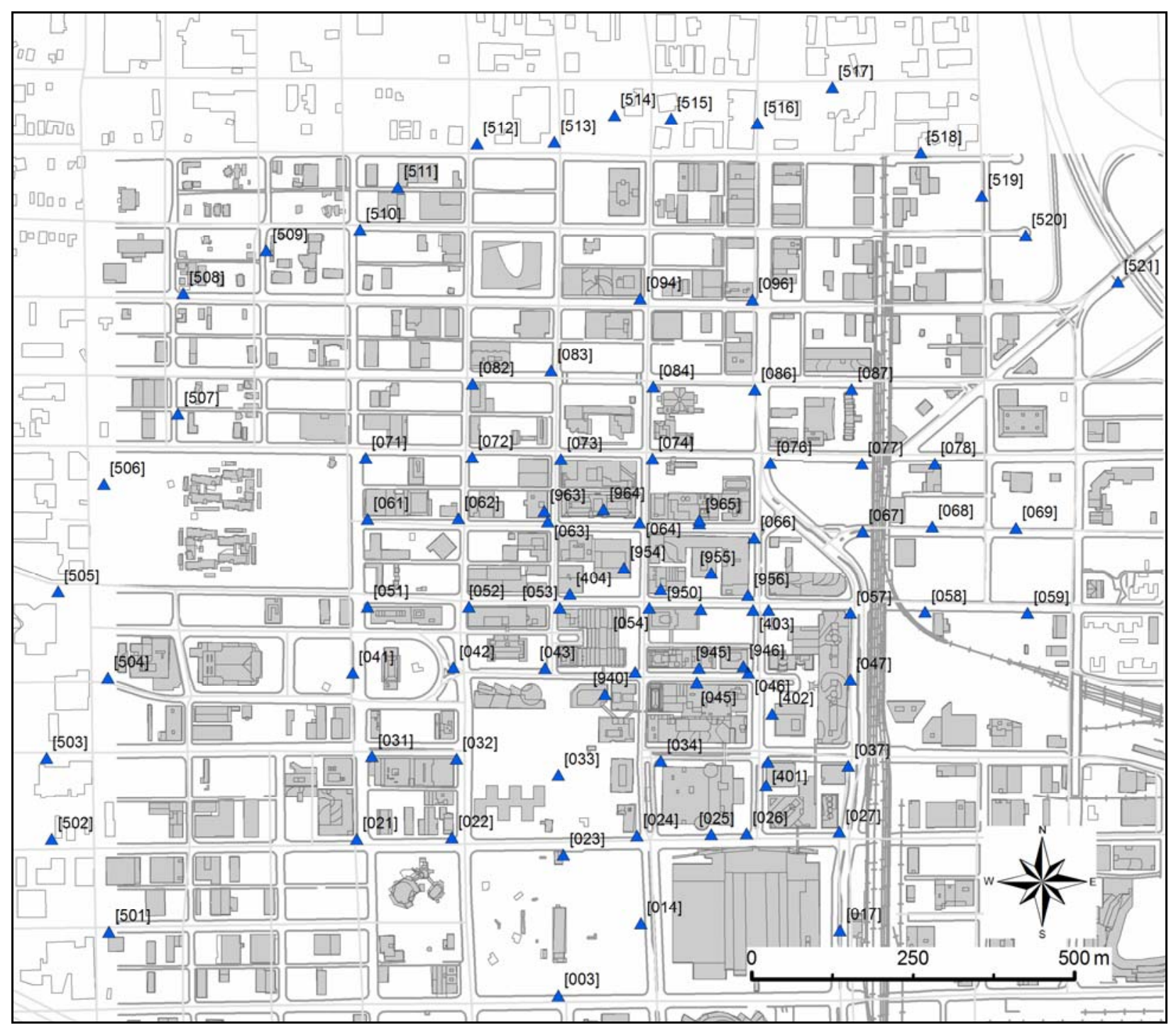

Figure A.7. ARLFRD PIGS and S-PIGS Tracer Sampler Instruments, Zoomed into the 1-km Arc 
Table A.4. ARLFRD Trace Gas Analyzer Instrument Locations. Instruments marked a, b, and c represents changes in position during the IOP. See Clawson et al (2005) for additional details.

\begin{tabular}{|c|c|c|c|c|c|}
\hline Instrument & Location Description & Latitude & Longitude & Easting & Northing \\
\hline IOP1 - [0] & $\begin{array}{l}\text { NW Corner of Kerr \& Broadway, parking meter } \\
2085\end{array}$ & 35.46986 & 97.51470 & 634762 & 3926164 \\
\hline IOP1 - [1] & $\begin{array}{l}\text { S. side McGee btwn Robinson \& Broadway, } \\
\text { parking meter } 0459\end{array}$ & 35.47080 & 97.51559 & 634679 & 3926268 \\
\hline IOP1 - [2] & $\begin{array}{l}\text { S. side McGee btwn Harvey \& Robinson (in } \\
\text { front of Old Post Office) }\end{array}$ & 35.47085 & 97.51720 & 634533 & 3926271 \\
\hline IOP1 - [3] & $\begin{array}{l}\text { S. side Park btwn Robinson \& Broadway (in } \\
\text { front of Hallmark store) }\end{array}$ & 35.46871 & 97.51560 & 634682 & 3926036 \\
\hline IOP1 - [4] & $\begin{array}{l}\text { Park Ave E of Broadway meter } 0012 \text { (in front } \\
\text { of Skirvin Hotel) }\end{array}$ & 35.46856 & 97.51409 & 634819 & 3926021 \\
\hline IOP1 - [5] & Mobile on 4th Street & & & & \\
\hline IOP1 - [6] & $\begin{array}{l}\text { S. side Main btwn Robinson \& Broadway, } \\
\text { parking meter } 2092\end{array}$ & 35.46760 & 97.51550 & 634693 & 3925913 \\
\hline IOP1 - [7] & Top of Main Street Parking Garage [27m agl] & 35.46790 & 97.51550 & 634692 & 3925946 \\
\hline IOP1 - [8] & $\begin{array}{l}\text { SW corner of McGee \& Broadway, parking } \\
\text { meter } 0464\end{array}$ & 35.47078 & 97.51460 & 634769 & 3926267 \\
\hline IOP1 - [9] & NW corner of Park \& Robinson meter 2113 & 35.46882 & 97.51661 & 634590 & 3926046 \\
\hline IOP2 - [0] & NW Corner of Kerr \& Broadway meter 2085 & 35.46986 & 97.51470 & 634762 & 3926164 \\
\hline IOP2 - [1a] & $\begin{array}{l}\text { S. side McGee btwn Robinson \& Broadway, } \\
\text { parking meter } 0459\end{array}$ & 35.47080 & 97.51559 & 634679 & 3926268 \\
\hline IOP2 - [1b] & On 3rd St. btwn Walnut \& Oklahoma & 35.47069 & 97.50990 & 635196 & 3926263 \\
\hline IOP2 - [2a] & $\begin{array}{l}\text { S. side McGee btwn Harvey \& Robinson (in } \\
\text { front of Old Post Office) }\end{array}$ & 35.47085 & 97.51720 & 634533 & 3926271 \\
\hline IOP2 - [2b] & $\begin{array}{l}\text { 3rd \& Gaylord parking meter } 0034 \text { (just W of } \\
\text { RR overpass) }\end{array}$ & 35.47087 & 97.51260 & 634951 & 3926279 \\
\hline IOP2 - [3] & $\begin{array}{l}\text { S. side Park btwn Robinson \& Broadway (in } \\
\text { front of Hallmark store) }\end{array}$ & 35.46871 & 97.51560 & 634682 & 3926036 \\
\hline IOP2 - [4a] & SW corner 4th Street \& Harvey, meter 1063 & 35.47193 & 97.51810 & 634450 & 3926389 \\
\hline IOP2 - [4b] & 4th \& Gaylord (just E of RR overpass) & 35.47168 & 97.51190 & 635013 & 3926370 \\
\hline IOP2 - [5] & Mobile on 4th Street & & & & \\
\hline IOP2 - [6a] & SW corner Kerr \& Harvey, meter 1119 & 35.46980 & 97.51810 & 634453 & 3926153 \\
\hline IOP2 - [6b] & SW corner 2nd \& Oklahoma & 35.46963 & 97.51080 & 635116 & 3926144 \\
\hline IOP2 - [7a] & SE corner Kerr \& Hudson, meter 1112 & 35.46982 & 97.51930 & 634344 & 3926154 \\
\hline IOP2 - [7b] & 2nd \& Gaylord (just E of RR overpass) & 35.46966 & 97.51170 & 635034 & 3926146 \\
\hline IOP2 - [8] & $\begin{array}{l}\text { SW corner of McGee \& Broadway, parking } \\
\text { meter } 0464\end{array}$ & 35.47078 & 97.51460 & 634769 & 3926267 \\
\hline IOP2 - [9a] & NW corner of Park and Robinson meter 2113 & 35.46882 & 97.51661 & 634590 & 3926046 \\
\hline IOP2 - [9b] & NW corner of 4 th $\&$ Walnut & 35.47194 & 97.50920 & 635257 & 3926403 \\
\hline IOP $3 \& 4$ & Stationary vans, same as IOP 1 & & & & \\
\hline IOP3 - [5] & Mobile on $4^{\text {th }}, 8^{\text {th }}, 10^{\text {th }}$, and $16^{\text {th }}$ Streets & & & & \\
\hline IOP4 - [5] & Mobile on $4^{\text {th }}$ and $8^{\text {th }}$ Streets & & & & \\
\hline IOP5 - [0a] & NW Corner of Kerr \& Broadway meter 2085 & 35.46986 & 97.51470 & 634762 & 3926164 \\
\hline IOP5 - [0b] & SE Corner of Harvey \& Kerr & 35.46980 & 97.51810 & 634453 & 3926153 \\
\hline IOP5 - [1a] & $\begin{array}{l}\text { N side Kerr btwn Robinson \& Broadway (in } \\
\text { front of Kerr Tower) }\end{array}$ & 35.46987 & 97.51540 & 634698 & 3926165 \\
\hline
\end{tabular}


Table A.4. (contd)

\begin{tabular}{|c|c|c|c|c|c|}
\hline Instrument & Location Description & Latitude & Longitude & Easting & Northing \\
\hline IOP5 - [1b] & $\begin{array}{l}\text { McGee btwn Broadway \& Robinson, parking } \\
\text { meter } 0459\end{array}$ & 35.47080 & 97.51559 & 634679 & 3926268 \\
\hline IOP5 - [2a] & $\begin{array}{l}\text { S side McGee btwn Harvey \& Robinson (in } \\
\text { front of Old Post Office) }\end{array}$ & 35.47085 & 97.51720 & 634533 & 3926271 \\
\hline IOP5 - [2b] & 4th St just E of Hudson, parking meter 1055 & 35.47194 & 97.51920 & 634350 & 3926389 \\
\hline IOP5 - [3a] & $\begin{array}{l}\text { S side Park btwn Robinson \& Broadway (in } \\
\text { front of Hallmark store) }\end{array}$ & 35.46871 & 97.51560 & 634682 & 3926036 \\
\hline IOP5 - [3b] & SW corner Main \& Hudson & 35.46776 & 97.51981 & 634302 & 3925925 \\
\hline IOP5 - [4] & $\begin{array}{l}\text { Park E of Broadway meter } 0012 \text { (in front of } \\
\text { Skirvin Hotel) }\end{array}$ & 35.46856 & 97.51409 & 634819 & 3926021 \\
\hline IOP5 - [5] & Mobile on 4th \& 8th Streets \& CBD & & & & \\
\hline IOP5 - [6] & $\begin{array}{l}\text { S side Main btwn Robinson \& Broadway, } \\
\text { parking meter } 2092\end{array}$ & 35.46760 & 97.51550 & 634693 & 3925913 \\
\hline IOP5 - [7] & $\begin{array}{l}\text { Top of Main Street Parking Garage [27m } \\
\text { agl] }\end{array}$ & 35.46790 & 97.51550 & 634692 & 3925946 \\
\hline IOP5 - [8a] & NW corner of McGee \& Broadway & 35.47098 & 97.51447 & 634781 & 3926289 \\
\hline IOP5 - [8b] & SE corner of Hudson \& McGee, meter 1090 & 35.47091 & 97.51930 & 634343 & 3926275 \\
\hline IOP5 - [9] & NW corner of Park \& Robinson, meter 2113 & 35.46882 & 97.51661 & 634590 & 3926046 \\
\hline IOP 6 & Same as IOP 1 & & & & \\
\hline IOP7 - [0a] & NW Corner of Kerr \& Broadway meter 2085 & 35.46986 & 97.51470 & 634762 & 3926164 \\
\hline IOP7 - [0c] & $\begin{array}{l}\text { SW corner of 2nd \& Walnut (in front of } \\
\text { Finley Bldg) }\end{array}$ & 35.46963 & 97.50920 & 635261 & 3926147 \\
\hline IOP7 - [1a] & $\begin{array}{l}\text { S side McGee btwn Broadway \& Robinson, } \\
\text { parking meter } 0459\end{array}$ & 35.47080 & 97.51559 & 634679 & 3926268 \\
\hline IOP7 - [1b] & 3rd St btwn Walnut \& Oklahoma & 35.47069 & 97.50990 & 635196 & 3926263 \\
\hline IOP7 - [2a] & $\begin{array}{l}\text { S side McGee btwn Harvey \& Robinson (in } \\
\text { front of Old Post Office) }\end{array}$ & 35.47085 & 97.51720 & 634533 & 3926271 \\
\hline IOP7 - [2b] & $\begin{array}{l}\text { Corner of 3rd \& Gaylord, parking meter } \\
0034 \text { (just W of RR overpass) }\end{array}$ & 35.47087 & 97.51260 & 634951 & 3926279 \\
\hline IOP7 - [3a] & $\begin{array}{l}\text { S side Park btwn Robinson \& Broadway (in } \\
\text { front of Hallmark store) }\end{array}$ & 35.46871 & 97.51560 & 634682 & 3926036 \\
\hline IOP7 - [3c] & $\begin{array}{l}\text { SW corner of 4th \& Walnut (in front of } \\
\text { Bricktown Auto Bath \& Shine) }\end{array}$ & 35.47171 & 97.50910 & 635267 & 3926377 \\
\hline IOP7 - [4] & $\begin{array}{l}\text { Park E of Broadway meter } 0012 \text { (in front of } \\
\text { Skirvin Hotel) }\end{array}$ & 35.46856 & 97.51409 & 634819 & 3926021 \\
\hline IOP7 - [5] & Mobile on 4th Street & & & & \\
\hline IOP7 - [6a] & $\begin{array}{l}\text { S side Main btwn Robinson \& Broadway, } \\
\text { parking meter } 2092\end{array}$ & 35.46760 & 97.51550 & 634693 & 3925913 \\
\hline IOP7 - [6c] & SW corner of Gaylord \& Main, meter 2050 & 35.46754 & 97.51310 & 634911 & 3925909 \\
\hline IOP7 - [7a] & Top of Main Street Parking Garage & 35.46790 & 97.51550 & 634692 & 3925946 \\
\hline IOP7 - [7c] & $100 \mathrm{ft} \mathrm{S}$ of Stiles on $4 \mathrm{th} \mathrm{St}$ & 35.47145 & 97.50590 & 635558 & 3926353 \\
\hline IOP7 - [8a] & $\begin{array}{l}\text { SW corner of McGee \& Broadway, parking } \\
\text { meter } 0464\end{array}$ & 35.47078 & 97.51460 & 634769 & 3926267 \\
\hline IOP7 - [8c] & SW corner of 3rd \& Central & 35.47066 & 97.50760 & 635405 & 3926263 \\
\hline
\end{tabular}


Table A.4. (contd)

\begin{tabular}{|c|c|c|c|c|c|}
\hline Instrument & Location Description & Latitude & Longitude & Easting & Northing \\
\hline IOP7 - [9a] & NW corner of Park \& Robinson, meter 2113 & 35.46882 & 97.51661 & 634590 & 3926046 \\
\hline IOP7 - [9b] & 2nd \& Gaylord (just E of RR overpass) & 35.46966 & 97.51170 & 635034 & 3926146 \\
\hline IOP8 - [0a] & NW Corner of Kerr \& Broadway meter 2085 & 35.46986 & 97.51470 & 634762 & 3926164 \\
\hline IOP8 - [0b] & SW corner of 4th \& Harvey, meter 1063 & 35.47190 & 97.51810 & 634450 & 3926386 \\
\hline IOP8 - [1] & $\begin{array}{l}\text { S side McGee btwn Broadway \& Robinson, } \\
\text { parking meter } 0459\end{array}$ & 35.47080 & 97.51559 & 634679 & 3926268 \\
\hline IOP8 - [2] & $\begin{array}{l}\text { S side McGee btwn Harvey \& Robinson (in } \\
\text { front of Old Post Office) }\end{array}$ & 35.47085 & 97.51720 & 634533 & 3926271 \\
\hline IOP8 - [3] & $\begin{array}{l}\text { S side Park btwn Robinson \& Broadway (in } \\
\text { front of Hallmark store) }\end{array}$ & 35.46871 & 97.51560 & 634682 & 3926036 \\
\hline IOP8 - [4a] & SW corner of 4th \& Harvey, meter 1063 & 35.47190 & 97.51810 & 634450 & 3926386 \\
\hline IOP8 - [4b] & NW Corner of Kerr \& Broadway meter 2085 & 35.46986 & 97.51470 & 634762 & 3926164 \\
\hline IOP8 - [5] & Mobile on 8th Street & & & & \\
\hline IOP8 - [6] & SW corner of Kerr \& Harvey, meter 1119 & 35.46980 & 97.51810 & 634453 & 3926153 \\
\hline IOP8 - [7] & SE corner of Kerr \& Hudson, meter 1112 & 35.46980 & 97.51930 & 634344 & 3926152 \\
\hline IOP8 - [8] & $\begin{array}{l}\text { SW corner of McGee \& Broadway, parking } \\
\text { meter } 0464\end{array}$ & 35.47078 & 97.51460 & 634769 & 3926267 \\
\hline IOP8 - [9] & NW corner of Park \& Robinson, meter 2113 & 35.46882 & 97.51661 & 634590 & 3926046 \\
\hline IOP9 - [0a] & $\begin{array}{l}\text { N side Park btwn Harvey \& Robinson, } \\
\text { parking meter } 2121 \text { (under elev walkway) }\end{array}$ & 35.46884 & 97.51720 & 634537 & 3926048 \\
\hline IOP9 - [0b] & S side 4th St just $\mathrm{W}$ of tracks & 35.47168 & 97.51260 & 634949 & 3926369 \\
\hline IOP9 - [1] & $\begin{array}{l}\text { S side McGee btwn Broadway \& Robinson, } \\
\text { parking meter } 0459\end{array}$ & 35.47080 & 97.51559 & 634679 & 3926268 \\
\hline IOP9 - [2] & $\begin{array}{l}\text { S side McGee btwn Harvey \& Robinson (in } \\
\text { front of Old Post Office) }\end{array}$ & 35.47085 & 97.51720 & 634533 & 3926271 \\
\hline IOP9 - [3] & S side Kerr btwn Harvey \& Robinson & 35.46978 & 97.51730 & 634526 & 3926152 \\
\hline IOP9 - [4] & S side Kerr btwn Broadway \& Gaylord & 35.46965 & 97.51370 & 634853 & 3926143 \\
\hline IOP9 - [5] & Mobile on 8th Street & & & & \\
\hline IOP9 - [6] & $\begin{array}{l}\text { NW corner of Kerr \& Robinson, parking } \\
\text { meter } 2131 \text { (in front of Bank of OK) }\end{array}$ & 35.46989 & 97.51660 & 634589 & 3926165 \\
\hline IOP9 - [7] & NW corner of Kerr \& Broadway, meter 2085 & 35.46986 & 97.51470 & 634762 & 3926164 \\
\hline IOP9 - [8] & $\begin{array}{l}\text { SW corner of McGee \& Broadway, parking } \\
\text { meter } 0464\end{array}$ & 35.47078 & 97.51460 & 634769 & 3926267 \\
\hline IOP9 - [9] & N side Kerr btwn Robinson \& Broadway & 35.46987 & 97.51540 & 634698 & 3926165 \\
\hline IOP10 - [0a] & $\begin{array}{l}\text { N side Park btwn Harvey \& Robinson, } \\
\text { parking meter } 2121 \text { (under elev walkway) }\end{array}$ & 35.46884 & 97.51720 & 634537 & 3926048 \\
\hline IOP10 - [0b] & SW corner of 5th \& Broadway & 35.47279 & 97.51450 & 634775 & 3926490 \\
\hline IOP10 - [1] & $\begin{array}{l}\text { S side McGee btwn Broadway \& Robinson, } \\
\text { parking meter } 0459\end{array}$ & 35.47080 & 97.51559 & 634679 & 3926268 \\
\hline IOP10 - [2a] & $\begin{array}{l}\text { S side McGee btwn Harvey \& Robinson (in } \\
\text { front of Old Post Office) }\end{array}$ & 35.47085 & 97.51720 & 634533 & 3926271 \\
\hline IOP10 - [2c] & Corner of 4th \& Oklahoma & 35.47165 & 97.51070 & 635122 & 3926369 \\
\hline IOP10 - [3a] & S side Kerr btwn Harvey \& Robinson & 35.46978 & 97.51730 & 634526 & 3926152 \\
\hline IOP10 - [3b] & S side 5th St btwn Broadway \& RR tracks & 35.47281 & 97.51280 & 634929 & 3926494 \\
\hline
\end{tabular}


Table A.4. (contd)

\begin{tabular}{|l|l|c|c|c|c||}
\hline \hline Instrument & Location Description & Latitude & Longitude & Easting & Northing \\
\hline \hline IOP10 - [4] & S side Kerr btwn Broadway \& Gaylord & 35.46965 & 97.51370 & 634853 & 3926143 \\
\hline IOP10 - [5] & Mobile on 8th Street & & & & \\
\hline IOP10 - [6a] & $\begin{array}{l}\text { NW corner of Kerr \& Robinson, parking } \\
\text { meter 2131 (in front of Bank of OK) }\end{array}$ & 35.46989 & 97.51660 & 634589 & 3926165 \\
\hline IOP10 - [6c] & N side Kerr btwn Robinson \& Broadway & 35.46987 & 97.51540 & 634698 & 3926165 \\
IOP10 - [7] & NW corner of Kerr \& Broadway, meter 2085 & 35.46986 & 97.51470 & 634762 & 3926164 \\
\hline IOP10 - [8] & $\begin{array}{l}\text { SW corner of McGee \& Broadway, parking } \\
\text { meter 0464 }\end{array}$ & 35.47078 & 97.51460 & 634769 & 3926267 \\
\hline IOP10 - [9a] & N side of Kerr btwn Robinson \& Broadway & 35.46987 & 97.51540 & 634698 & 3926165 \\
\hline IOP10 - [9c] & Out of commission & & & & \\
\hline
\end{tabular}
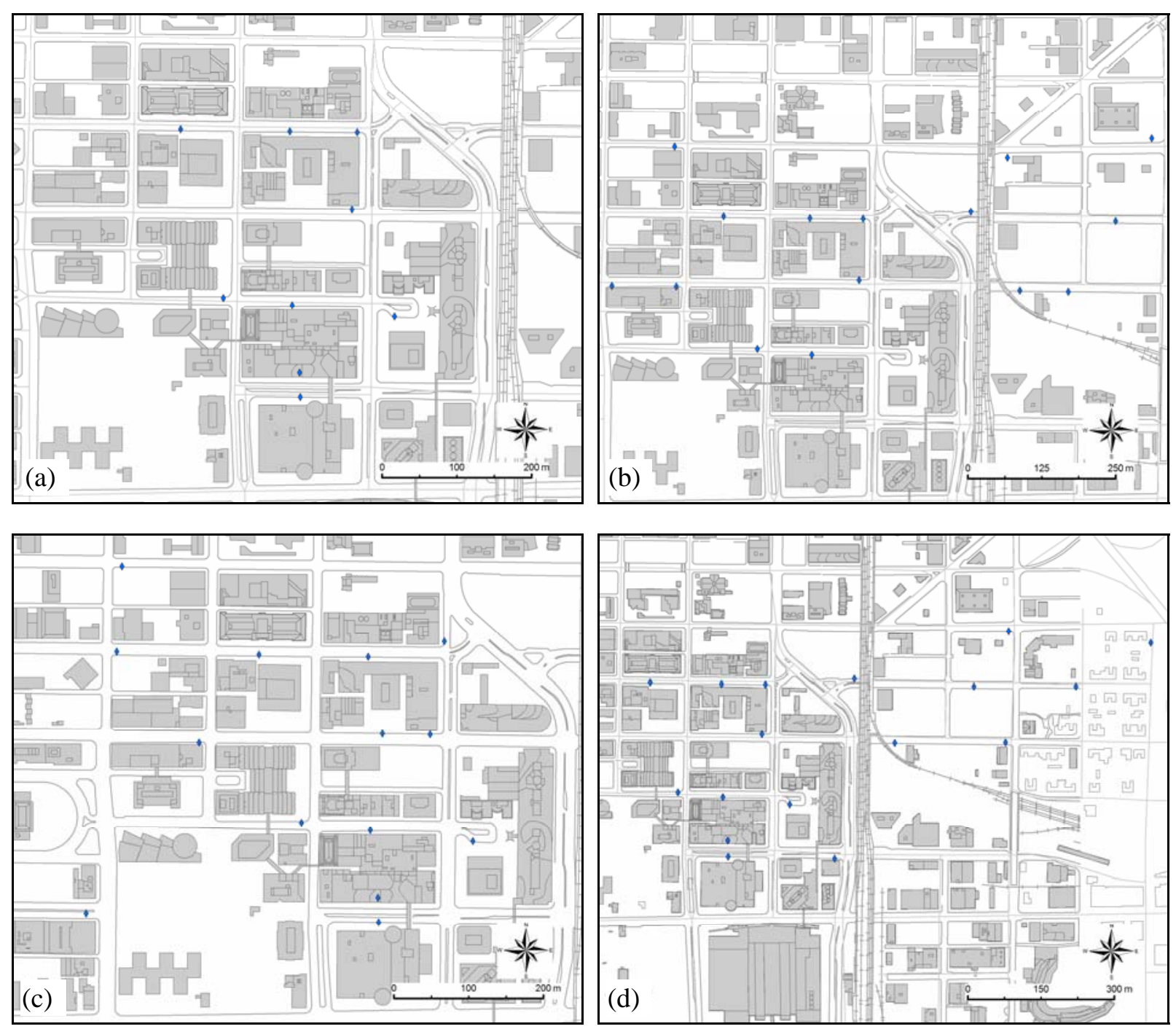

Figure A.8. ARLFRD Trace Gas Analyzer Instrument Locations During (a) IOPs 1, 3, 4, \& 6, (b) IOP 2, (c) IOP 5, (d) IOP 7, (e) IOP 8, (f) IOP 9, and (g) IOP 10. Refer to Table A.4 for instruments that were relocated during an IOP. 

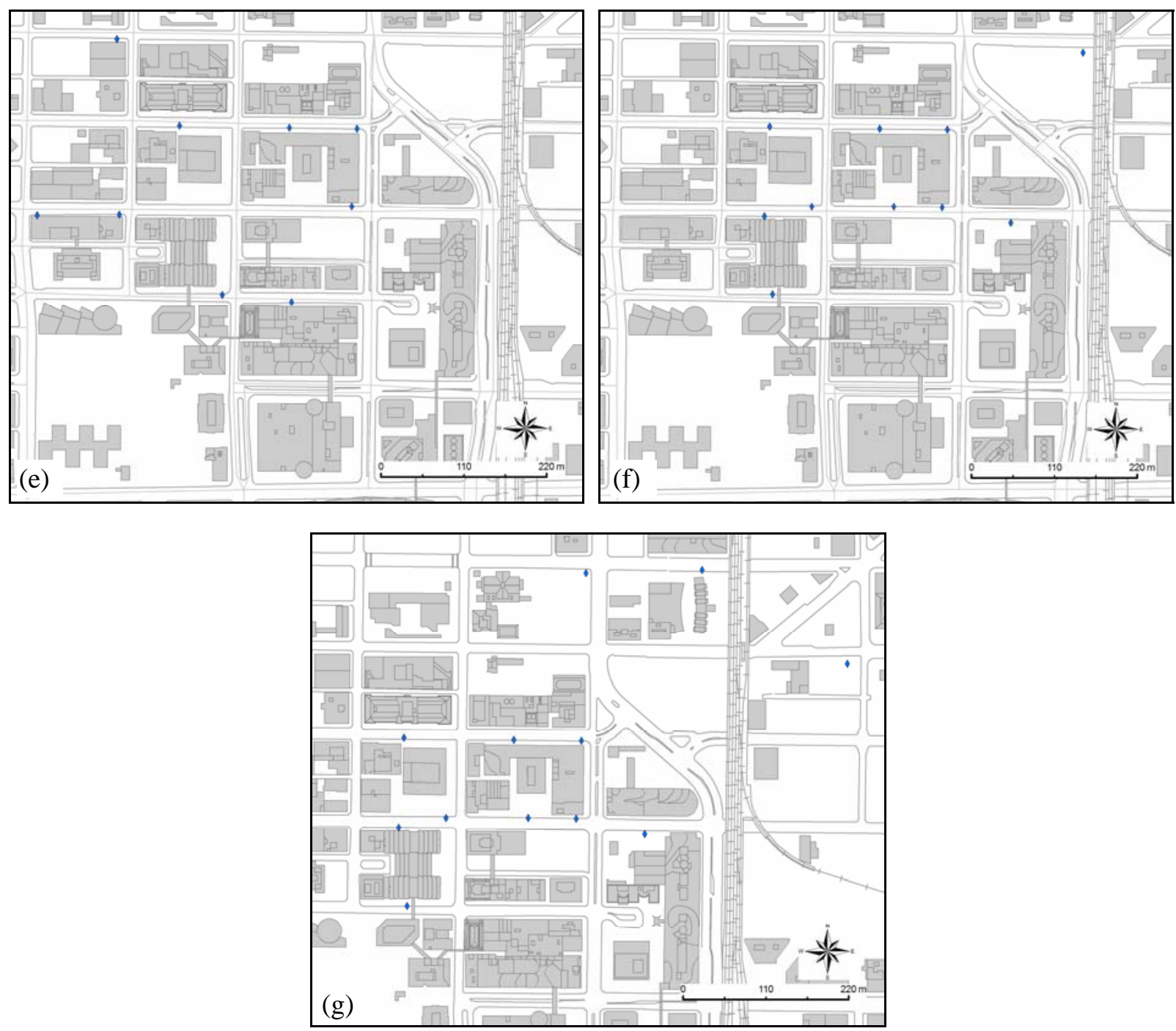

Figure A.8. (Contd)

Table A.5. ARLFRD $\mathrm{SF}_{6}$ Release Locations

\begin{tabular}{|l|l|c|c|c|c||}
\hline Release Name & Location Description & Latitude & Longitude & Easting & Northing \\
\hline \hline Westin (East) & Broadway across from Westin Hotel & 35.46727 & 97.51444 & 634790 & 3925877 \\
Westin & Broadway in front of the Westin Hotel & 35.46736 & 97.51462 & 634773 & 3925887 \\
\hline Botanical & $\begin{array}{l}\text { Robinson \& Sheridan E of Botanical } \\
\text { Gardens }\end{array}$ & 35.46626 & 97.51652 & 634603 & 3925763 \\
Park & S side of Park btwn Robinson \& Broadway & 35.46871 & 97.51556 & 634686 & 3926036 \\
\hline Fourth & N side of 4 & & \\
\hline
\end{tabular}




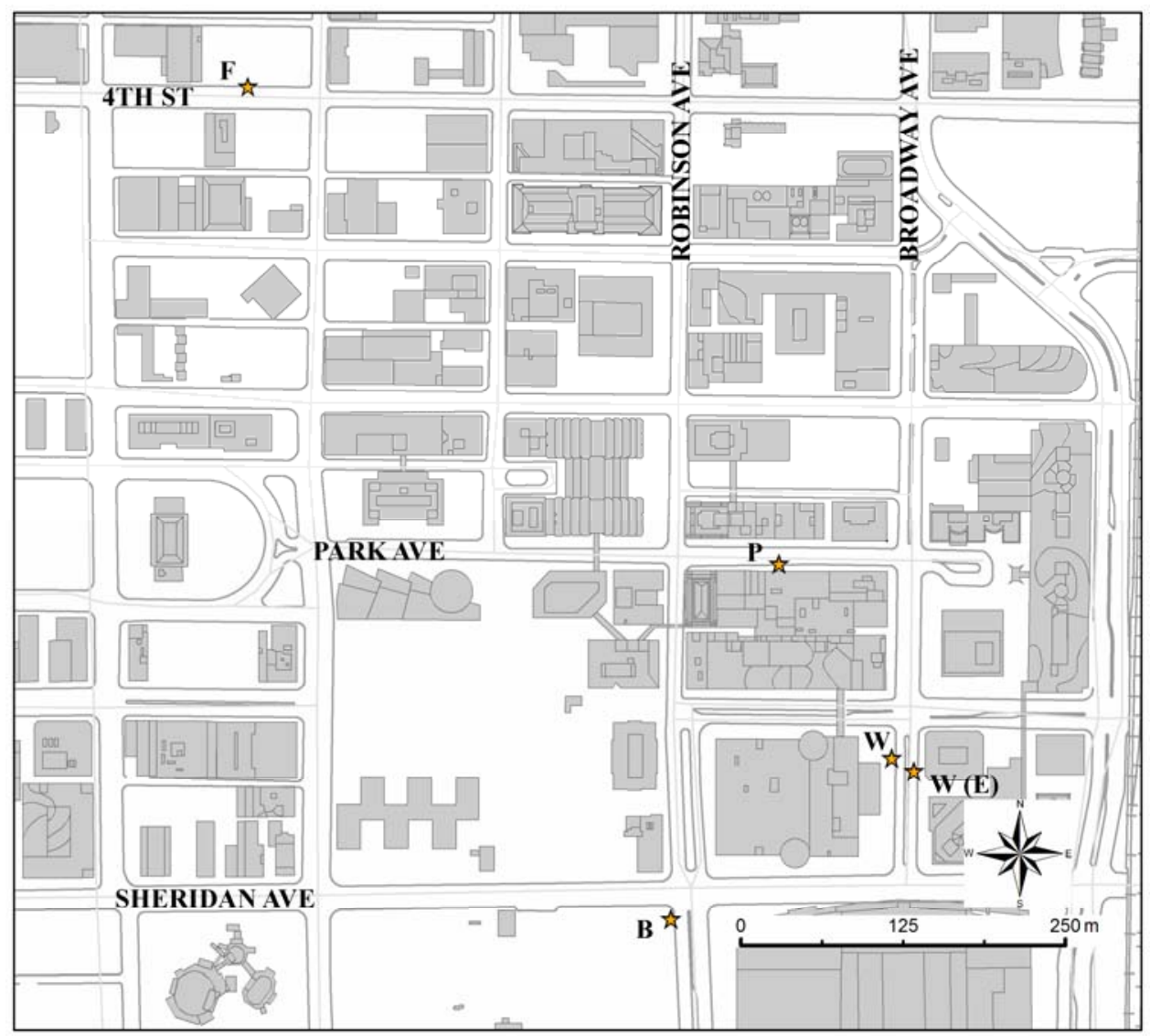

Figure A.9. ARLFRD SF 6 Release Locations: $\mathrm{W}(\mathrm{E})=$ Westin (East), $\mathrm{W}=$ Westin, $\mathrm{B}=$ Botanical, $\mathrm{P}=$ Park, and $\mathrm{F}=$ Fourth

Table A.6. ARLFRD Sodar Locations

\begin{tabular}{|l|l|c|c|c|c||}
\hline \hline Instrument & Location Description & Latitude & Longitude & Easting & Northing \\
\hline \hline Sodar & OK School of Science and Mathematics & 35.48147 & 97.50510 & 635613 & 3927465 \\
\hline
\end{tabular}




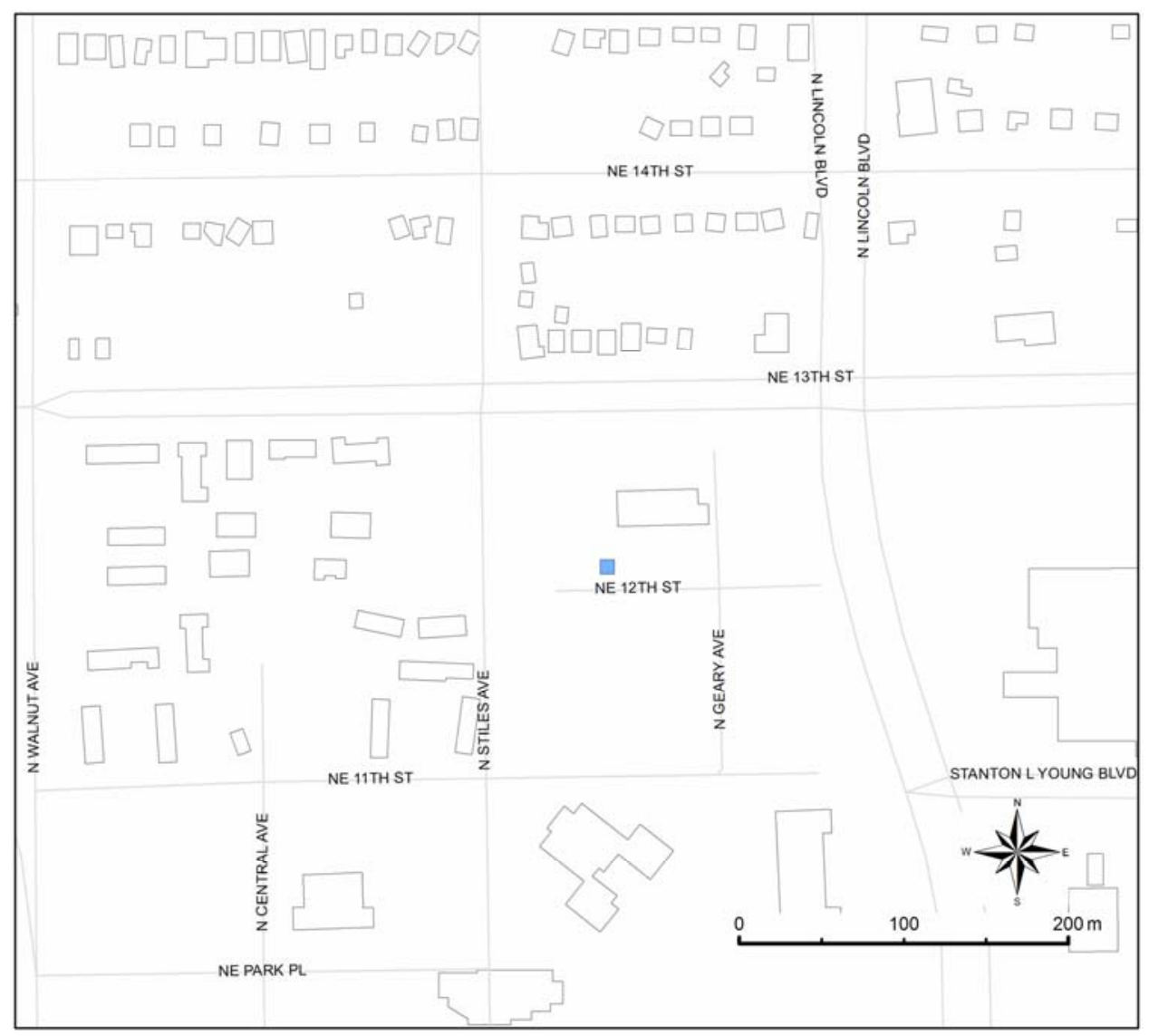

Figure A.10. ARLFRD Sodar Location

\section{A.4 Arizona State University}

Arizona State University deployed two towers and a lidar during this field study. One tower was in the heavily-instrumented Park Avenue street canyon, while the other (known as the energy tower) was northwest of the central business district. The ASU lidar was located about $3 \mathrm{~km}$ southeast of the central business district. The coordinates for the three ASU measurement sites are presented in Table A.7, while the locations are shown in Figures A.11 and A.12.

Table A.7. ASU Instrument Locations

\begin{tabular}{|l|l|c|c|c|c||}
\hline \hline Instrument & Location Description & Latitude & Longitude & Easting & Northing \\
\hline \hline sonics (3) / surface temp & Park Ave 28.5m W of Broadway & 35.46879 & 97.51488 & 634747 & 3926046 \\
\hline Sonic / energy & S of 11th btwn Walker \& Hudson & 35.47940 & 97.52003 & 634262 & 3927215 \\
\hline lidar & SW of 25th \& Akin & 35.43883 & 97.49222 & 636854 & 3922754 \\
\hline
\end{tabular}




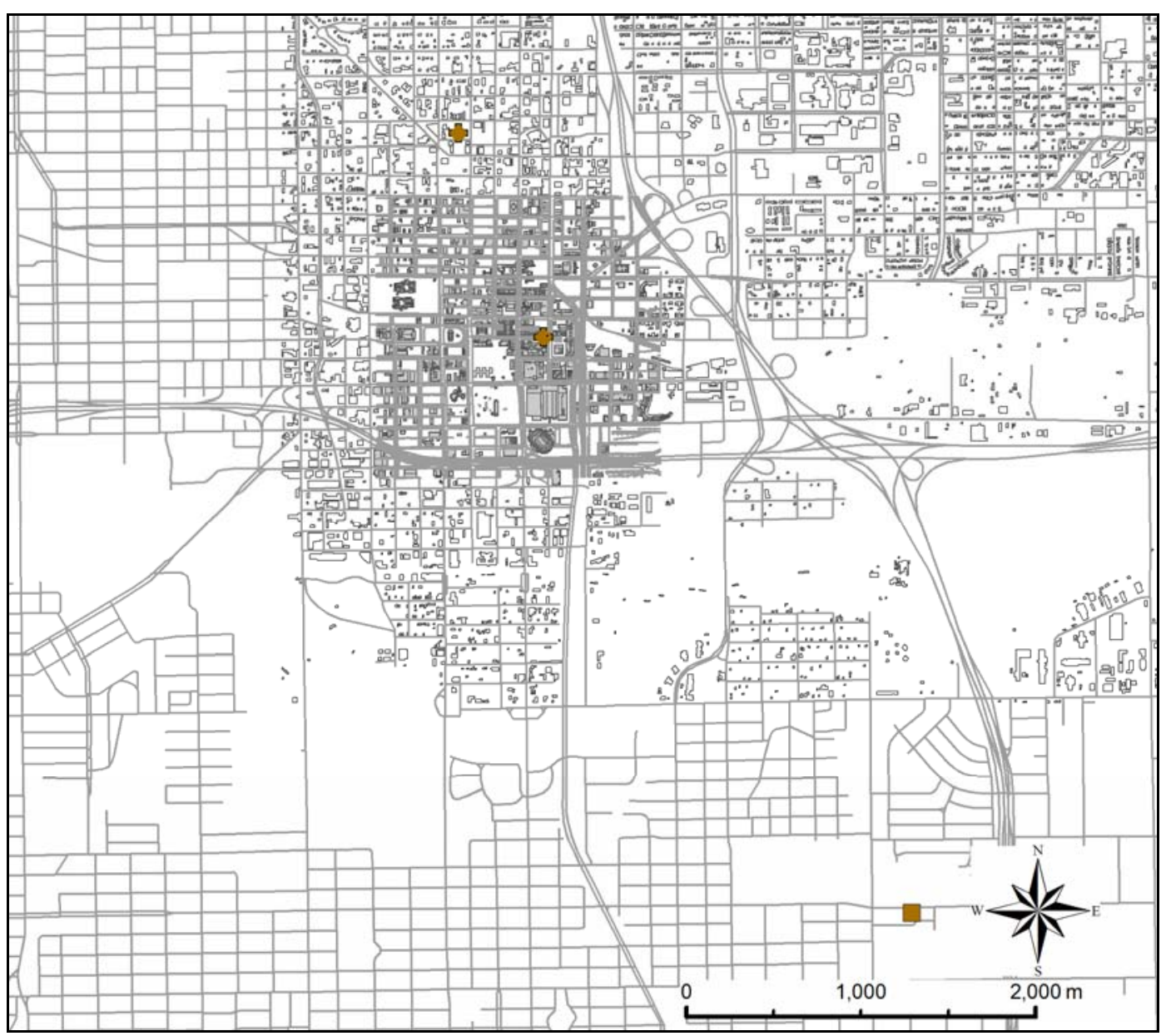

Figure A.11. Overview of ASU Instrument Locations 

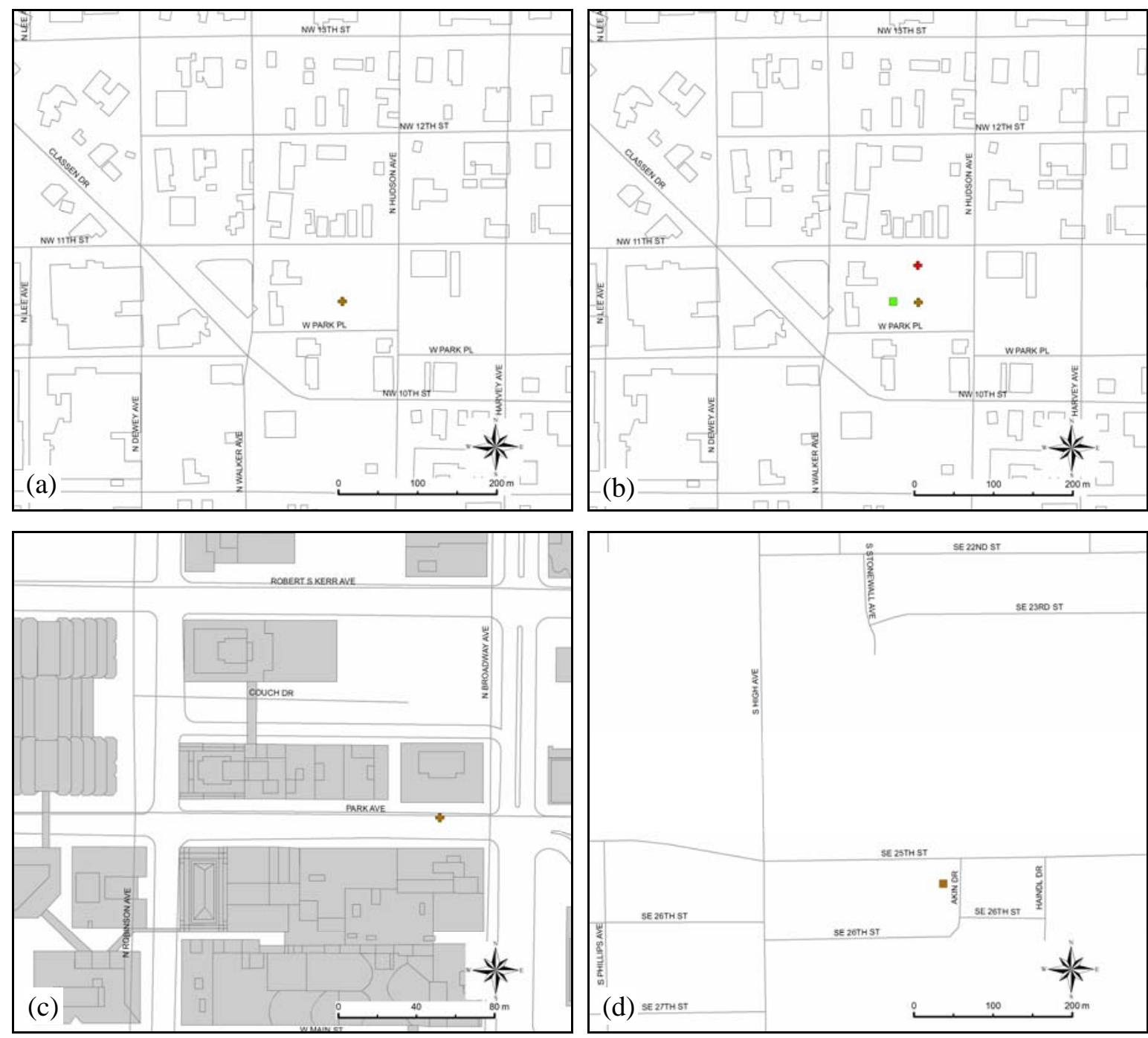

Figure A.12. ASU Instrument Locations: (a) Energy Tower, (b) Energy Tower with Neighboring Instrumentation Shown, (c) Park Tower, and (d) Lidar

\section{A.5 NOAA Air Resources Laboratory-Atmospheric Turbulence and Diffusion Division}

The NOAA Air Resources Laboratory Atmospheric Turbulence and Diffusion Division measured winds, energy fluxes, and pressure fluctuations continuously at several sites around Oklahoma City. The coordinates of each of the instrument sites are presented in Table A.8 and are shown on maps in Figures A.13 and A.14. 
Table A.8. ATDD Instrument Locations

\begin{tabular}{|l|l|c|c|c|c||}
\hline Instrument & Location Description & Latitude & Longitude & Easting & Northing \\
\hline \hline sonics (4) & Tower 1 - 11th St E of Walker & 35.47982 & 97.52003 & 634261 & 3927262 \\
\hline sonics (4) & $\begin{array}{l}\text { Tower 2 - OK School of Science \& Math. N of } \\
\text { 11th E of Stiles }\end{array}$ & 35.48093 & 97.50503 & 635620 & 3927406 \\
\hline energy flux & $\begin{array}{l}\text { Site A - Fred Jones Parking - Main \& Fred } \\
\text { Jones }\end{array}$ & 35.46848 & 97.52762 & 633592 & 3925994 \\
\hline energy flux & $\begin{array}{l}\text { Site B - OK School of Science \& Math - 10th } \\
\text { \& Lincoln }\end{array}$ & 35.48094 & 97.50515 & 635610 & 3927406 \\
\hline energy flux & Site C - Galleria Parking - Sheridan \& Hudson & 35.46772 & 97.51849 & 634421 & 3925922 \\
\hline microbarograph & Site 1 - S of 13th E of Stiles & 35.48213 & 97.50552 & 635574 & 3927538 \\
\hline microbarograph & Site 2 - N of 10th E of Walnut & 35.47833 & 97.50860 & 635301 & 3927113 \\
\hline microbarograph & Site 3 - W of Lincoln btwn 10th \& Park & 35.47885 & 97.50316 & 635793 & 3927177 \\
\hline
\end{tabular}

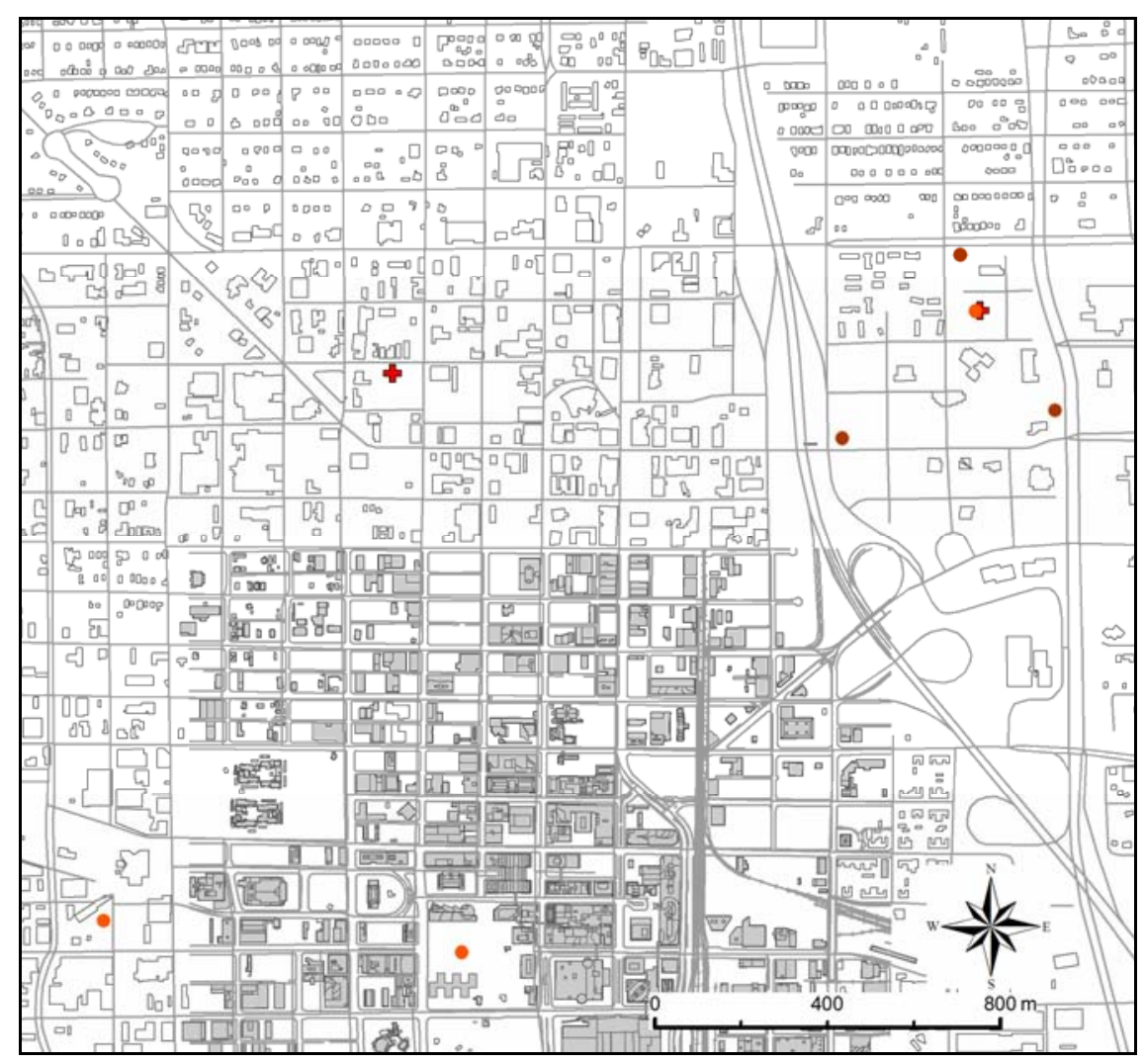

Figure A.13. Overview of ATDD Instrument Locations. Red plus-shaped markers represent the sonic anemometer towers, brown circular markers represent the micro-barograph pressure sites, and orange circular markers represent energy flux sites. 

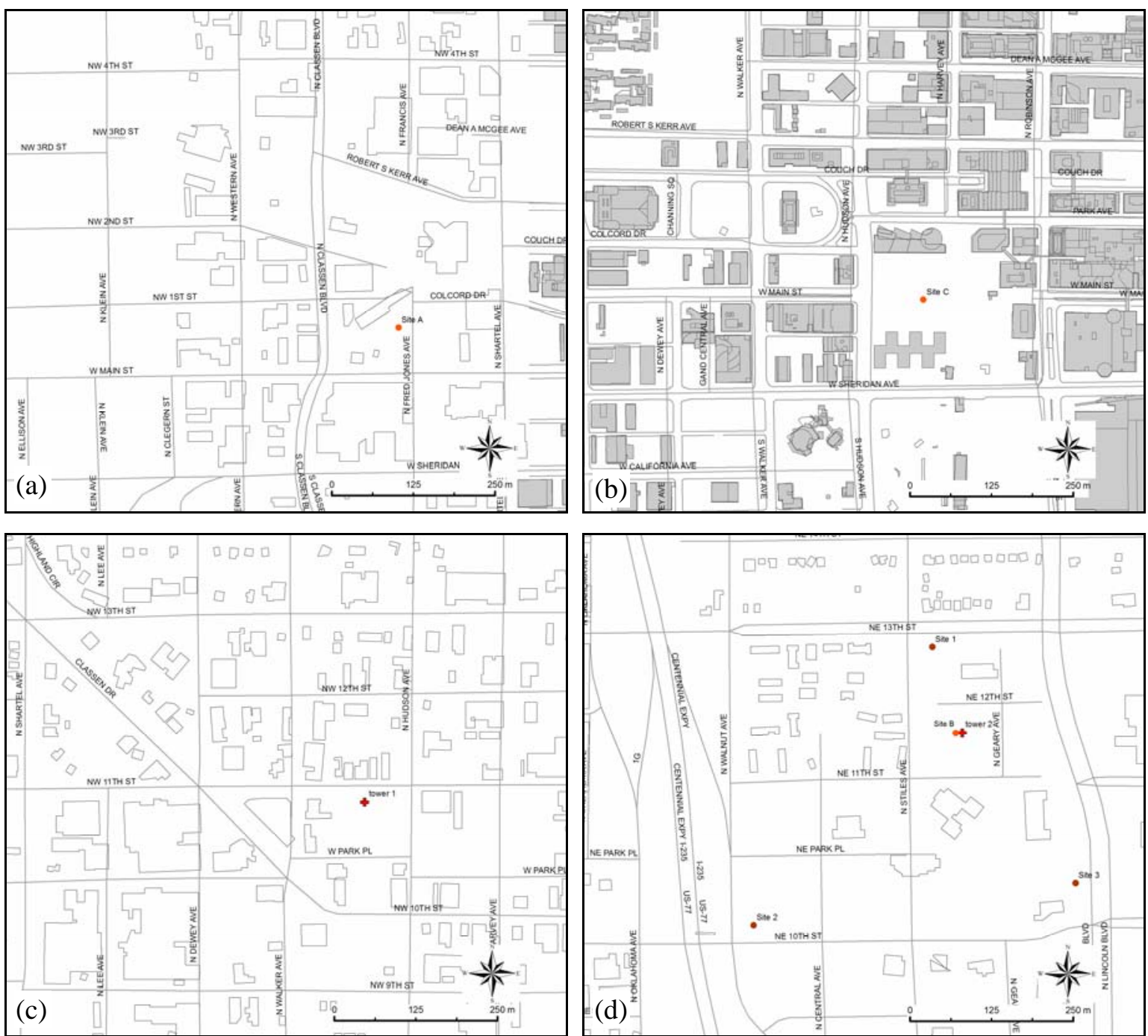

Figure A.14. ATDD Instrument Locations at (a) Energy Flux Site A, (b) Energy Flux Site C, (c) Sonic Tower 1, and (d) Energy Flux Site B and Micro-barograph Pressure Sites 1 Through 3

\section{A.6 Dugway Proving Ground}

During Joint Urban 2003, Dugway Proving Ground deployed 15 Portable Weather Information Display System (PWIDS) with propeller and vane anemometers and 20 Super PWIDS with 3D sonic anemometers. Most of these instruments were mounted on light or traffic poles at intersections in the central business district. Some of the Super PWIDS were co-located with the PWIDS for quality assurance. The PWIDS and Super PWIDS coordinates are presented in Table A.9, while their locations are shown in Figures A.15 through A.19.

DPG also had 2 profile sites; a sodar and radar were located north of the central business district, and a tethersonde was within the Park Avenue street canyon. The coordinates of the three profile instruments are presented in Table A.10 and locations are shown in Figures A.20 and A.21. 
Table A.9. DPG PWIDS and SuperPWIDS Locations

\begin{tabular}{|c|c|c|c|c|c|}
\hline Instrument & Location Description & Latitude & Longitude & Easting & Northing \\
\hline PWIDS 01 & NW corner of Hudson/Kerr & 35.46998 & 97.51967 & 634311 & 3926171 \\
\hline PWIDS 02 & SW corner of Robinson/Kerr & 35.46973 & 97.51646 & 634602 & 3926148 \\
\hline PWIDS 03 & NE corner of Broadway/Kerr & 35.46990 & 97.51431 & 634797 & 3926169 \\
\hline PWIDS 04 & SW corner of Robinson/Park & 35.46868 & 97.51648 & 634602 & 3926031 \\
\hline PWIDS 05 & SE corner of Broadway/Park & 35.46865 & 97.51427 & 634803 & 3926031 \\
\hline PWIDS 06 & SE corner of Hudson/Main & 35.46767 & 97.51933 & 634345 & 3925915 \\
\hline PWIDS 07 & NE corner of Robinson/Main & 35.46780 & 97.51638 & 634613 & 3925934 \\
\hline PWIDS 08 & NE corner of Broadway/Main & 35.46780 & 97.51437 & 634795 & 3925937 \\
\hline PWIDS 09 & Center island on S side of Gaylord/Main & 35.46733 & 97.51279 & 634939 & 3925886 \\
\hline PWIDS 10 & SW corner of Hudson/Sheridan & 35.46633 & 97.51964 & 634319 & 3925766 \\
\hline PWIDS 11 & SW corner of Robinson/Sheridan & 35.46632 & 97.51649 & 634605 & 3925769 \\
\hline PWIDS 12 & NW corner of Broadway/Sheridan & 35.46656 & 97.51468 & 634769 & 3925798 \\
\hline PWIDS 13 & SE corner of Gaylord/Sheridan & 35.46636 & 97.51278 & 634942 & 3925779 \\
\hline PWIDS 14 & S edge of Cox Convention Center roof & 35.46468 & 97.51456 & 634783 & 3925590 \\
\hline PWIDS 15 & 320 SW 5th St; Post Office roof [30m AGL] & 35.45971 & 97.51896 & 634392 & 3925033 \\
\hline SuperPWIDS 01 & SW corner of Robinson/4th & 35.47181 & 97.51639 & 634605 & 3926378 \\
\hline SuperPWIDS 02 & SE corner of Broadway/4th & 35.47179 & 97.51414 & 634809 & 3926379 \\
\hline SuperPWIDS 03 & SW corner of Robinson/McGee & 35.47078 & 97.51643 & 634603 & 3926264 \\
\hline SuperPWIDS 04 & SW corner of Broadway/McGee & 35.47072 & 97.51448 & 634780 & 3926260 \\
\hline SuperPWIDS 05 & SW corner of Robinson/Kerr & 35.46973 & 97.51646 & 634602 & 3926148 \\
\hline SuperPWIDS 06 & NE corner of Broadway/Kerr & 35.46990 & 97.51431 & 634797 & 3926169 \\
\hline SuperPWIDS 07 & NW corner of Robinson/Park & 35.46884 & 97.51656 & 634595 & 3926049 \\
\hline SuperPWIDS 08 & NE corner of Robinson/Park & 35.46885 & 97.51636 & 634613 & 3926050 \\
\hline SuperPWIDS 09 & SW corner of Robinson/Park & 35.46868 & 97.51648 & 634602 & 3926031 \\
\hline SuperPWIDS 10 & SE corner of Robinson/Park & 35.46872 & 97.51635 & 634614 & 3926036 \\
\hline SuperPWIDS 11 & NW corner of Broadway/Park & 35.46881 & 97.51462 & 634771 & 3926048 \\
\hline SuperPWIDS 12 & NE corner of Broadway/Park & 35.46886 & 97.51435 & 634795 & 3926054 \\
\hline SuperPWIDS 13 & SW corner of Broadway/Park & 35.46864 & 97.51455 & 634777 & 3926029 \\
\hline SuperPWIDS 14 & SE corner of Broadway/Park & 35.46865 & 97.51427 & 634803 & 3926031 \\
\hline SuperPWIDS 15 & Robinson; $75 \mathrm{ft} . \mathrm{N}$ of Robinson/Main & 35.46796 & 97.51639 & 634612 & 3925952 \\
\hline SuperPWIDS 16 & NE corner of Broadway/Main & 35.46780 & 97.51437 & 634795 & 3925937 \\
\hline SuperPWIDS 17 & SW corner of Robinson/Sheridan & 35.46632 & 97.51649 & 634605 & 3925769 \\
\hline SuperPWIDS 18 & NW corner of Broadway/Sheridan & 35.46656 & 97.51468 & 634769 & 3925798 \\
\hline SuperPWIDS 19 & NE corner of Broadway/Sheridan & 35.46657 & 97.51439 & 634795 & 3925800 \\
\hline SuperPWIDS 20 & NW corner of Robinson/Reno & 35.46435 & 97.51648 & 634609 & 3925551 \\
\hline
\end{tabular}




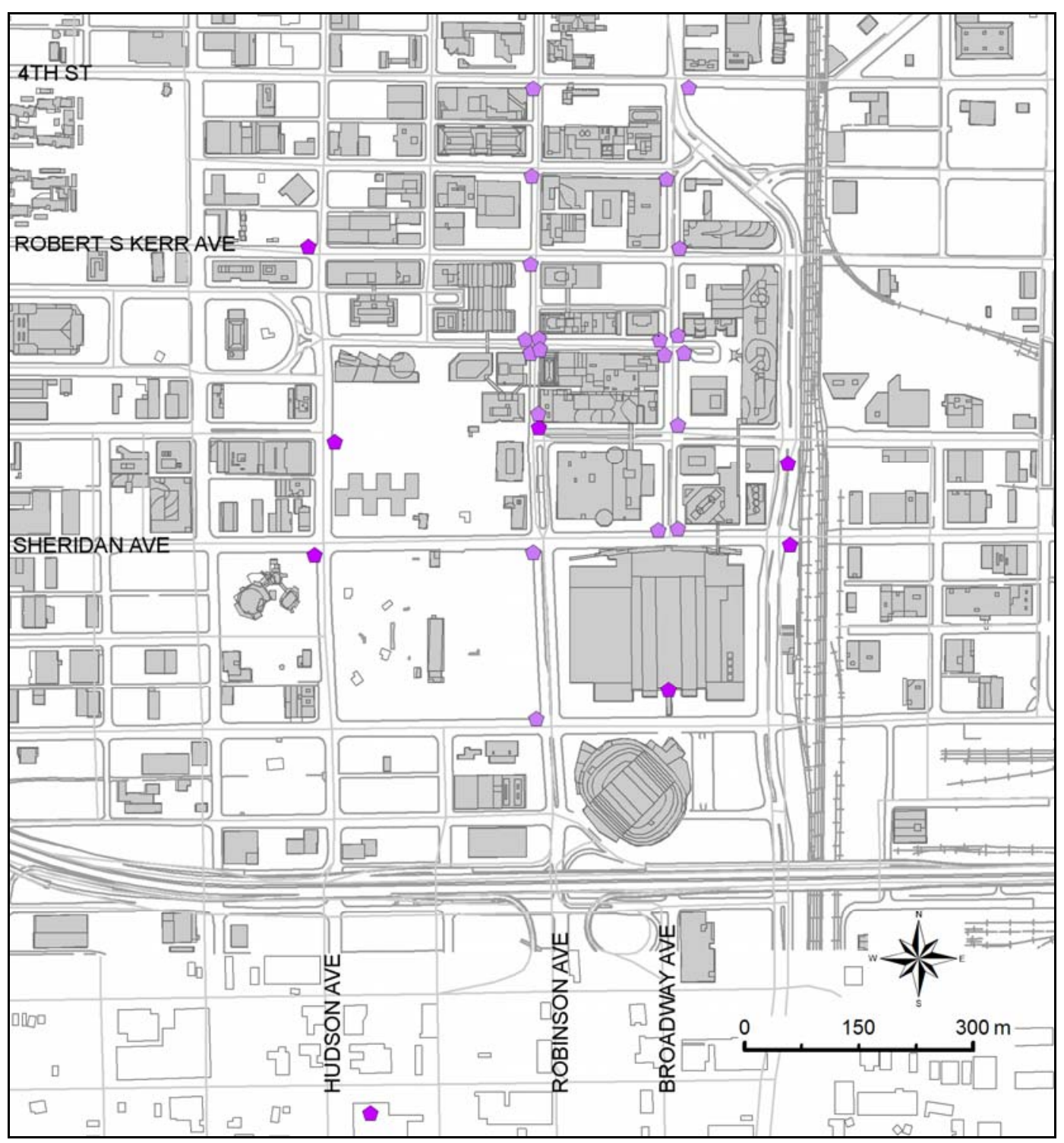

Figure A.15. Overview of DPG PWIDS and Super PWIDS Locations 


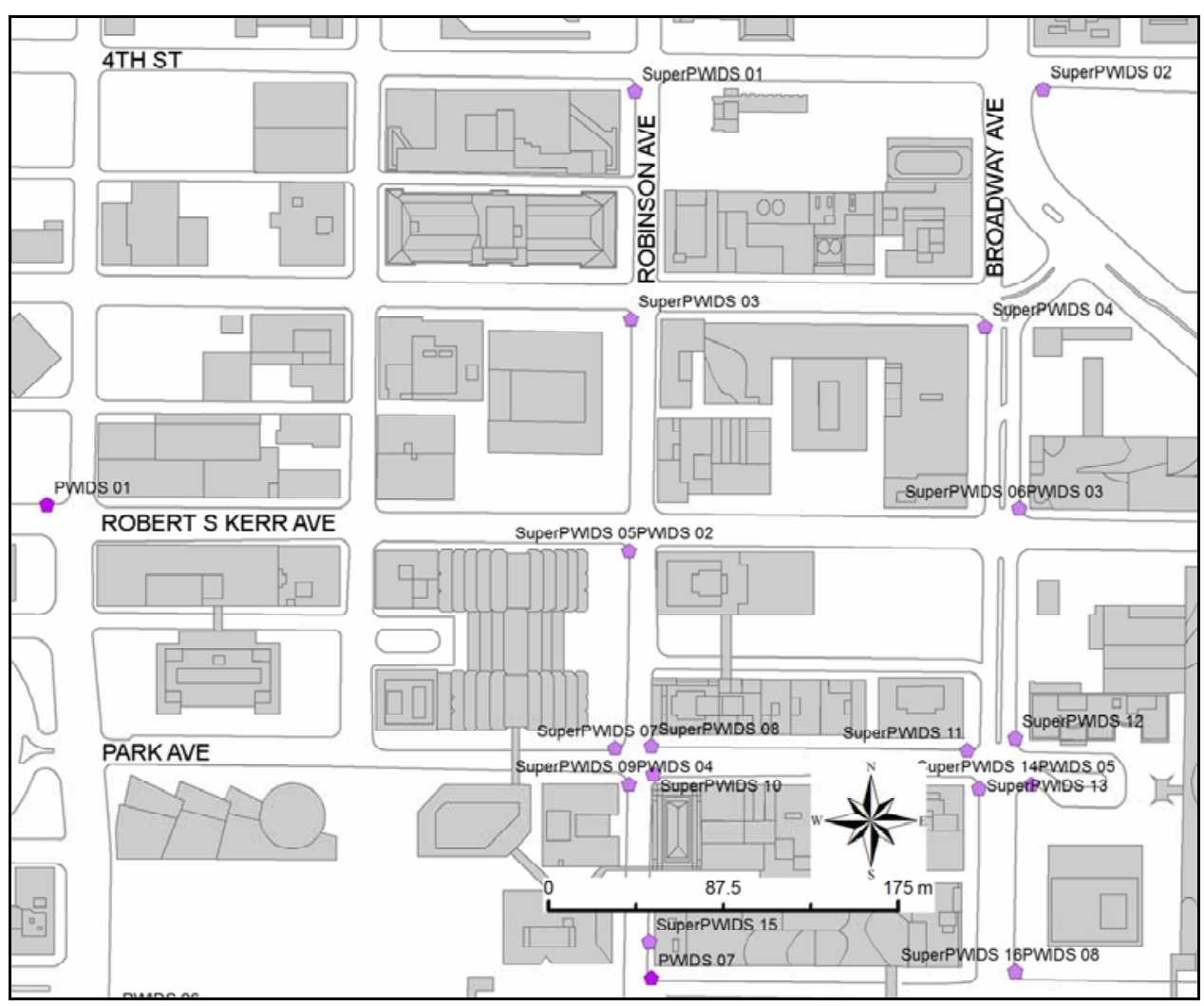

Figure A.16. DPG PWIDS and SuperPWIDS in the Northern Portion of the CBD

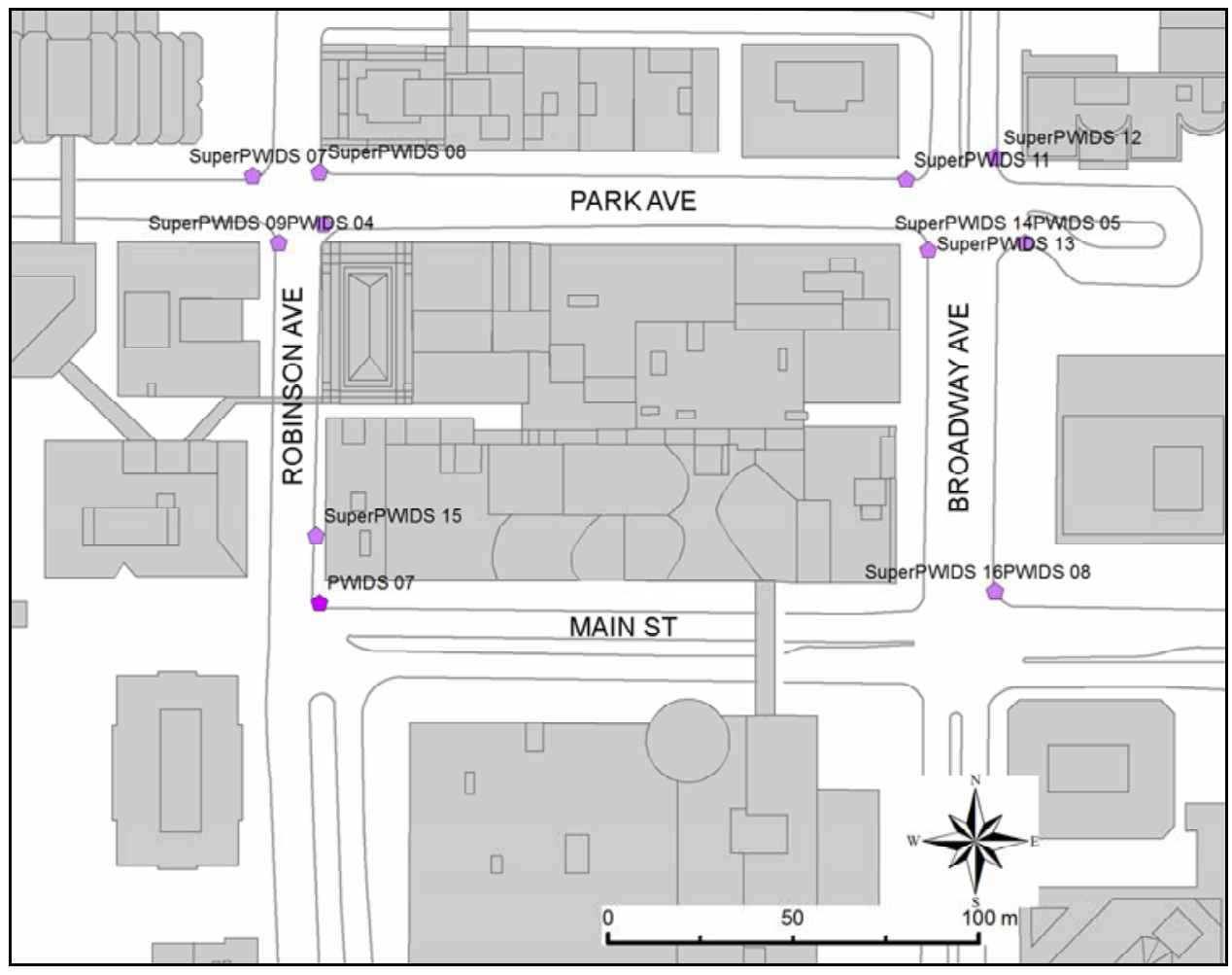

Figure A.17. DPG PWIDS and SuperPWIDS in the Central Portion of the CBD 


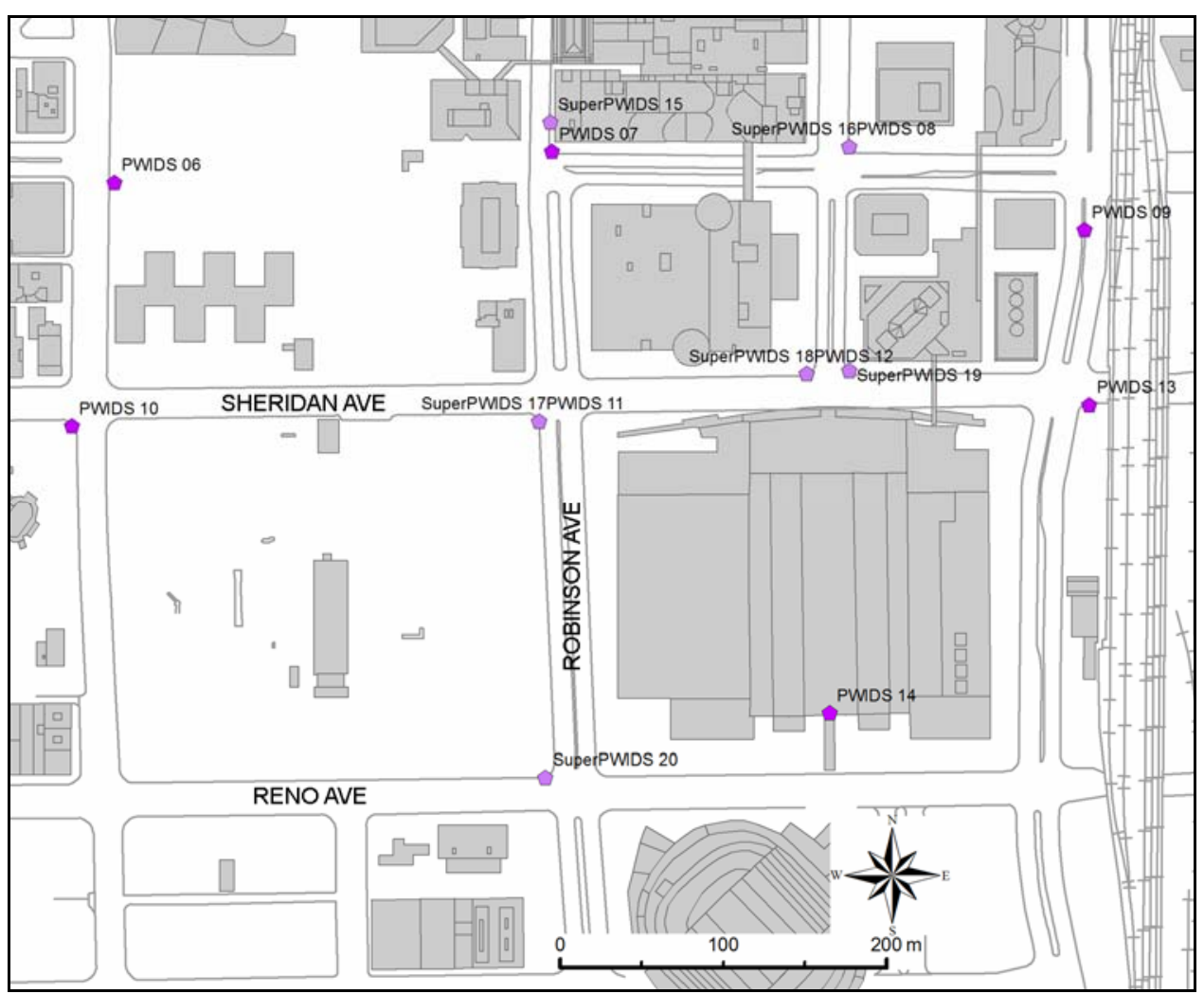

Figure A.18. DPG PWIDS and SuperPWIDS in the Southern Portion of the CBD

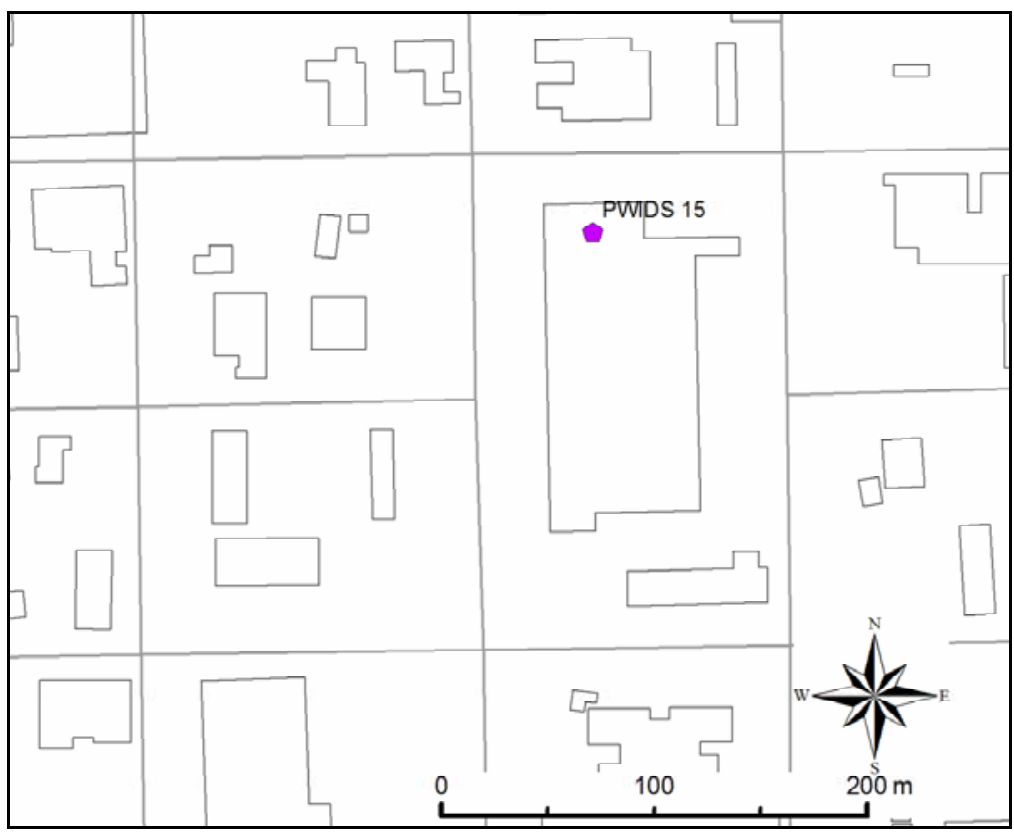

Figure A.19. DPG PWIDS on the Post Office Roof, South of the CBD 
Table A.10. DPG Profile Instrument Locations

\begin{tabular}{|c|c|c|c|c|c|}
\hline Instrument & Location Description & Latitude & Longitude & Easting & Northing \\
\hline Sodar & "S of $13^{\text {th }}$ btwn Harvey \& Robinson & 35.48203 & 97.51668 & 634562 & 3927512 \\
\hline FM-CW Radar & $\mathrm{S}$ of $13^{\text {th }}$ btwn Harvey $\&$ Robinson & 35.48217 & 97.51668 & 634562 & 3927527 \\
\hline Tethersonde & 101 Park Ave & 35.46884 & 97.51505 & 634732 & 3926051 \\
\hline
\end{tabular}

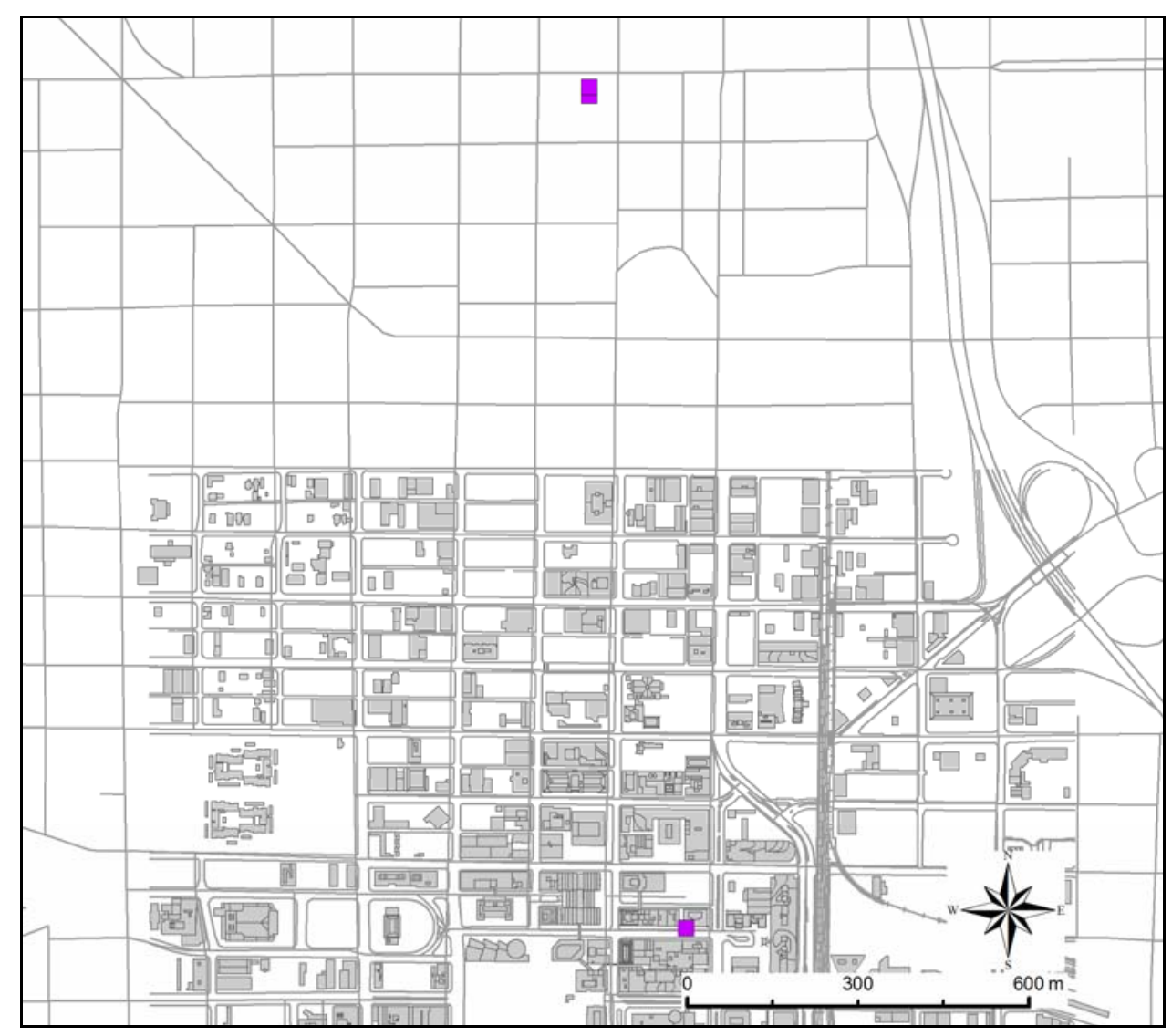

Figure A.20. Overview of DPG Profile Instrument Locations
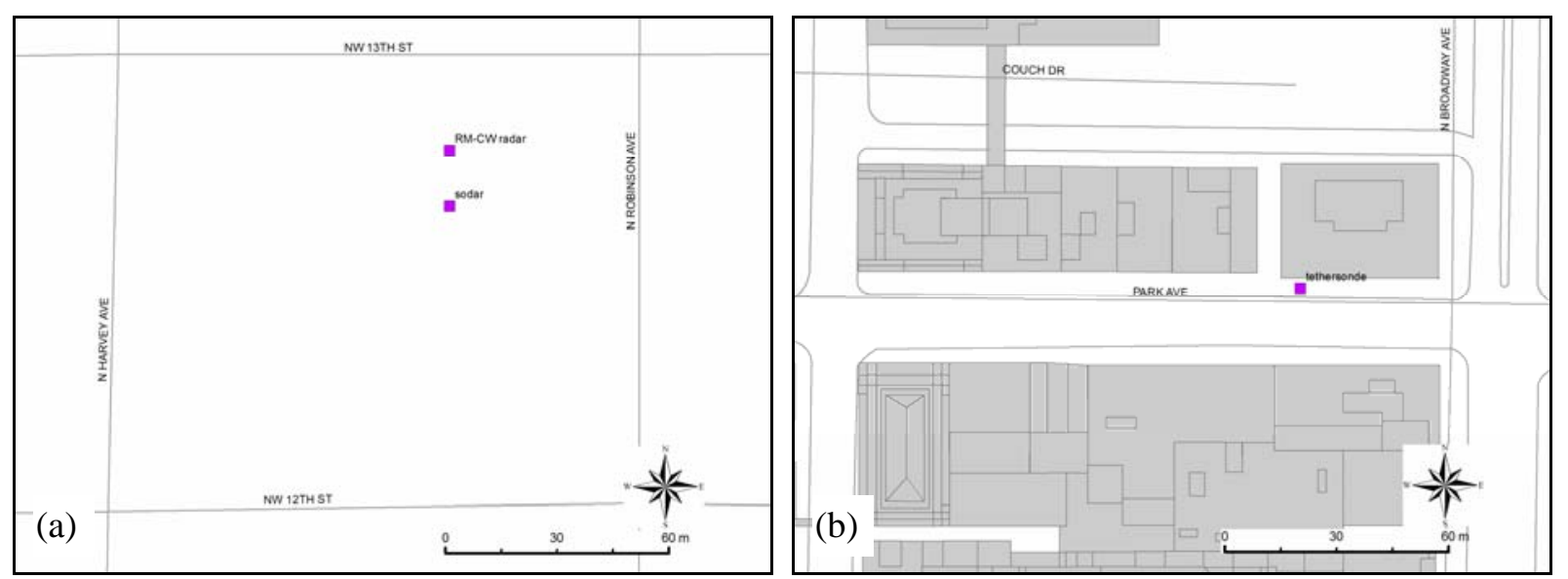

Figure A.21. DPG (a) Radar and Sodar, and (b) Tethersonde Locations 


\section{A.7 Defense Science and Technology Laboratory}

The Defense Science and Technology Laboratory had two towers and a portable sonic anemometer on a tripod in the Park Avenue street canyon. Due to some technical difficulties, the instrumentation was only functional during IOPs 5 through 10 . The coordinates of these instruments are presented in Table A.11 and the locations are shown in Figure A.22.

Table A.11. DSTL Sonic Anemometer Locations

\begin{tabular}{||l|l|c|c|c|c||}
\hline Instrument & Location Description & Latitude & Longitude & Easting & Northing \\
\hline \hline tower 1 - sonic 6 & $\begin{array}{l}\text { E end of Park on S side across from ASU } \\
\text { tower [3.5m agl] }\end{array}$ & 35.468730 & 97.514892 & 634746.2 & 3926038.9 \\
\hline tower 1 - sonic 2 & $\begin{array}{l}\text { E end of Park on S side across from ASU } \\
\text { tower [5m agl] }\end{array}$ & 35.468730 & 97.514892 & 634746.2 & 3926038.9 \\
\hline tower 1 - sonic 1 & $\begin{array}{l}\text { E end of Park on S side across from ASU } \\
\text { tower [6.5m agl] }\end{array}$ & 35.468730 & 97.514892 & 634746.2 & 3926038.9 \\
\hline tower 2 - sonic 5* & $\begin{array}{l}\text { W end of Park on N side across from UU } \\
\text { tower [3m agl] }\end{array}$ & 35.468819 & 97.515940 & 634651.0 & 3926047.3 \\
\hline tower 2 - sonic 4 & $\begin{array}{l}\text { W end of Park on N side across from UU } \\
\text { tower [5m agl] }\end{array}$ & 35.468819 & 97.515940 & 634651.0 & 3926047.3 \\
\hline tower 2 - sonic 3 & $\begin{array}{l}\text { W end of Park on N side across from UU } \\
\text { tower [10m agl] }\end{array}$ & 35.468819 & 97.515940 & 634651.0 & 3926047.3 \\
\hline Tri-pod - sonic 7 & $\begin{array}{l}\text { W end of Park on S side across from } \\
\text { LANL sonics [2m agl] }\end{array}$ & 35.468685 & 97.516232 & 634624.7 & 3926032.1 \\
\hline
\end{tabular}

* Sonic number 5 was replaced with sonic number 8 for IOPs 7 through 10

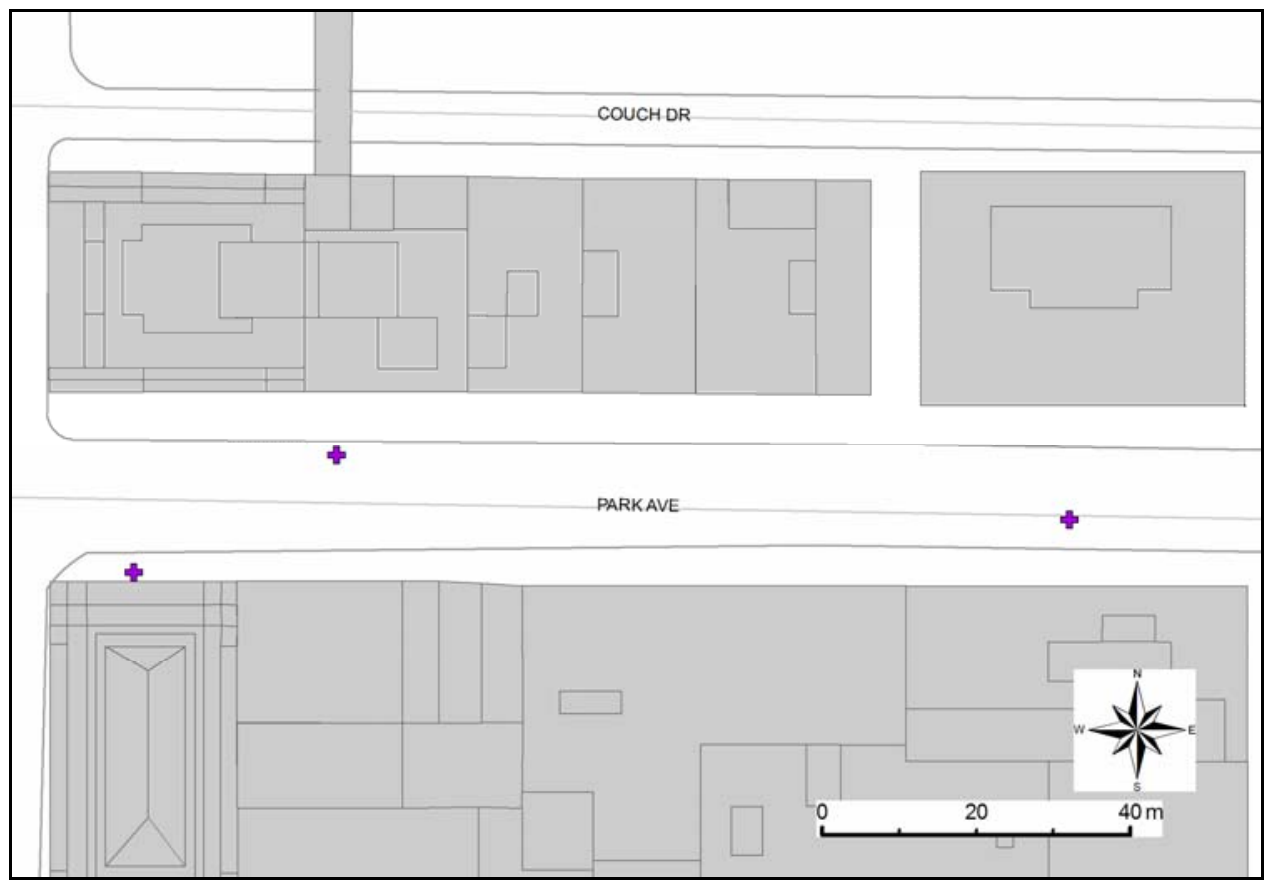

Figure A.22. DSTL Sonic Anemometer Locations in Park Ave 


\section{A.8 ITT Industries}

ITT Industries deployed five instantaneous tracer instruments called trace gas analyzers (TGAs) and 11 3D sonic anemometers during each IOP. The TGA coordinates for each IOP are presented in Table A.12 while all the TGA positions are shown in Figure A.23. The sonic anemometers were deployed in one of three configurations based on the release position for the IOP. Table A.13 presents the sonic anemometer coordinates for each of the three configurations and Figure A.24 shows all of these positions on a single map.

Table A.12. ITT Tracer Analyzer Locations

\begin{tabular}{|c|c|c|c|c|c|}
\hline Instrument & Location Description & Latitude & Longitude & Easting & Northing \\
\hline IOP1 - TGA1 & Harvey \& McGee & 35.47075 & 97.51800 & 634461 & 3926259 \\
\hline IOP1 - TGA2 & Robinson \& McGee & 35.47075 & 97.51648 & 634599 & 3926261 \\
\hline IOP1 - TGA3 & Park btwn Robinson \& Harvey & 35.46888 & 97.51718 & 634538 & 3926052 \\
\hline IOP1 - TGA4 & Courthouse grounds - Park \& Harvey & 35.46899 & 97.51809 & 634456 & 3926063 \\
\hline IOP1 - TGA5 & Near Sooner Statue - Robinson \& Couch & 35.46929 & 97.51624 & 634623 & 3926099 \\
\hline IOP2 - TGA1 & Harvey \& McGee & 35.47075 & 97.51800 & 634461 & 3926259 \\
\hline IOP2 - TGA2 & Robinson \& McGee & 35.47075 & 97.51648 & 634599 & 3926261 \\
\hline IOP2 - TGA3 & Park btwn Robinson \& Harvey & 35.46888 & 97.51718 & 634538 & 3926052 \\
\hline IOP2 - TGA4 & Courthouse grounds - Park \& Harvey & 35.46899 & 97.51809 & 634456 & 3926063 \\
\hline IOP2 - TGA5 & Kerr \& Robinson & 35.46973 & 97.51623 & 634623 & 3926148 \\
\hline IOP3 - TGA1 & Harvey \& McGee & 35.47075 & 97.51800 & 634461 & 3926259 \\
\hline IOP3 - TGA2 & Robinson \& McGee & 35.47075 & 97.51648 & 634599 & 3926261 \\
\hline IOP3 - TGA3 & Park btwn Robinson \& Harvey & 35.46888 & 97.51718 & 634538 & 3926052 \\
\hline IOP3 - TGA4 & Not Deployed & & & & \\
\hline IOP3 - TGA5 & Kerr \& Robinson & 35.46973 & 97.51623 & 634623 & 3926148 \\
\hline IOP4 - TGA1 & Harvey \& McGee & 35.47075 & 97.51800 & 634461 & 3926259 \\
\hline IOP4 - TGA2 & Robinson \& McGee & 35.47075 & 97.51648 & 634599 & 3926261 \\
\hline IOP4 - TGA3 & Park btwn Robinson \& Harvey & 35.46888 & 97.51718 & 634538 & 3926052 \\
\hline IOP4 - TGA4 & Courthouse grounds - Park \& Harvey & 35.46894 & 97.51824 & 634442 & 3926058 \\
\hline IOP4 - TGA5 & Kerr \& Robinson & 35.46973 & 97.51623 & 634623 & 3926148 \\
\hline IOP5 - TGA1 & Harvey \& McGee & 35.47075 & 97.51800 & 634461 & 3926259 \\
\hline IOP5 - TGA2 & Robinson \& McGee & 35.47075 & 97.51648 & 634599 & 3926261 \\
\hline IOP5 - TGA3 & Park btwn Robinson \& Harvey & 35.46888 & 97.51718 & 634538 & 3926052 \\
\hline IOP5 - TGA4 & Courthouse grounds - Park \& Harvey & 35.46894 & 97.51824 & 634442 & 3926058 \\
\hline IOP5 - TGA5 & Kerr \& Robinson & 35.46973 & 97.51623 & 634623 & 3926148 \\
\hline IOP6 - TGA1 & Harvey \& McGee & 35.47075 & 97.51800 & 634461 & 3926259 \\
\hline IOP6 - TGA2 & Robinson \& McGee & 35.47075 & 97.51648 & 634599 & 3926261 \\
\hline IOP6 - TGA3 & Park btwn Robinson \& Harvey & 35.46888 & 97.51718 & 634538 & 3926052 \\
\hline IOP6 - TGA4 & Courthouse grounds - Park \& Harvey & 35.46894 & 97.51824 & 634442 & 3926058 \\
\hline IOP6 - TGA5 & Kerr \& Robinson & 35.46973 & 97.51623 & 634623 & 3926148 \\
\hline IOP7 - TGA1 & Harvey \& McGee & 35.47075 & 97.51800 & 634461 & 3926259 \\
\hline IOP7 - TGA2 & Robinson \& McGee & 35.47075 & 97.51648 & 634599 & 3926261 \\
\hline IOP7 - TGA3 & Park btwn Robinson \& Harvey & 35.46888 & 97.51718 & 634538 & 3926052 \\
\hline IOP7 - TGA4 & Courthouse grounds - Park \& Harvey & 35.46898 & 97.51811 & 634454 & 3926062 \\
\hline IOP7 - TGA5 & Kerr \& Robinson & 35.46973 & 97.51623 & 634623 & 3926148 \\
\hline
\end{tabular}


Table A.12 (contd)

\begin{tabular}{|l|l|c|c|c|c||}
\hline Instrument & Location Description & Latitude & Longitude & Easting & Northing \\
\hline $\begin{array}{l}\text { IOP8 - TGA1 } \\
\text { IOP8 - TGA2 } \\
\text { IOP8 - TGA3 }\end{array}$ & $\begin{array}{l}\text { Harvey \& McGee } \\
\text { Not Deployed } \\
\text { Park btwn Robinson \& Harvey }\end{array}$ & 35.47075 & 97.51800 & 634461 & 3926259 \\
IOP8 - TGA4 & Courthouse grounds - Park \& Harvey & 35.46888 & 97.51718 & 634538 & 3926052 \\
\hline IOP8 - TGA5 & Kerr \& Robinson & 35.46973 & 97.51623 & 634623 & 3926148 \\
\hline IOP9 - TGA1 & 4th \& Broadway & 35.47173 & 97.51449 & 634778 & 3926372 \\
\hline IOP9 - TGA2 & Not Deployed & & & & \\
\hline IOP9 - TGA3 & 3td \& Gaylord & 35.47088 & 97.51318 & 634898 & 3926280 \\
\hline IOP9 - TGA4 & 4th \& Robinson & 35.47201 & 97.51650 & 634595 & 3926400 \\
\hline IOP9 - TGA5 & 4th \& Broadway & 35.47202 & 97.51772 & 634484 & 3926400 \\
\hline IOP10 - TGA1 & 4th \& Broadway & 35.47173 & 97.51449 & 634778 & 3926372 \\
\hline IOP10 - TGA2 & Not Deployed & 35.47088 & 97.51318 & 634898 & 3926280 \\
\hline IOP10 - TGA3 & 3td \& Gaylord & 35.47201 & 97.51650 & 634595 & 3926400 \\
\hline IOP10 - TGA4 & 4th \& Robinson & 35.47163 & 97.51267 & 634943 & 3926363 \\
\hline IOP10 - TGA5 & 4th \& RR tracks (during 2100) & 35.47157 & 97.51283 & 634929 & 3926357 \\
\hline IOP10 - TGA5 & 4th \& RR tracks (after 2100) & & & &
\end{tabular}

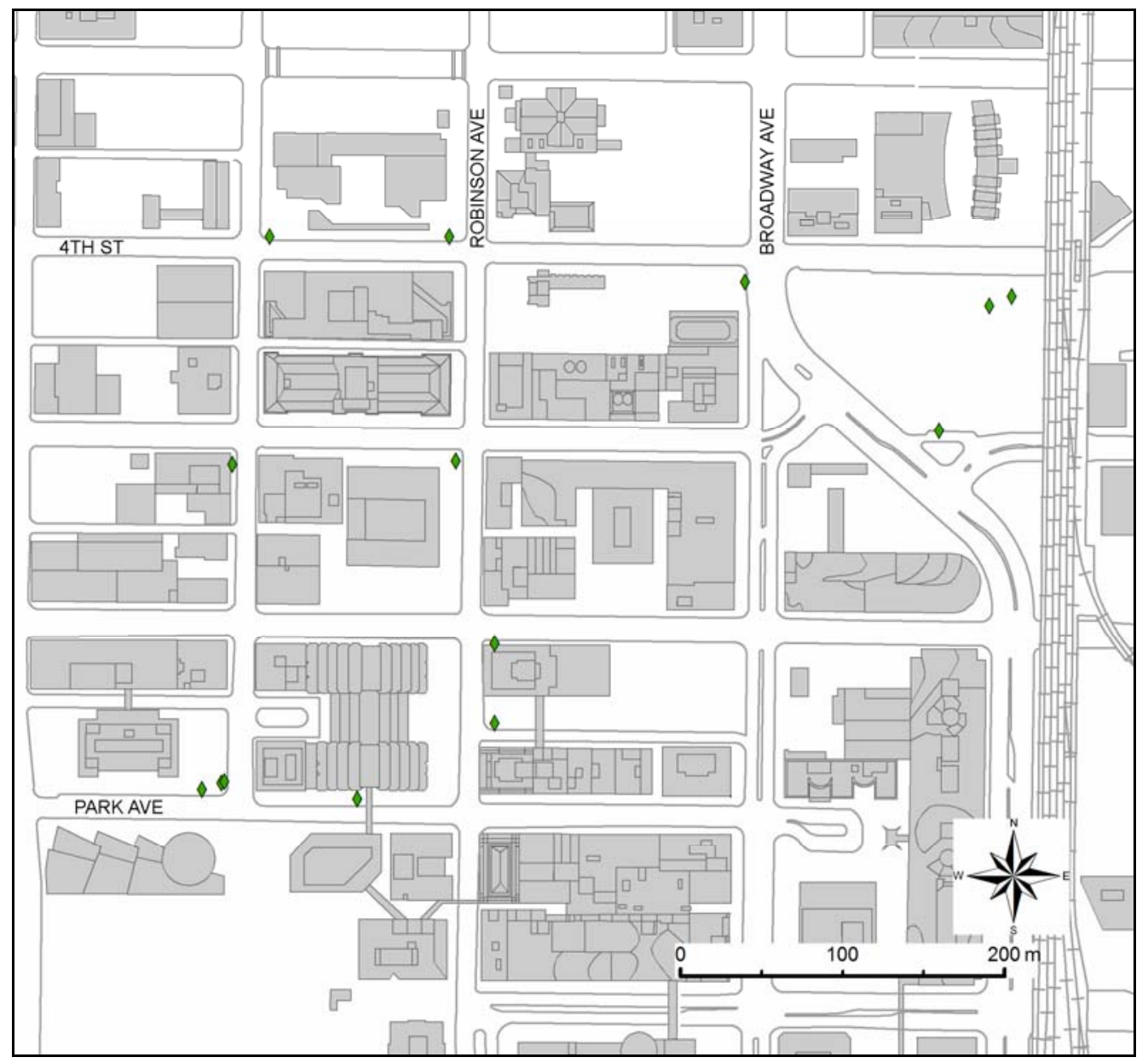

Figure A.23. Overview of All ITT TGA Locations 
Table A.13. ITT Sonic Anemometer Locations

\begin{tabular}{|c|c|c|c|c|c|}
\hline Instrument & Location Description & Latitude & Longitude & Easting & Northing \\
\hline sonic01 (botanical) & On Robinson (blvd) N of Sheridan & 35.46662 & 97.51634 & 634618 & 3925803 \\
\hline sonic02 (botanical) & N side of Sheridan W of Robinson & 35.46672 & 97.51688 & 634569 & 3925813 \\
\hline sonic03 (botanical) & rooftop - SW corner parking garage & 35.46672 & 97.51612 & 634638 & 3925814 \\
\hline sonic04 (botanical) & $\begin{array}{l}\text { W side Robinson } \mathrm{N} \text { of Sheridan (halfway } \\
\text { to Main) }\end{array}$ & 35.46704 & 97.51674 & 634581 & 3925849 \\
\hline sonic05 (botanical) & $\begin{array}{l}\text { Sheridan \& Robinson. SW of Robinson } \\
\text { Plaza }\end{array}$ & 35.46705 & 97.51724 & 634536 & 3925849 \\
\hline sonic06 (botanical) & $\begin{array}{l}\text { W side Robinson } \mathrm{N} \text { of Sheridan (halfway } \\
\text { to Main) }\end{array}$ & 35.46708 & 97.51656 & 634598 & 3925854 \\
\hline sonic07 (botanical) & $\begin{array}{l}\text { E side of Robinson } \mathrm{N} \text { of Sheridan } \\
\text { (halfway to Main) }\end{array}$ & 35.46703 & 97.51619 & 634631 & 3925849 \\
\hline sonic08 (botanical) & W side Robinson at the end of Main & 35.46773 & 97.51661 & 634592 & 3925926 \\
\hline sonic09 (botanical) & On Robinson (blvd) S of Main & 35.46757 & 97.51637 & 634614 & 3925908 \\
\hline sonic10 (botanical) & SE corner Main \& Robinson & 35.46750 & 97.51621 & 634629 & 3925901 \\
\hline sonic11 (botanical) & rooftop - NW corner pkg garage & 35.46748 & 97.51610 & 634639 & 3925899 \\
\hline sonic01 (westin) & Santa Fe Plaza N of Bank One Tower & 35.46848 & 97.51390 & 634837 & 3926012 \\
\hline sonic02 (westin) & S side Main W of Broadway & 35.46759 & 97.51493 & 634745 & 3925912 \\
\hline sonic03 (westin) & On Broadway (blvd) N of Main & 35.46788 & 97.51449 & 634784 & 3925945 \\
\hline sonic04 (westin) & N side Main E of Broadway & 35.46780 & 97.51385 & 634842 & 3925937 \\
\hline sonic05 (westin) & On Main (blvd) W of Broadway & 35.46768 & 97.51498 & 634740 & 3925922 \\
\hline sonic06 (westin) & $\begin{array}{l}\text { E side of Broadway S of Park W of Bank } \\
\text { One }\end{array}$ & 35.46824 & 97.51425 & 634805 & 3925985 \\
\hline sonic07 (westin) & $\begin{array}{l}\text { On Broadway (blvd) S of Park W of Bank } \\
\text { One }\end{array}$ & 35.46824 & 97.51446 & 634786 & 3925985 \\
\hline sonic08 (westin) & $\begin{array}{l}\text { On Main (blvd) E of Broadway S of Bank } \\
\text { One }\end{array}$ & 35.4 & 80 & 634847 & 3925920 \\
\hline sonic09 (westin) & S side Main W of Broadway & 35.46757 & 97.51470 & 634766 & 3925911 \\
\hline sonic10 (westin) & N side Main W of Broadway & 35.46777 & 97.51482 & 634754 & 3925932 \\
\hline sonic11 (westin) & $\mathrm{N}$ side Main $\mathrm{E}$ of Broadway & 35.46785 & 97.51358 & 634867 & 3925943 \\
\hline sonic01 (park) & $\begin{array}{l}\text { W side Broadway near Alley (NE corner } \\
\text { of Sonic Bldg) }\end{array}$ & 35.46912 & 97.51457 & 634775 & 3926083 \\
\hline sonic02 (park) & E side Broadway N of Park & 35.46896 & 97.51433 & 634797 & 3926065 \\
\hline sonic03 (park) & N side Park E of Broadway & 35.46881 & 97.51414 & 634814 & 3926049 \\
\hline sonic04 (park) & W side Broadway S of Park & 35.46845 & 97.51457 & 634776 & 3926008 \\
\hline sonic05 (park) & E side Broadway S of Park & 35.46843 & 97.51425 & 634805 & 3926006 \\
\hline sonic06 (park) & $\begin{array}{l}\text { E of Broadway S of Park N of Bank One } \\
\text { Bldg }\end{array}$ & 35.46842 & 97.51406 & 634822 & 3926006 \\
\hline sonic07 (park) & $\begin{array}{l}\text { E of Broadway S of Park N of Bank One } \\
\text { Bldg }\end{array}$ & 35.46842 & 97.51376 & 634849 & 3926006 \\
\hline sonic08 (park) & $\begin{array}{l}\text { W of Broadway N of Park N of Sonic } \\
\text { Bldg (alley) }\end{array}$ & 35.46923 & 97.51477 & 634756 & 3926094 \\
\hline sonic09 (park) & W side Broadway $\mathrm{N}$ of Alley $\mathrm{N}$ of Park & 35.46922 & 97.51461 & 634771 & 3926094 \\
\hline sonic10 (park) & E of Broadway N of Park & 35.46920 & 97.51401 & 634825 & 3926092 \\
\hline sonic11 (park) & E of Broadway N of Park & 35.46921 & 97.51426 & 634803 & 3926093 \\
\hline
\end{tabular}




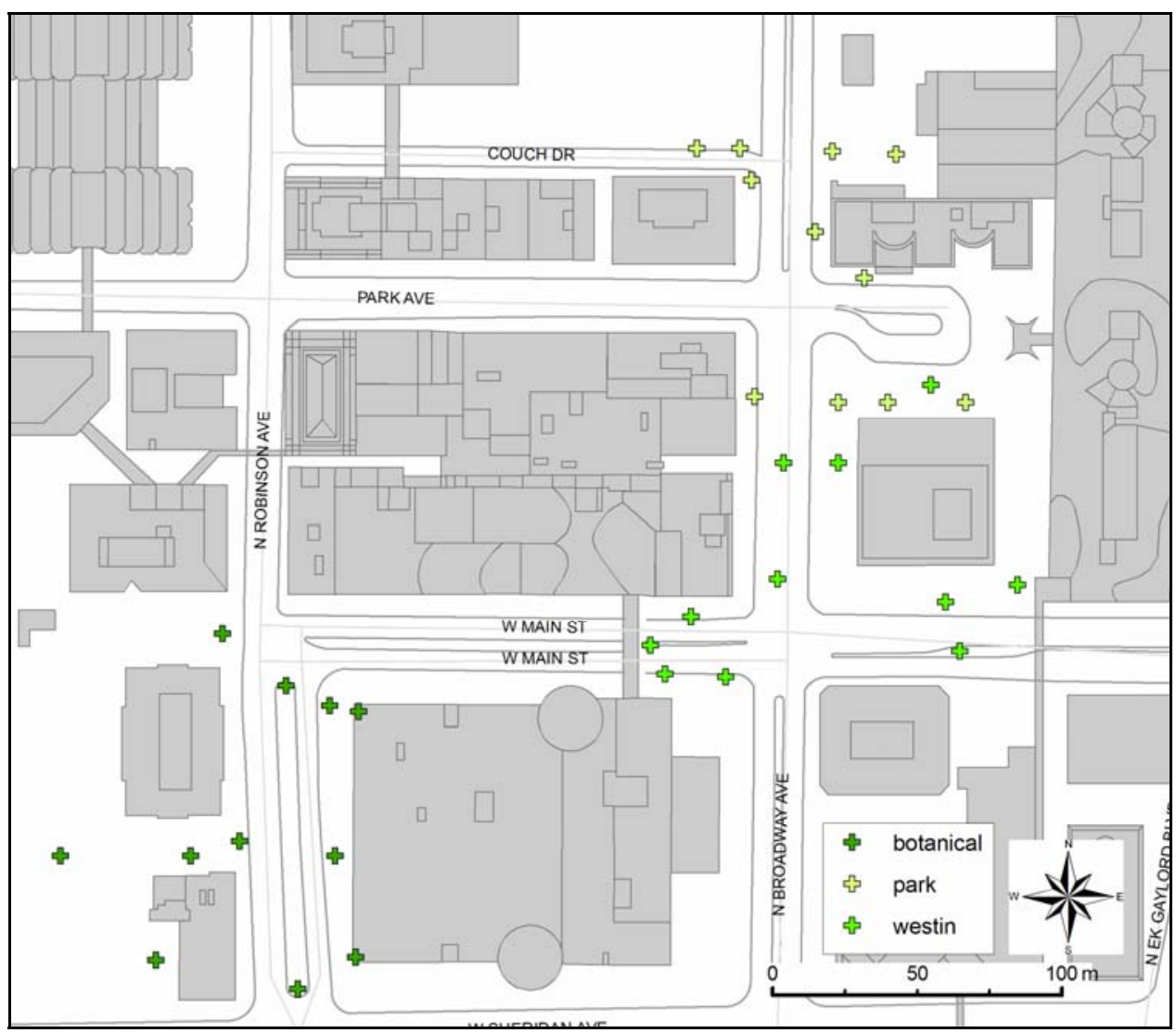

Figure A.24. ITT Sonic Locations for All IOPs. The dark green markers represent the deployment configuration for the Botanical release, the light green represents the deployment for the Park Avenue release, and the bright green represents deployment for the Westin release.

\section{A.9 Indiana University}

The Indiana University deployed a number of sonic anemometers and energy instrumentation at several sites about $6 \mathrm{~km}$ south of downtown Oklahoma City. Table A.14 presents the coordinates for each site, while Figure A.25 shows the locations on a map. Additional details about the instruments and data can be found at the following website: http://www.indiana.edu/ muhd/okcWeb/index.htm.

Table A.14. IU Sonic and Energy Tower Locations

\begin{tabular}{|c|c|c|c|c|c|}
\hline Instrument & Location Description & Latitude & Longitude & Easting & Northing \\
\hline sonics (2), energy & $\mathrm{BH}$ - Brick House & 35.40473 & 97.51338 & 634990 & 3918943 \\
\hline energy & BHB - Brich House Building & 35.40433 & 97.51418 & 634918 & 3928897 \\
\hline sonic (1), energy & GR - Grass & 35.41287 & 97.51137 & 635159 & 3919848 \\
\hline sonic (1), energy & GR-TM - Grass at Tyler Media & 35.41522 & 97.51063 & 635222 & 3920109 \\
\hline sonics (2), energy & TMA - Tyler Media (A) & 35.41505 & 97.51008 & 635272 & 3920091 \\
\hline sonics (2), energy & TMB - Tyler Media (B) & 35.41505 & 97.51008 & 635272 & 3920091 \\
\hline sonic (1), energy & WH - Wood House & 35.41047 & 97.51005 & 635283 & 3919583 \\
\hline energy & WHB - Wood House Building & 35.41305 & 97.51134 & 635162 & 3929868 \\
\hline
\end{tabular}




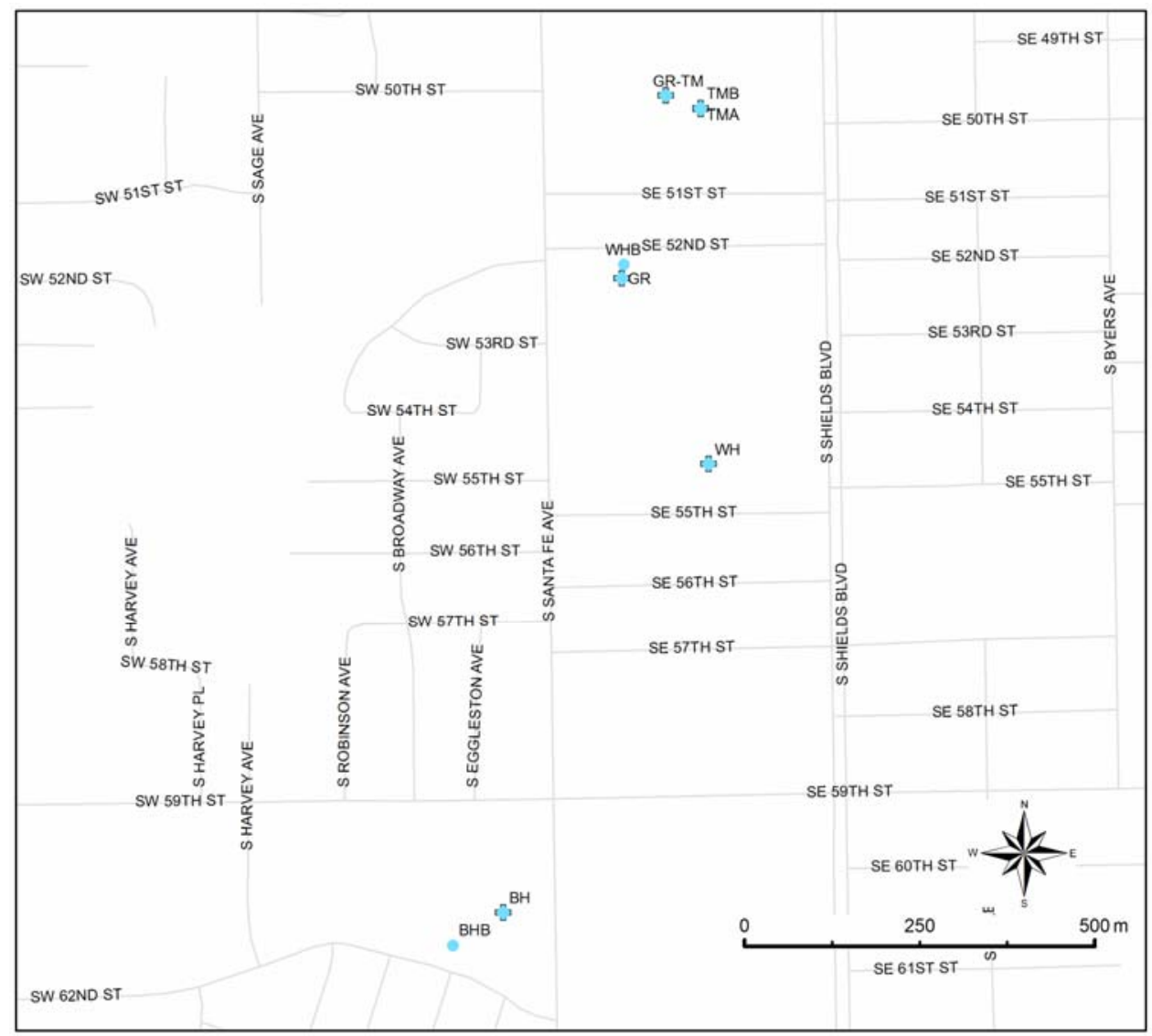

Figure A.25. IU Energy and Sonic Tower Locations

\section{A.10 Los Alamos National Laboratory}

Los Alamos National Laboratory deployed a number of 3D and 2D sonic anemometers in the Park Avenue street canyon in Oklahoma City. The 2D sonics were deployed during each IOP, while the 3D sonics collected data continuously through the month. The coordinates and locations of these instruments are presented in Table A.15 and Figure A.26. 
Table A.15. LANL Sonic Anemometer Locations

\begin{tabular}{||l|l|c|c|c|c||}
\hline Instrument & Location Description & Latitude & Longitude & Easting & Northing \\
\hline \hline 3D sonic (yellow) & 100 Park N Rooftop Overhang [45.3m agl] & 35.468662 & 97.514757 & 634758.6 & 3926031.5 \\
\hline 3D sonic (red) & 100 Park Rooftop Flagpole [47.7m agl] & 35.468633 & 97.514673 & 634766.2 & 3926028.4 \\
\hline & $\begin{array}{l}\text { Park Avenue \& Robinson Avenue on tripod } \\
\text { [2.2m agl] }\end{array}$ & 35.468850 & 97.516217 & 634625.8 & 3926050.4 \\
\hline 3D sonic (white) & $\begin{array}{l}\text { Sonic Building NW Rooftop Overhang } \\
\text { [47.5m agl] }\end{array}$ & 35.469129 & 97.515117 & 634725.1 & 3926082.9 \\
\hline 3D sonic (black) & $\begin{array}{l}\text { Sonic Building SW Rooftop Overhang } \\
\text { [47.5m agl] }\end{array}$ & 35.468852 & 97.515090 & 634728.0 & 3926052.2 \\
\hline 3D sonic (green) & $\begin{array}{l}\text { Sonic Building SE Rooftop Overhang } \\
\text { [47.5m agl] }\end{array}$ & 35.468846 & 97.514651 & 634767.9 & 3926052.1 \\
\hline 3D sonic 6 (blue) & S side Park W of Broadway [2.1m agl] & 35.468660 & 97.514720 & 634761.9 & 3926031.4 \\
\hline 2D sonic (white) & S side Park W of Broadway [2.05m agl] & 35.468660 & 97.514778 & 634756.7 & 3926031.3 \\
\hline 2D sonic (black) & N side Park W of Broadway [2.1m agl] & 35.468854 & 97.514719 & 634761.7 & 3926052.9 \\
\hline 2D sonic (yellow) & N side Park W of Broadway [2.1m agl] & 35.468855 & 97.514777 & 634756.4 & 3926052.9 \\
\hline 2D sonic (red) & N side Park E of Robinson [2.1m agl] & 35.468890 & 97.516216 & 634625.8 & 3926054.8 \\
\hline 2D sonic (green)
\end{tabular}

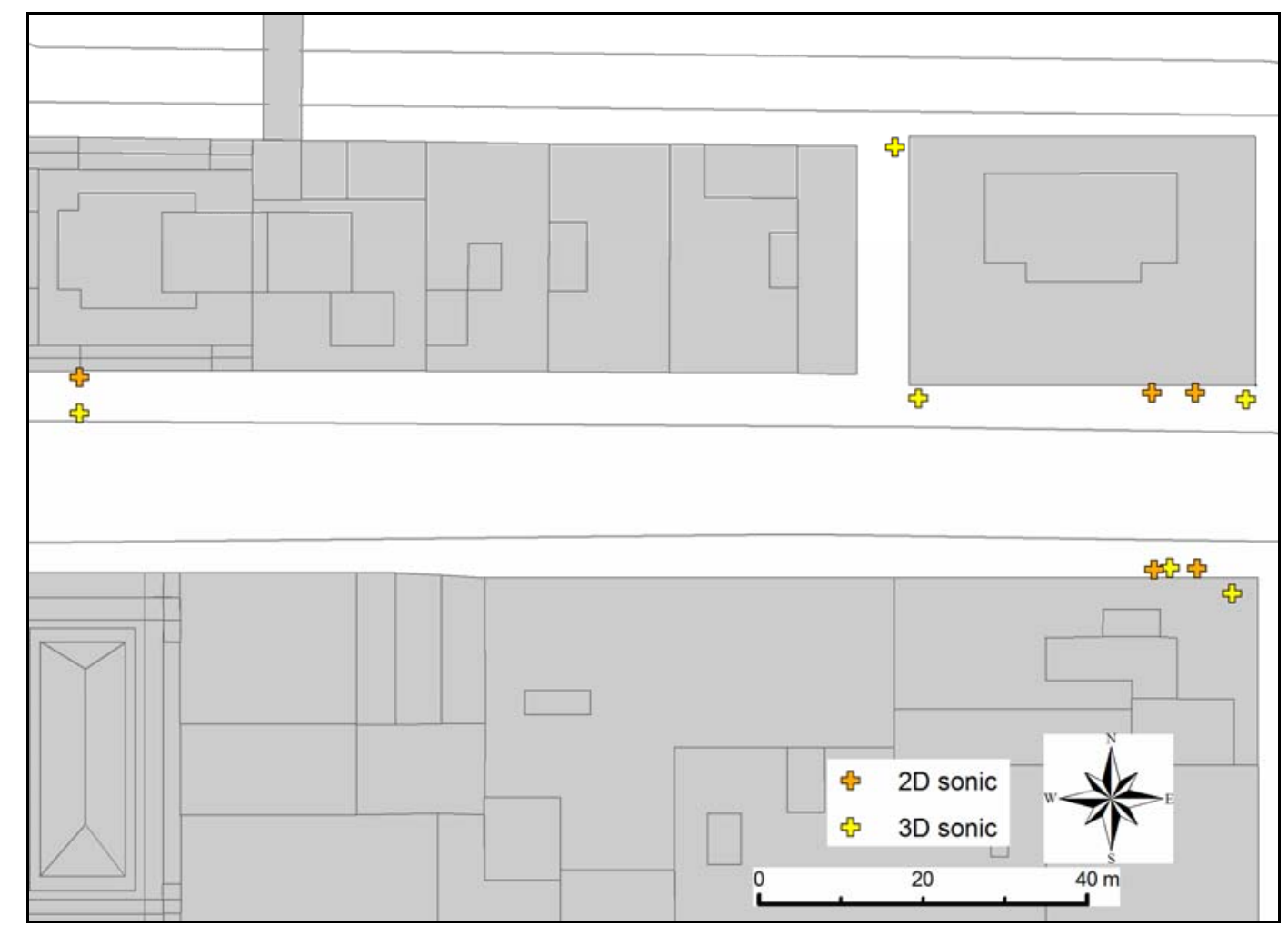

Figure A.26. LANL Sonic Anemometer Locations in Park Ave 


\section{A.11 Lawrence Livermore National Laboratory}

Lawrence Livermore National Laboratory deployed a number of tracer samplers, tracer analyzers and several 3D sonic anemometers. Forty-four tracer sampling instruments, called BlueBoxes (BB), were deployed at 22 unique outdoor locations during each of the IOPs 1 through 3 and 8 through 10 . The BlueBoxes were used in the indoor study during IOPs 4 through 7 . The outdoor coordinates for the BlueBoxes are presented in Table A.16, and the locations are shown in Figure A.27. LLNL deployed ten Miran instantaneous tracer analyzers. The deployment of the Mirans for each IOP is presented in Table A.16 and Figure A.28.

The eight 3D sonic anemometers deployed by LLNL were mounted on a crane that was located about $1 \mathrm{~km}$ north of the downtown release locations. Data from this site was collected continuously through the month-long study. Table A.18 presents the coordinates of the anemometers, while Figure A.29 shows the location on a map.

Table A.16. LLNL Tracer Sampler Locations for Each IOP. Samplers were not deployed outside for IOPs 4-7. The numbering system presented here is arbitrary, as the LLNL datafiles had no BlueBox identifiers.

\begin{tabular}{|c|c|c|c|c|c|}
\hline Instrument & Location Description & Latitude & Longitude & Easting & Northing \\
\hline IOP01 BB-1 & Bank One btwn Park \& Main - [1m AGL] & 35.46806 & 97.51426 & 634805 & 3925965 \\
\hline IOP01 BB-2 & Century Center Parking - [1m AGL] & 35.46755 & 97.51529 & 634712 & 3925908 \\
\hline IOP01 BB-3 & Century Center Parking Top - [18m AGL] & 35.46755 & 97.51529 & 634712 & 3925907 \\
\hline IOP01 BB-4 & Convention Center 2nd Level - [6m AGL] & 35.46631 & 97.51514 & 634728 & 3925770 \\
\hline IOP01 BB-5 & Corporate Towers Roof - [54m AGL] & 35.46788 & 97.51661 & 634592 & 3925942 \\
\hline IOP01 BB-6 & Corporate Towers - [1m AGL] & 35.46788 & 97.51659 & 634594 & 3925942 \\
\hline IOP01 BB-7 & Convention Center - [1m AGL] & 35.46634 & 97.51514 & 634728 & 3925773 \\
\hline IOP01 BB-8 & Broadway and Main NE - [1m AGL] & 35.46789 & 97.51427 & 634804 & 3925947 \\
\hline IOP01 BB-9 & Broadway and Main SE - [1m AGL] & 35.46759 & 97.51438 & 634795 & 3925913 \\
\hline IOP01 BB-10 & Broadway and Main SW - [1m AGL] & 35.46756 & 97.51462 & 634773 & 3925909 \\
\hline IOP01 BB-11 & Park \& Broadway SW - [1m AGL] & 35.46860 & 97.51463 & 634770 & 3926025 \\
\hline IOP01 BB-12 & Robinson and Main SE - [1m AGL] & 35.46753 & 97.51613 & 634636 & 3925904 \\
\hline IOP01 BB-13 & Sheridan \& Broadway NW - [1m AGL] & 35.46656 & 97.51470 & 634767 & 3925799 \\
\hline IOP01 BB-14 & Main St. W of Broadway - [1m AGL] & 35.46768 & 97.51500 & 634738 & 3925922 \\
\hline IOP01 BB-15 & Main Street Parking - [1m AGL] & 35.46783 & 97.51509 & 634730 & 3925939 \\
\hline IOP01 BB-16 & Main Street Parking Top - [26m AGL] & 35.46784 & 97.51509 & 634730 & 3925940 \\
\hline IOP01 BB-17 & NW corner of Renaissance - [1m AGL] & 35.46715 & 97.51437 & 634796 & 3925864 \\
\hline IOP01 BB-18 & OKLand Bldg. - [1m AGL] & 35.46785 & 97.51620 & 634629 & 3925939 \\
\hline IOP01 BB-19 & OKLand Bldg. Roof - [18m AGL] & 35.46785 & 97.51620 & 634629 & 3925940 \\
\hline IOP01 BB-20 & Park \& Broadway Roof SW - [48m AGL] & 35.46860 & 97.51464 & 634769 & 3926025 \\
\hline IOP01 BB-21 & Westin Lobby - [1m AGL] & 35.46712 & 97.51473 & 634764 & 3925860 \\
\hline IOP01 BB-22 & Westin Roof - [14m AGL] & 35.46712 & 97.51474 & 634763 & 3925860 \\
\hline IOP02 & Same as IOP01 & & & & \\
\hline
\end{tabular}


Table A.16 (contd)

\begin{tabular}{|c|c|c|c|c|c|}
\hline Instrument & Location Description & Latitude & Longitude & Easting & Northing \\
\hline IOP03 BB-1 & Cox Convention Ctr Entrance - [1 m AGL] & 35.46634 & 97.51514 & 634728 & 3925773 \\
\hline IOP03 BB-2 & Cox Convention Center Roof - [6 m AGL] & 35.46633 & 7.51514 & 634728 & 3925772 \\
\hline IOP03 BB-3 & Sheridan \& Broadway NW - [1 m AGL] & 35.46656 & 97.51470 & 634767 & 3925799 \\
\hline IOP03 BB-4 & Westin Lobby ground - [1 m AGL] & 35.46712 & 97.51473 & 634764 & 3925860 \\
\hline IOP03 BB-5 & NW corner Cox Convention Ctr - [1m AGL] & 35.46635 & 97.51606 & 634644 & 3925773 \\
\hline IOP03 BB-6 & Corporate Towers ground - [1 m AGL] & 35.46788 & 97.51659 & 634594 & 3925942 \\
\hline IOP03 BB-7 & Corporate Towers roof - [54 m AGL] & 35.46788 & 97.51661 & 634592 & 3925942 \\
\hline IOP03 BB-8 & Colcord Building ground - [1 m AGL] & 35.46659 & 97.51659 & 634596 & 3925799 \\
\hline IOP03 BB-9 & Colcord Building roof - [40 m AGL] & 35.46660 & 97.51659 & 634596 & 3925800 \\
\hline IOP03 BB-10 & Broadway \& Main SW - [1 m AGL] & 35.46754 & 97.51460 & 634775 & 3925907 \\
\hline IOP03 BB-11 & Century Center West ground - [1 m AGL] & 35.46720 & 97.51612 & 634637 & 3925868 \\
\hline IOP03 BB-12 & Century Center West top - [18 m AGL] & 35.46720 & 97.51611 & 634638 & 3925868 \\
\hline IOP03 BB-13 & Century Center South ground - [1 m AGL] & 35.46670 & 97.51589 & 634659 & 3925812 \\
\hline IOP03 BB-14 & Century Center South top - [18 m AGL] & 35.46671 & 97.51589 & 634659 & 3925813 \\
\hline IOP03 BB-15 & Main Street Parking ground - [1 m AGL] & 35.46783 & 97.51509 & 634730 & 3925939 \\
\hline IOP03 BB-16 & Main Street Parking top - [26 m AGL] & 35.46784 & 97.51509 & 634730 & 3925940 \\
\hline IOP03 BB-17 & Robinson Plaza NE - [1 m AGL] & 35.46767 & 97.51657 & 634596 & 3925919 \\
\hline IOP03 BB-18 & Robinson Plaza NW - [1 m AGL] & 35.46762 & 97.51703 & 634554 & 3925913 \\
\hline IOP03 BB-19 & Robinson Plaza SW - [1 m AGL] & 35.46707 & 97.51711 & 634548 & 3925852 \\
\hline IOP03 BB-20 & Robinson Plaza SE - [1 m AGL] & 35.46712 & 97.51662 & 634592 & 3925858 \\
\hline IOP03 BB-21 & Okland Building Ground - [1 m AGL] & 35.46785 & 97.51620 & 634629 & 3925939 \\
\hline IOP03 BB-22 & Okland Building Roof - [18 m AGL] & 35.46785 & 97.51620 & 634629 & 3925940 \\
\hline IOP08 BB-1 & 101 Park Avenue S ground - [1 m AGL] & 35.46886 & 97.51506 & 634731 & 3926053 \\
\hline IOP08 BB-2 & 101 Park Avenue 3-S - [34 m AGL] & 35.46886 & 97.51506 & 634731 & 3926053 \\
\hline IOP08 BB-3 & 101 Park Avenue 4-S - [12 m AGL] & 35.46886 & 97.51506 & 634731 & 3926053 \\
\hline IOP08 BB-4 & 101 Park Avenue Roof-S - [47 m AGL] & 35.46886 & 97.51506 & 634731 & 3926053 \\
\hline IOP08 BB-5 & Bank One Building roof - [148 m AGL] & 35.46805 & 97.51416 & 634814 & 3925965 \\
\hline IOP08 BB-6 & Bank One Building ground - [1 m AGL] & 35.46806 & 97.51419 & 634811 & 3925965 \\
\hline IOP08 BB-7 & Broadway\&Main NE - [1 m AGL] & 35.46777 & 97.51427 & 634804 & 3925933 \\
\hline IOP08 BB-8 & Broadway\&Main NW - [1 m AGL] & 35.46780 & 97.51467 & 634768 & 3925936 \\
\hline IOP08 BB-9 & Broadway\&Main SE - [1 m AGL] & 35.46755 & 97.51435 & 634797 & 3925909 \\
\hline IOP08 BB-10 & Broadway\&Main SW - [1 m AGL] & 35.46756 & 97.51462 & 634773 & 3925909 \\
\hline IOP08 BB-11 & Main St median W of Broadway - [1m AGL] & 35.46768 & 97.51500 & 634738 & 3925922 \\
\hline IOP08 BB-12 & NW corner Renaissance - [1 m AGL] & 35.46715 & 97.51437 & 634796 & 3925864 \\
\hline IOP08 BB-13 & Corporate Towers ground - [1 m AGL] & 35.46788 & 97.51659 & 634594 & 3925942 \\
\hline IOP08 BB-14 & Corporate Towers roof - [54 m AGL] & 35.46788 & 97.51661 & 634592 & 3925942 \\
\hline IOP08 BB-15 & Okland Building ground - [1 m AGL] & 35.46785 & 97.51620 & 634629 & 3925939 \\
\hline IOP08 BB-16 & Okland Building roof - [18 m AGL] & 35.46785 & 97.51620 & 634629 & 3925940 \\
\hline IOP08 BB-17 & Century Ctr Parking N ground - [1 m AGL] & 35.46755 & 97.51529 & 634712 & 3925908 \\
\hline IOP08 BB-18 & Century Center Parking N top - [18 m AGL] & 35.46755 & 97.51529 & 634712 & 3925907 \\
\hline IOP08 BB-19 & Main Street Parking ground - [1 m AGL] & 35.46783 & 97.51509 & 634730 & 3925939 \\
\hline IOP08 BB-20 & Main Street Parking top - [26 m AGL] & 35.46784 & 97.51509 & 634730 & 3925940 \\
\hline IOP08 BB-21 & Westin Hotel ground - [1 m AGL] & 35.46712 & 97.51473 & 634764 & 3925860 \\
\hline IOP08 BB-22 & Westin Hotel roof - [14 m AGL] & 35.46712 & 97.51474 & 634763 & 3925860 \\
\hline
\end{tabular}


Table A.16 (contd)

\begin{tabular}{|c|c|c|c|c|c|}
\hline Instrument & Location Description & Latitude & Longitude & Easting & Northing \\
\hline IOP09 BB-1 & 101 Park South Ground - [1 m AGL] & 35.46886 & 97.51497 & 634739 & 3926053 \\
\hline IOP09 BB-2 & 101 Park 3-South Profile - [34 m AGL] & 35.46886 & 97.51497 & 634739 & 3926053 \\
\hline IOP09 BB-3 & 101 Park 4-South Profile - [11 m AGL] & 35.46886 & 97.51497 & 634739 & 3926053 \\
\hline IOP09 BB-4 & 101 Park South Roof - [47 m AGL] & 35.46886 & 97.51497 & 634739 & 3926053 \\
\hline IOP09 BB-5 & 101 Park West Ground - [1 m AGL] & 35.46903 & 97.51511 & 634726 & 3926072 \\
\hline IOP09 BB-6 & 101 Park 5-West Profile - [34 m AGL] & 35.46903 & 97.51511 & 634726 & 3926072 \\
\hline IOP09 BB-7 & 101 Park 6-West Profile - [11 m AGL] & 35.46903 & 97.51511 & 634726 & 3926072 \\
\hline IOP09 BB-8 & 101 Park West Roof - [47 m AGL] & 35.46903 & 97.51511 & 634726 & 3926072 \\
\hline IOP09 BB-9 & 101 Park North Ground - [1 m AGL] & 35.46915 & 97.51502 & 634734 & 3926085 \\
\hline IOP09 BB-10 & 101 Park 7-North Profile - [11 m AGL] & 35.46915 & 97.51502 & 634734 & 3926085 \\
\hline IOP09 BB-11 & 101 Park 8-North Profile - [34 m AGL] & 35.46915 & 97.51502 & 634734 & 3926085 \\
\hline IOP09 BB-12 & 101 Park North Roof - [47 m AGL] & 35.46915 & 97.51502 & 634734 & 3926085 \\
\hline IOP09 BB-13 & 101 Park East Ground - [1 m AGL] & 35.46903 & 97.51462 & 634770 & 3926072 \\
\hline IOP09 BB-14 & 101 Park 1-East Profile - [35 m AGL] & 35.46903 & 97.51462 & 634770 & 3926072 \\
\hline IOP09 BB-15 & 101 Park 2-East Profile - [12 m AGL] & 35.46903 & 97.51462 & 634770 & 3926072 \\
\hline IOP09 BB-16 & 101 Park East Roof - [47 m AGL] & 35.46903 & 97.51462 & 634770 & 3926072 \\
\hline IOP09 BB-17 & Robinson \& Park NE - [1 m AGL] & 35.46889 & 97.51609 & 634637 & 3926055 \\
\hline IOP09 BB-18 & Robinson \& Couch SE - [1 m AGL] & 35.46916 & 97.51614 & 634632 & 3926085 \\
\hline IOP09 BB-19 & Leadership Square - [1 m AGL] & 35.46933 & 97.51661 & 634589 & 3926103 \\
\hline IOP09 BB-20 & Robinson \& Kerr SE - [1 m AGL] & 35.46973 & 97.51621 & 634625 & 3926148 \\
\hline IOP09 BB-21 & 100 Park North Ground - [1 m AGL] & 35.46870 & 97.51496 & 634740 & 3926035 \\
\hline IOP09 BB-22 & 100 Park Roof - [48 m AGL] & 35.46860 & 97.51467 & 634767 & 3926025 \\
\hline IOP10 BB-1 & 101 Park South Ground - [1 m AGL] & 35.46886 & 97.51497 & 634739 & 3926053 \\
\hline IOP10 BB-2 & 101 Park 3-South Profile - [34 m AGL] & 35.46886 & 97.51497 & 634739 & 3926053 \\
\hline IOP10 BB-3 & 101 Park 4-South Profile - [11 m AGL] & 35.46886 & 97.51497 & 634739 & 3926053 \\
\hline IOP10 BB-4 & 101 Park South Roof - [47 m AGL] & 35.46886 & 97.51497 & 634739 & 3926053 \\
\hline IOP10 BB-5 & 101 Park West Ground - [1 m AGL] & 35.46903 & 97.51511 & 634726 & 3926072 \\
\hline IOP10 BB-6 & 101 Park 5-West Profile - [34 m AGL] & 35.46903 & 97.51511 & 634726 & 3926072 \\
\hline IOP10 BB-7 & 101 Park 6-West Profile - [11 m AGL] & 35.46903 & 97.51511 & 634726 & 3926072 \\
\hline IOP10 BB-8 & 101 Park West Roof - [47 m AGL] & 35.46903 & 97.51511 & 634726 & 3926072 \\
\hline IOP10 BB-9 & 101 Park North Ground - [1 m AGL] & 35.46915 & 97.51502 & 634734 & 3926085 \\
\hline IOP10 BB-10 & 101 Park 7-North Profile - [11 m AGL] & 35.46915 & 97.51502 & 634734 & 3926085 \\
\hline IOP10 BB-11 & 101 Park 8-North Profile - [34 m AGL] & 35.46915 & 97.51502 & 634734 & 3926085 \\
\hline IOP10 BB-12 & 101 Park North Roof - [47 m AGL] & 35.46915 & 97.51502 & 634734 & 3926085 \\
\hline IOP10 BB-13 & 101 Park East Ground - [1 m AGL] & 35.46903 & 97.51462 & 634770 & 3926072 \\
\hline IOP10 BB-14 & 101 Park 1-East Profile - [35 m AGL] & 35.46903 & 97.51462 & 634770 & 3926072 \\
\hline IOP10 BB-15 & 101 Park 2-East Profile - [12 m AGL] & 35.46903 & 97.51462 & 634770 & 3926072 \\
\hline IOP10 BB-16 & 101 Park East Roof - [47 m AGL] & 35.46903 & 97.51462 & 634770 & 3926072 \\
\hline IOP10 BB-17 & Robinson\&Park NE - [1 m AGL] & 35.46889 & 97.51609 & 634637 & 3926055 \\
\hline IOP10 BB-18 & Robinson\&Couch SE - [1 m AGL] & 35.46916 & 97.51614 & 634632 & 3926085 \\
\hline IOP10 BB-19 & Leadership Square - [1 m AGL] & 35.46933 & 97.51661 & 634589 & 3926103 \\
\hline IOP10 BB-20 & 101 Park Bldg Vent in Alley - [1 m AGL] & 35.46906 & 97.51511 & 634726 & 3926075 \\
\hline IOP10 BB-21 & 100 Park Ground North - [1 m AGL] & 35.46870 & 97.51496 & 634740 & 3926035 \\
\hline IOP10 BB-22 & 100 Park Roof - [48 m AGL] & 35.46860 & 97.51467 & 634767 & 3926025 \\
\hline
\end{tabular}



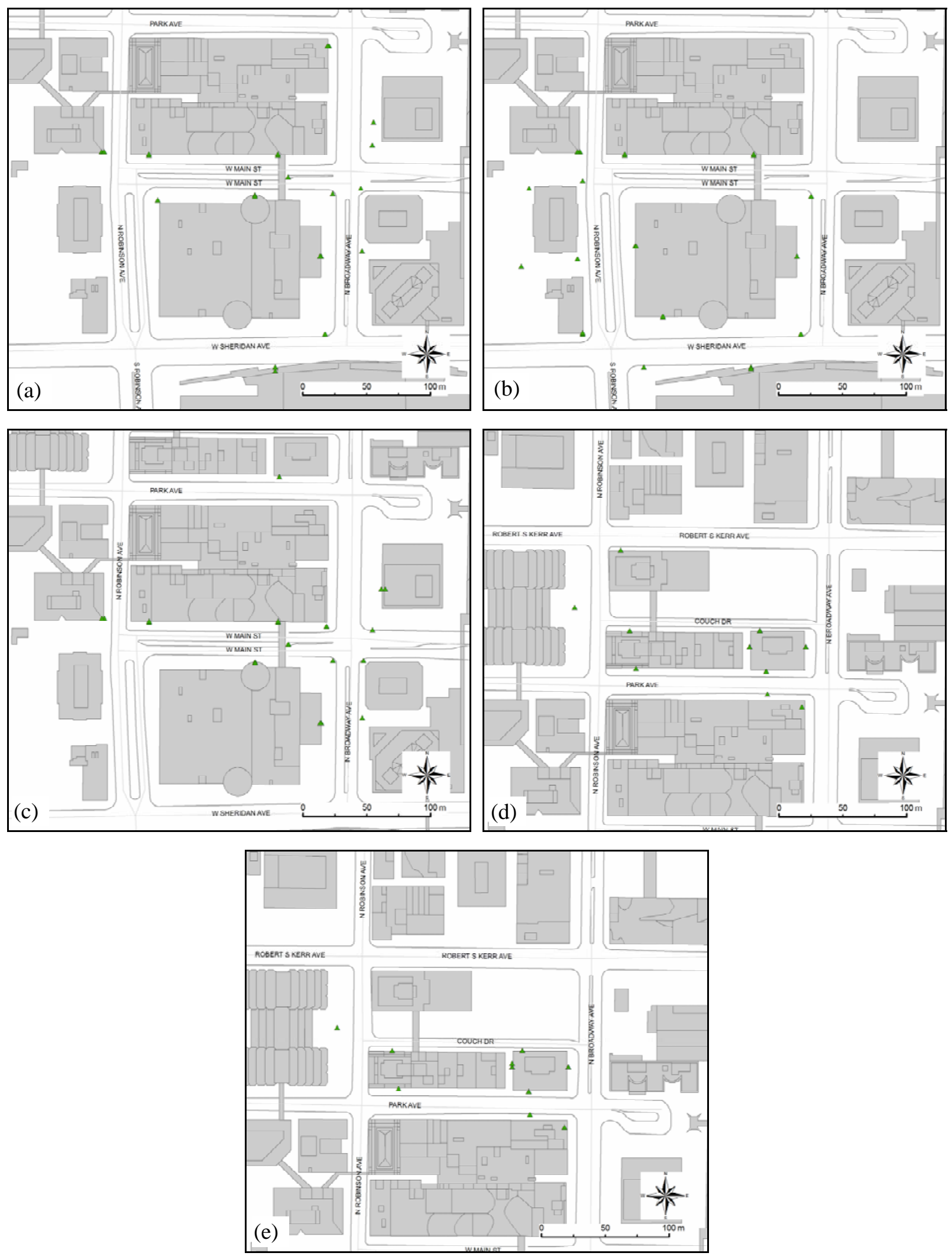

Figure A.27. LLNL BlueBox Locations During (a) IOP 1 and 2, (b) IOP 3, (c) IOP 8, (d) IOP 9, and (e) IOP 10 
Table A.17. LLNL Tracer Analyzer Locations

\begin{tabular}{|c|c|c|c|c|c|}
\hline Instrument & Location Description & Latitude & Longitude & Easting & Northing \\
\hline IOP01 - A & East of Broadway North of Main & 35.46783 & 97.51401 & 634828 & 3925940 \\
\hline IOP01 - B & East of Broadway South of Main & 35.46757 & 97.51410 & 634820 & 3925911 \\
\hline IOP01 - C & NE corner Main and Broadway & 35.46783 & 97.51437 & 634795 & 3925940 \\
\hline IOP01 - D & Broadway btwn Main and Park & 35.46820 & 97.51464 & 634770 & 3925980 \\
\hline IOP01 - E & NW corner Main and Broadway & 35.46776 & 97.51463 & 634772 & 3925932 \\
\hline IOP01 - F & N side of Main W of Broadway & 35.46782 & 97.51498 & 634740 & 3925938 \\
\hline IOP01 - G & S side of Main W of Broadway & 35.46755 & 97.51498 & 634740 & 3925908 \\
\hline IOP01 - H & SW corner Main and Broadway & 35.46756 & 97.51461 & 634774 & 3925910 \\
\hline IOP01 - I & Broadway btwn Main and Sheridan & 35.46713 & 97.51466 & 634770 & 3925862 \\
\hline IOP01 - J & Broadway btwn Main and Sheridan & 35.46707 & 97.51433 & 634800 & 3925855 \\
\hline IOP02 - A & East of Broadway North of Main & 35.46783 & 97.51401 & 634828 & 3925940 \\
\hline IOP02 - B & East of Broadway South of Main & 35.46757 & 97.51410 & 634820 & 3925911 \\
\hline IOP02 - C & NE corner Main and Broadway & 35.46783 & 97.51437 & 634795 & 3925940 \\
\hline IOP02 - D & Broadway btwn Main and Park & 35.46820 & 97.51464 & 634770 & 3925980 \\
\hline IOP02 - E & NW corner Main and Broadway & 35.46776 & 97.51463 & 634772 & 3925932 \\
\hline IOP02 - F & N side of Main W of Broadway & 35.46782 & 97.51498 & 634740 & 3925938 \\
\hline IOP02 - G & S side of Main W of Broadway & 35.46755 & 97.51498 & 634740 & 3925908 \\
\hline IOP02 - H & SW corner Main and Broadway & 35.46756 & 97.51461 & 634774 & 3925910 \\
\hline IOP02 - I & Broadway btwn Main and Sheridan & 35.46713 & 97.51466 & 634770 & 3925862 \\
\hline IOP02 - J & Broadway btwn Main and Sheridan & 35.46707 & 97.51433 & 634800 & 3925855 \\
\hline IOP03 - A & Sheridan SW corner of Colcord & 35.46658 & 97.51677 & 634579 & 3925798 \\
\hline IOP03 - B & NE corner Sheridan and Robinson & 35.46666 & 97.51619 & 634632 & 3925808 \\
\hline IOP03 - C & SE corner Sheridan and Robinson & 35.46636 & 97.51602 & 634648 & 3925774 \\
\hline IOP03 - D & Sheridan entrance to Visitor's Center & 35.46667 & 97.51560 & 634685 & 3925809 \\
\hline IOP03 - E & Main and Robinson on median & 35.46751 & 97.51637 & 634614 & 3925902 \\
\hline IOP03 - F & Robinson btwn Sheridan and Main & 35.46710 & 97.51660 & 634594 & 3925856 \\
\hline IOP03 - G & On Main E of Robinson & 35.46753 & 97.51597 & 634650 & 3925904 \\
\hline IOP03 - H & Robinson at Sheridan on median & 35.46664 & 97.51634 & 634618 & 3925805 \\
\hline IOP03 - I & West of Colcord building & 35.46672 & 97.51688 & 634569 & 3925813 \\
\hline IOP03 - J & NW corner Sheridan and Robinson & 35.46658 & 97.51652 & 634602 & 3925798 \\
\hline IOP04 - A & NE corner Sheridan and Robinson & 35.46666 & 97.51619 & 634632 & 3925808 \\
\hline IOP04 - B & NE corner Sheridan and Robinson & 35.46666 & 97.51619 & 634632 & 3925808 \\
\hline IOP04 - C & SE corner Sheridan and Robinson & 35.46636 & 97.51602 & 634648 & 3925774 \\
\hline IOP04 - D & Sheridan entrance to Visitor's Center & 35.46667 & 97.51560 & 634685 & 3925809 \\
\hline IOP04 - E & NW corner Sheridan and Robinson & 35.46658 & 97.51652 & 634602 & 3925798 \\
\hline IOP04 - F & On Main E of Robinson & 35.46753 & 97.51597 & 634650 & 3925904 \\
\hline IOP04 - G & Robinson at Sheridan on median & 35.46664 & 97.51634 & 634618 & 3925805 \\
\hline IOP04 - H & Main and Robinson on median & 35.46751 & 97.51637 & 634614 & 3925902 \\
\hline IOP04 - I & Sheridan SW corner of Colcord & 35.46658 & 97.51677 & 634579 & 3925798 \\
\hline IOP04 - J & Robinson btwn Sheridan and Main & 35.46710 & 97.51660 & 634594 & 3925856 \\
\hline IOP05 - A & NE corner Sheridan and Robinson & 35.46666 & 97.51619 & 634632 & 3925808 \\
\hline IOP05 - B & Robinson at Sheridan on median & 35.46664 & 97.51634 & 634618 & 3925805 \\
\hline IOP05 - C & Sheridan SW corner of Colcord & 35.46658 & 97.51677 & 634579 & 3925798 \\
\hline IOP05 - D & NW corner Sheridan and Robinson & 35.46658 & 97.51652 & 634602 & 3925798 \\
\hline IOP05 - E & Sheridan entrance to Visitor's Center & 35.46667 & 97.51560 & 634685 & 3925809 \\
\hline IOP05 - F & On Main E of Robinson & 35.46753 & 97.51597 & 634650 & 3925904 \\
\hline
\end{tabular}


Table A.17. (contd)

\begin{tabular}{|c|c|c|c|c|c|}
\hline Instrument & Location Description & Latitude & Longitude & Easting & Northing \\
\hline IOP05 - G & SE corner Sheridan and Robinson & 35.46636 & 97.51602 & 634648 & 3925774 \\
\hline IOP05 - H & Main and Robinson on median & 35.46751 & 97.51637 & 634614 & 3925902 \\
\hline IOP05 - I & West of Colcord building & 35.46672 & 97.51688 & 634569 & 3925813 \\
\hline IOP05 - J & Robinson btwn Sheridan and Main & 35.46710 & 97.51660 & 634594 & 3925856 \\
\hline IOP06 - A & West of Colcord building & 35.46672 & 97.51688 & 634569 & 3925813 \\
\hline IOP06 - B & Robinson at Sheridan on median & 35.46664 & 97.51634 & 634618 & 3925805 \\
\hline IOP06 - C & Sheridan entrance to Visitor's Center & 35.46667 & 97.51560 & 634685 & 3925809 \\
\hline IOP06 - D & NE corner Sheridan and Robinson & 35.46666 & 97.51619 & 634632 & 3925808 \\
\hline IOP06 - E & SE corner Sheridan and Robinson & 35.46636 & 97.51602 & 634648 & 3925774 \\
\hline IOP06 - F & On Main E of Robinson & 35.46753 & 97.51597 & 634650 & 3925904 \\
\hline IOP06 - G & Sheridan SW corner of Colcord & 35.46658 & 97.51677 & 634579 & 3925798 \\
\hline IOP06 - H & NW corner Sheridan and Robinson & 35.46658 & 97.51652 & 634602 & 3925798 \\
\hline IOP06 - I & Robinson btwn Sheridan and Main & 35.46710 & 97.51660 & 634594 & 3925856 \\
\hline IOP06 - J & Main and Robinson on median & 35.46751 & 97.51637 & 634614 & 3925902 \\
\hline IOP07 - A & West of Colcord building & 35.46672 & 97.51688 & 634569 & 3925813 \\
\hline IOP07 - B & SE corner Sheridan and Robinson & 35.46636 & 97.51602 & 634648 & 3925774 \\
\hline IOP07 - C & Sheridan entrance to Visitor's Center & 35.46667 & 97.51560 & 634685 & 3925809 \\
\hline IOP07 - D & Robinson at Sheridan on median & 35.46664 & 97.51634 & 634618 & 3925805 \\
\hline IOP07 - E & NE corner Sheridan and Robinson & 35.46666 & 97.51619 & 634632 & 3925808 \\
\hline IOP07 - F & Sheridan SW corner of Colcord & 35.46658 & 97.51677 & 634579 & 3925798 \\
\hline IOP07 - G & Robinson btwn Sheridan and Main & 35.46710 & 97.51660 & 634594 & 3925856 \\
\hline IOP07 - H & NW corner Sheridan and Robinson & 35.46658 & 97.51652 & 634602 & 3925798 \\
\hline IOP07 - I & On Main E of Robinson & 35.46753 & 97.51597 & 634650 & 3925904 \\
\hline IOP07 - J & Main and Robinson on median & 35.46751 & 97.51637 & 634614 & 3925902 \\
\hline IOP08 - A & East of Broadway North of Main & 35.46783 & 97.51401 & 634828 & 3925940 \\
\hline IOP08 - B & East of Broadway South of Main & 35.46757 & 97.51410 & 634820 & 3925911 \\
\hline IOP08 - C & NE corner Main and Broadway & 35.46783 & 97.51437 & 634795 & 3925940 \\
\hline IOP08 - D & Broadway btwn Main and Park & 35.46820 & 97.51464 & 634770 & 3925980 \\
\hline IOP08 - E & NW corner Main and Broadway & 35.46776 & 97.51463 & 634772 & 3925932 \\
\hline IOP08 - F & N side of Main W of Broadway & 35.46782 & 97.51498 & 634740 & 3925938 \\
\hline IOP08 - G & S side of Main W of Broadway & 35.46755 & 97.51498 & 634740 & 3925908 \\
\hline IOP08 - H & SW corner Main and Broadway & 35.46756 & 97.51461 & 634774 & 3925910 \\
\hline IOP08 - I & Broadway btwn Main and Sheridan & 35.46713 & 97.51466 & 634770 & 3925862 \\
\hline IOP08 - J & Broadway btwn Main and Sheridan & 35.46707 & 97.51433 & 634800 & 3925855 \\
\hline IOP09 - A & SW corner Park and Broadway & 35.46868 & 97.51461 & 634772 & 3926034 \\
\hline IOP09 - B & Couch Street just E of Robinson & 35.46924 & 97.51545 & 634695 & 3926095 \\
\hline IOP09 - C & Broadway E of Couch Street & 35.46927 & 97.51432 & 634797 & 3926100 \\
\hline IOP09 - D & Couch Street in Kerr Park & 35.46924 & 97.51514 & 634723 & 3926095 \\
\hline IOP09 - E & Park Avenue S of City Place & 35.46884 & 97.51566 & 634676 & 3926050 \\
\hline IOP09 - F & Park Avenue median E of Broadway & 35.46871 & 97.51419 & 634810 & 3926038 \\
\hline IOP09 - G & Robinson just S of Park & 35.46857 & 97.51638 & 634611 & 3926019 \\
\hline IOP09 - H & Park Avenue just E of Robinson & 35.46870 & 97.51561 & 634681 & 3926035 \\
\hline IOP09 - I & NW corner Park and Broadway & 35.46882 & 97.62617 & 634768 & 3926048 \\
\hline IOP09 - J & NW corner Couch and Broadway & 35.46916 & 97.51481 & 634753 & 3926087 \\
\hline
\end{tabular}


Table A.17. (contd)

\begin{tabular}{|l|l|c|c|c|c||}
\hline Instrument & Location Description & Latitude & Longitude & Easting & Northing \\
\hline \hline IOP10 - A & Couch Street just E of Robinson & 35.46924 & 97.51545 & 634695 & 3926095 \\
\hline IOP10 - B & Park Avenue S of City Place & 35.46884 & 97.51566 & 634676 & 3926050 \\
IOP10 - C & Park Avenue just E of Robinson & 35.46870 & 97.51561 & 634681 & 3926035 \\
\hline IOP10 - D & Broadway E of Couch Street & 35.46927 & 97.51432 & 634797 & 3926100 \\
\hline IOP10 - E & NW corner Park and Broadway & 35.46882 & 97.51465 & 634768 & 3926049 \\
IOP10 - F & NW corner Couch and Broadway & 35.46916 & 97.51481 & 634753 & 3926087 \\
\hline IOP10 - G & Not used & & & & \\
\hline IOP10 - H & SW corner Park and Broadway & 35.46868 & 97.51461 & 634772 & 3926034 \\
\hline IOP10 - I & Not used & & & & \\
\hline IOP10 - J & Couch Street in Kerr Park & 35.46924 & 97.51514 & 634723 & 3926095 \\
\hline
\end{tabular}
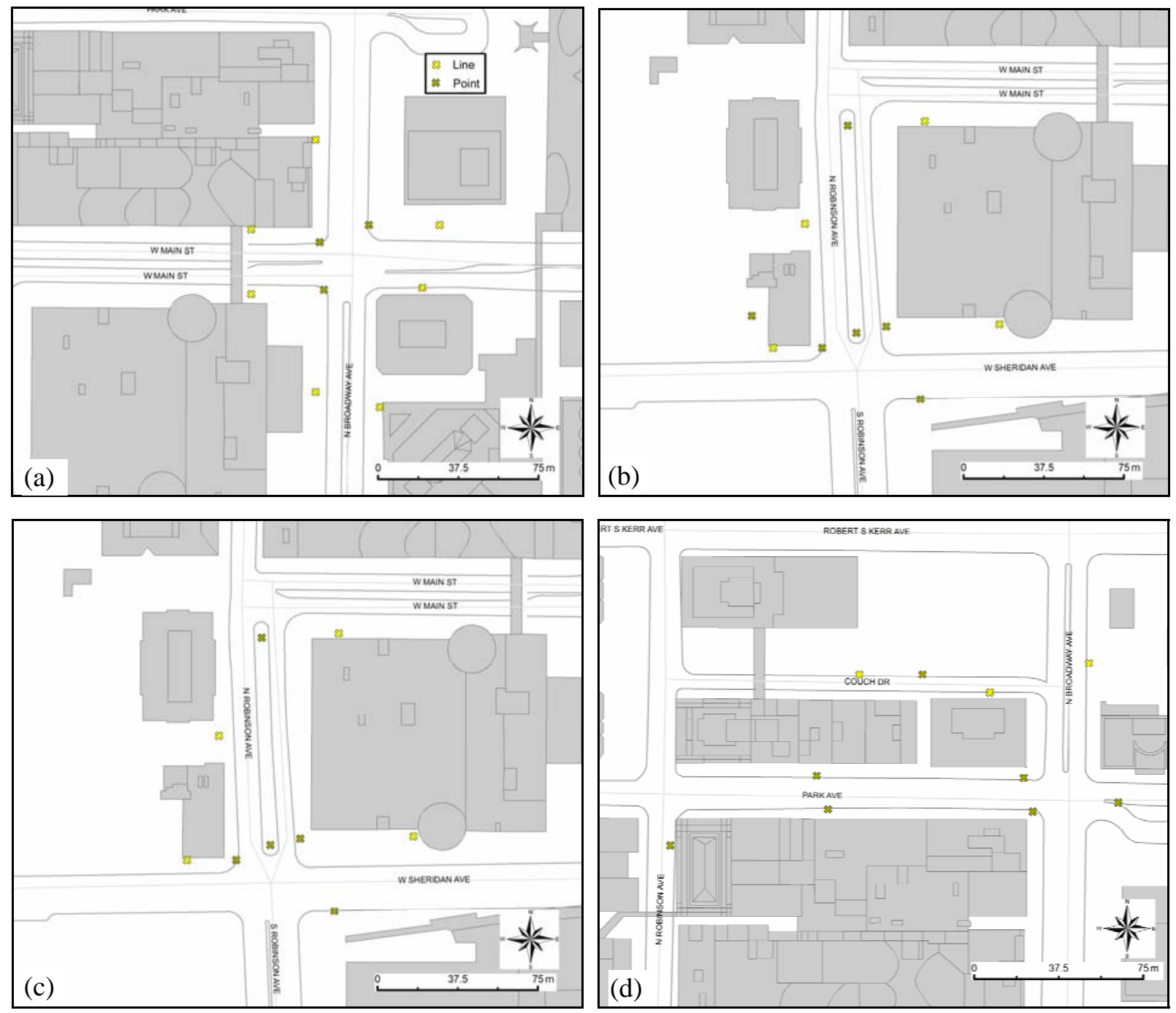

Figure A.28. LLNL Miran Locations During (a) IOP 1, 2, and 8, (b) IOP 3, 5, 6, and 7, (c) IOP 4, (d) IOP 9, and (e) IOP 10 


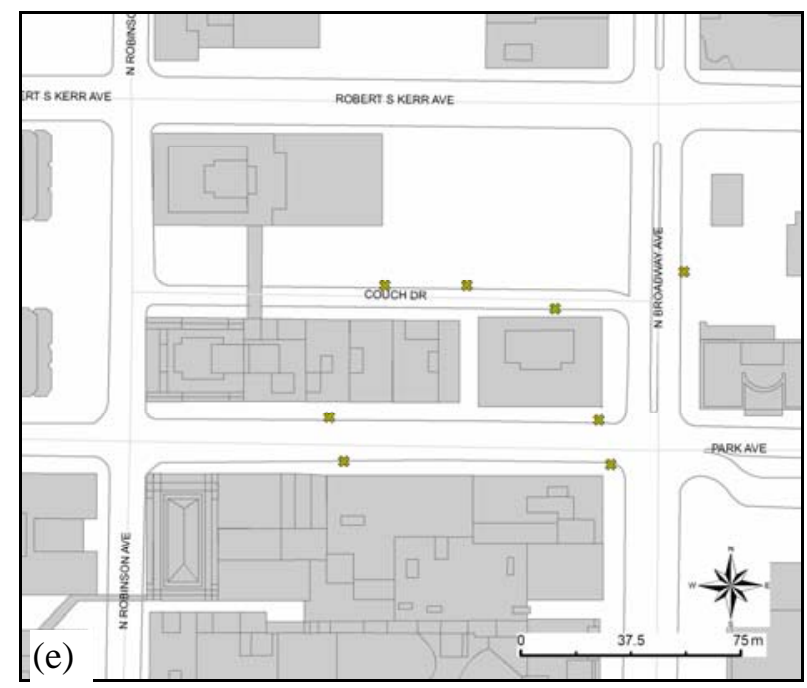

Figure A.28. (Contd)

Table A.18. LLNL Sonic Anemometer Location

\begin{tabular}{|l|l|c|c|c|c|}
\hline Instrument & Location Description & Latitude & Longitude & Easting & Northing \\
\hline \hline Sonic A - 7.8m agl & SW corner of 8th \& Harvey & 35.475718 & 97.51784 & 634467 & 3926810 \\
\hline Sonic B - 14.6m agl & SW corner of 8th \& Harvey & 35.475718 & 97.51784 & 634467 & 3926810 \\
\hline Sonic C - 21.5m agl & SW corner of 8th \& Harvey & 35.475718 & 97.51784 & 634467 & 3926810 \\
\hline Sonic D - 28.3m agl & SW corner of 8th \& Harvey & 35.475718 & 97.51784 & 634467 & 3926810 \\
\hline Sonic E - 42.5m agl & SW corner of 8th \& Harvey & 35.475718 & 97.51784 & 634467 & 3926810 \\
\hline Sonic F - 55.8m agl & SW corner of 8th \& Harvey & 35.475718 & 97.51784 & 634467 & 3926810 \\
\hline Sonic G - 69.7m agl & SW corner of 8th \& Harvey & 35.475718 & 97.51784 & 634467 & 3926810 \\
\hline Sonic H - 83.2m agl & SW corner of 8th \& Harvey & 35.475718 & 97.51784 & 634467 & 3926810 \\
\hline
\end{tabular}

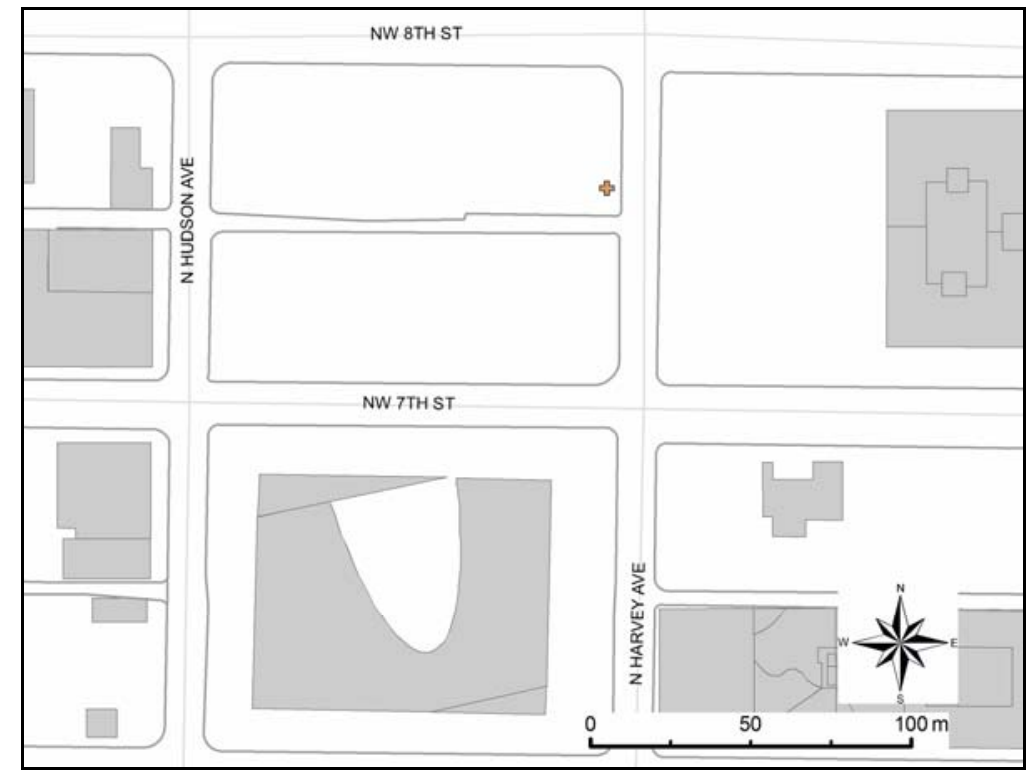

Figure A.29. LLNL Sonic Anemometer Location 


\section{A.12 Oklahoma Climatological Survey}

The Oklahoma Climatological Survey was responsible for collecting data from the permanent meteorological stations of the Oklahoma Mesonet, National Weather Service (NWS) automated surface observing system (ASOS) sites, profiler/RASS, and weather radar sites. Coordinates for the meteorological measurement sites are presented in Table A.19, while the locations are shown in Figures A.30 and A.31.

Table A.19. OCS Meteorological Measurement Locations (Note: KINX Tulsa is in UTM Zone 15)

\begin{tabular}{|l|l|c|c|c|c||}
\hline \hline Instrument & Location Description & Latitude & Longitude & Easting & Northing \\
\hline \hline Mesonet - ELRE & 5miles WNW of El Reno & 35.54848 & 98.03655 & 587327 & 3934297 \\
\hline Mesonet - GUTH & 4 miles WSW of Guthrie & 35.84892 & 97.47979 & 637279 & 3968258 \\
Mesonet - KING & 2 miles NE of Kingfisher & 35.88052 & 97.91123 & 598278 & 3971244 \\
Mesonet - MINC & 2 miles SSW of Minco & 35.27224 & 97.95557 & 594991 & 3903734 \\
\hline Meosnet - NRMN & 2.1 miles NW of Norman & 35.23612 & 97.46489 & 639683 & 3900308 \\
\hline Meosnet - SPEN & 2 miles ENE of Spencer & 35.54207 & 97.34142 & 650350 & 3934424 \\
\hline NWS - KOUN & Max Westhiemer Field & 35.24694 & 97.47250 & 638972 & 3901498 \\
\hline NWS - KPWA & Wiley Post Airport & 35.53590 & 97.64749 & 622612 & 3933316 \\
\hline NWS - KOKC & Will Rogers Airport & 35.38861 & 97.60028 & 627124 & 3917039 \\
\hline NWS - KTLX & Twin Lakes Radar (OKC) & 35.33310 & 97.27780 & 656522 & 3911344 \\
\hline Radar - KVNX & Vance AFB Radar & 36.74080 & 98.12780 & 577868 & 4066474 \\
\hline Radar - KFDR & Frederick Radar & 34.36220 & 98.97640 & 502170 & 3802317 \\
\hline Radar - KINX & Tulsa & 36.17500 & 101.56470 & 269338 & 4006407 \\
\hline Profiler/RASS & Norman, OK & 35.23505 & 97.46442 & 639728 & 3900190 \\
\hline \hline
\end{tabular}




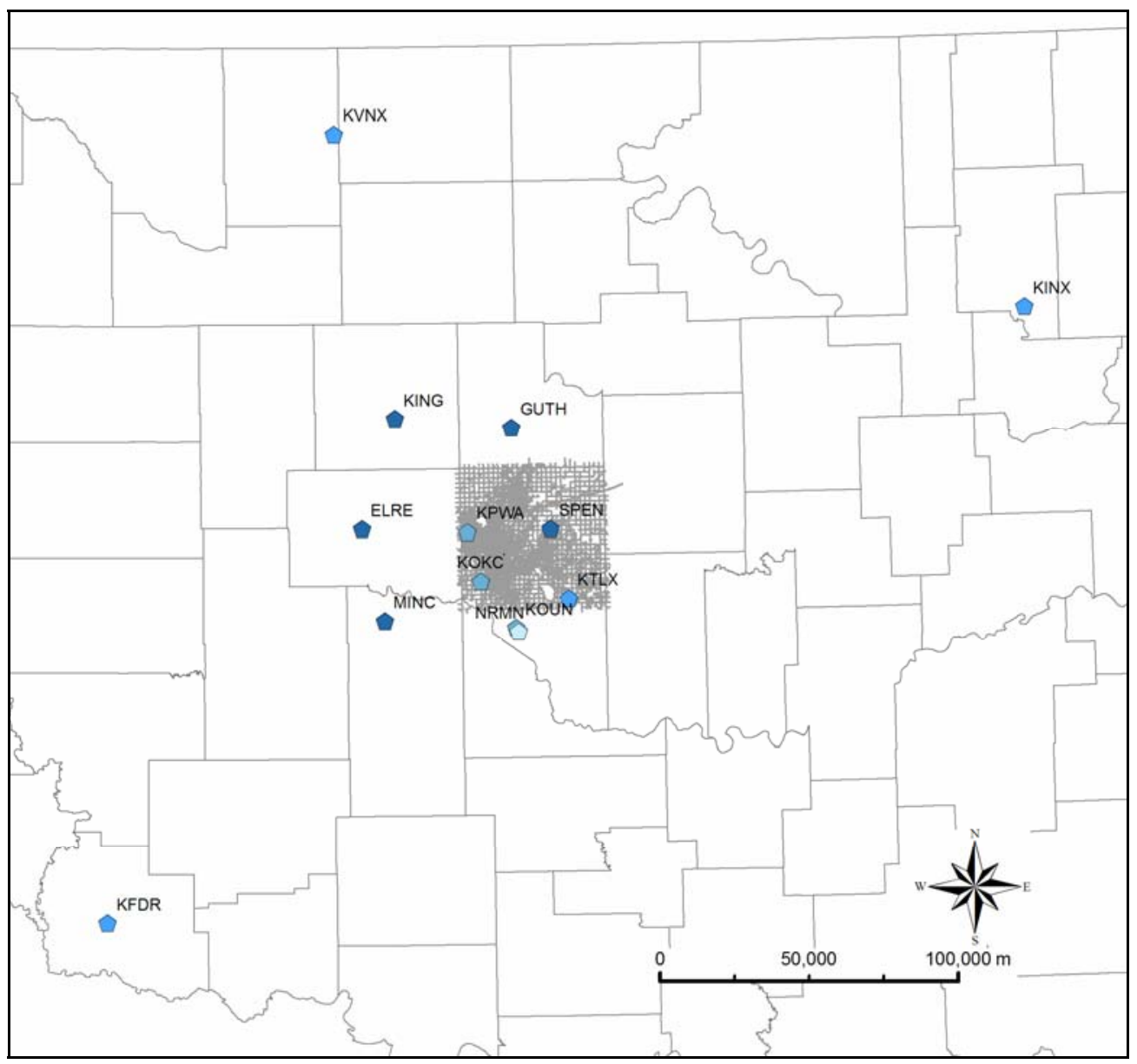

Figure A.30. Overview of OCS Meteorological Measurement Locations. Light grey outlines represent county borders. Oklahoma City is in the center of this image.
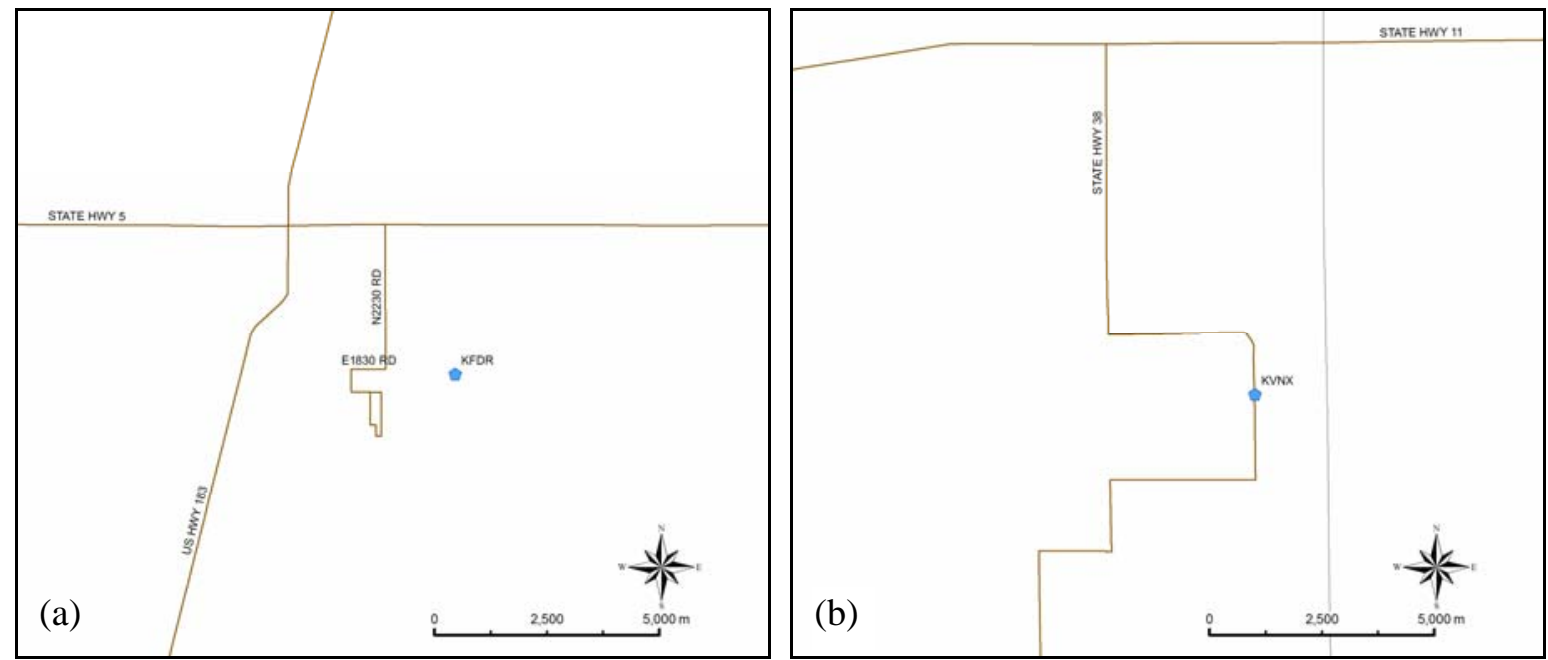

Figure A.31. OCS Meteorological Measurement Locations (a) KFDR, (b) KVNS, (c) KING, (d) ELRE, (e) MINC, (f) GUTH, (g) KPWA, (h) KOKC, (i) NRMN and KOUN, (j) SPEN, (k) KTLX, and (l) KINX 

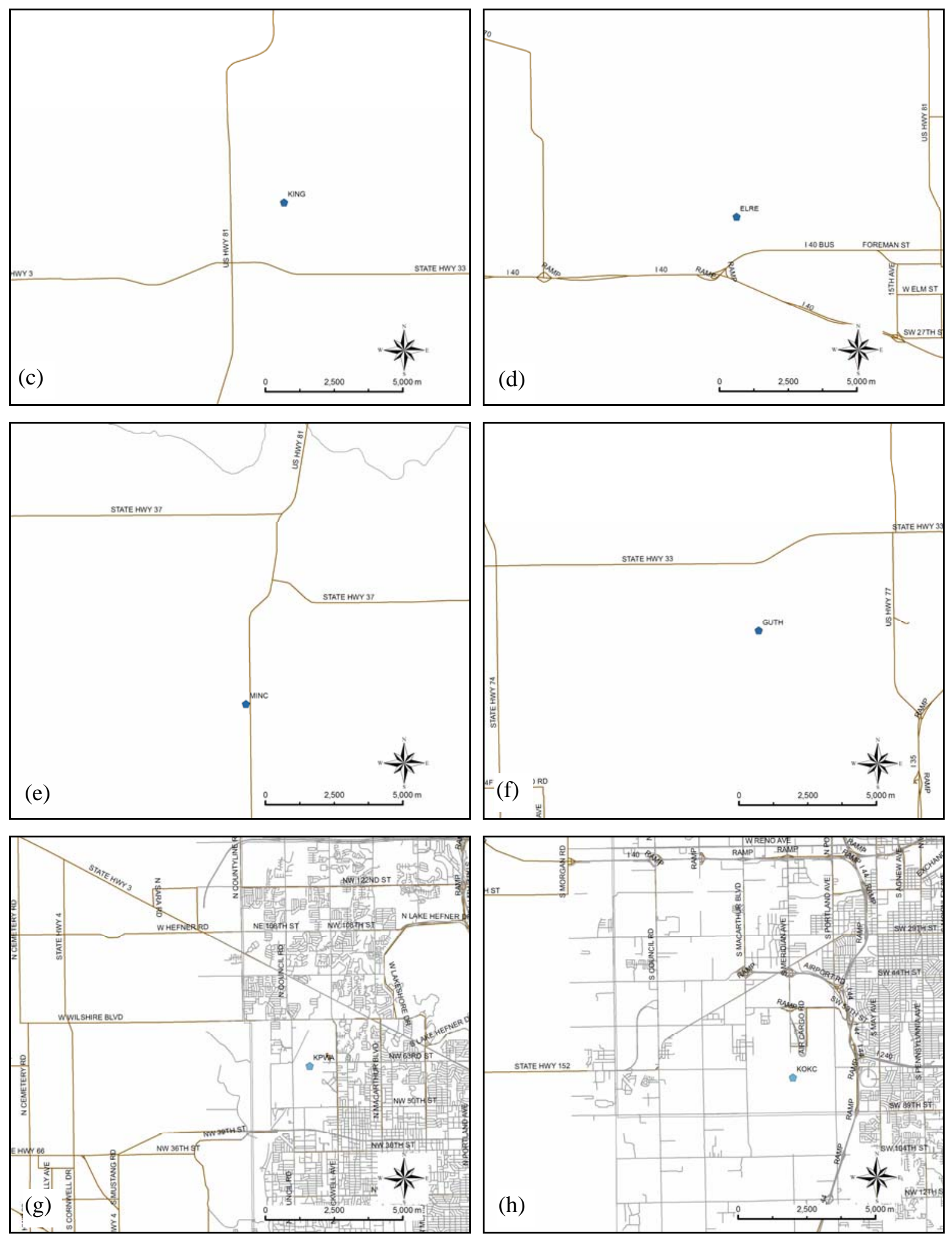

Figure A.31. (Contd) 

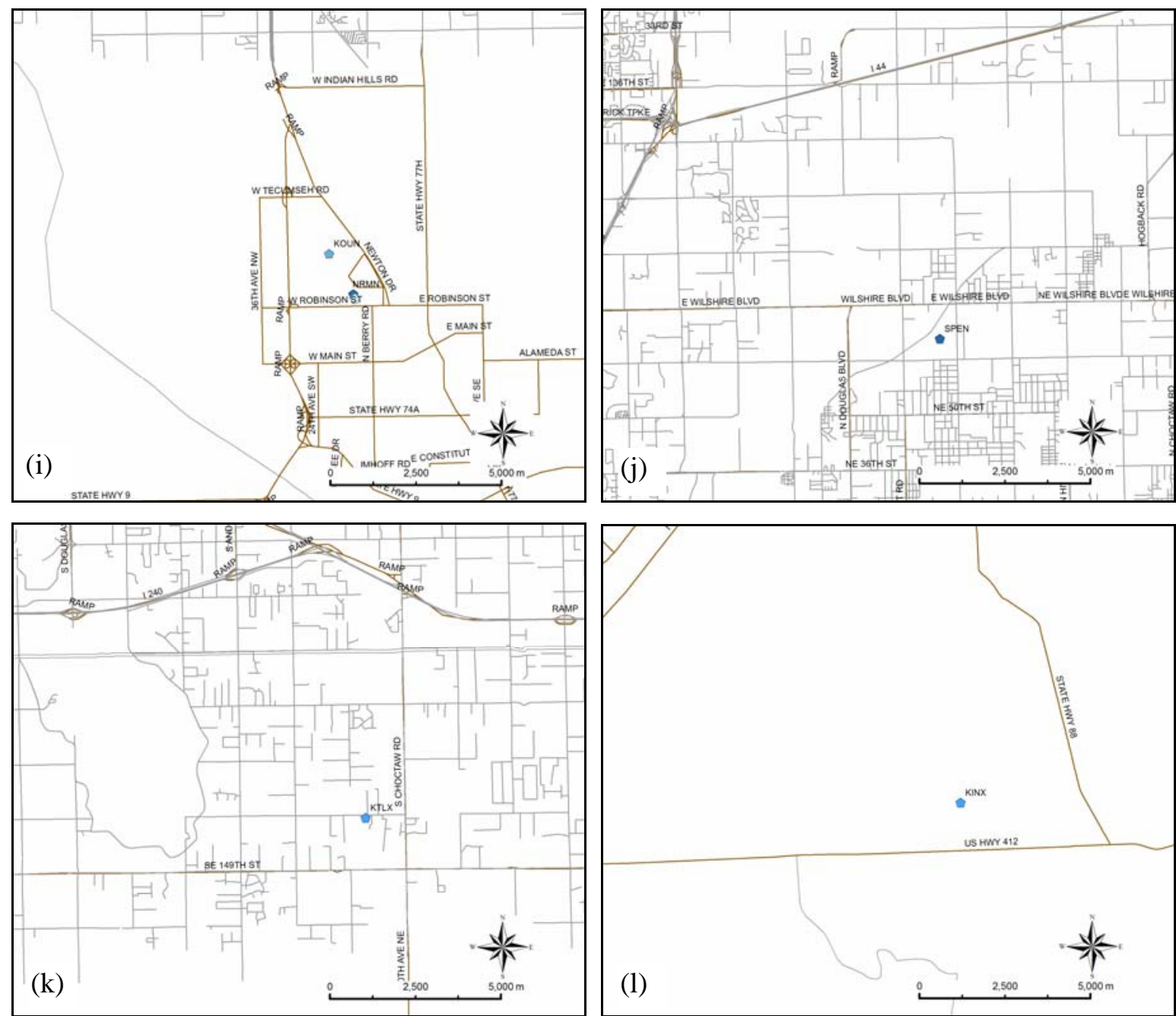

Figure A.31. (Contd)

\section{A.13 University of Oklahoma}

The University of Oklahoma instrumented two towers in the center of the Park Avenue street canyon with 5 3D sonic anemometers on each tower. These anemometers collected data continuously throughout the month-long field study. The coordinates of these towers are presented in Table A.20, while the locations are shown in Figure A.32. OU also took a number of photographs documenting the urban landscape of Oklahoma City. These photos can be found on the following website: http://weather.ou.edu/ pkklein/OKCphotos/OKCbuildmain.htm

Table A.20. OU Tower Locations

\begin{tabular}{|l|l|c|l|c|c|}
\hline Instrument & Location Description & Latitude & Longitude & Easting & Northing \\
\hline \hline Tower 1 (5 sonics) & North side of Park Ave & 35.468815 & 97.515616 & 634680.4 & 3926047.3 \\
\hline Tower 2 (5 sonics) & South side of Park Ave & 35.468736 & 97.515563 & 634685.3 & 3926038.7 \\
\hline
\end{tabular}




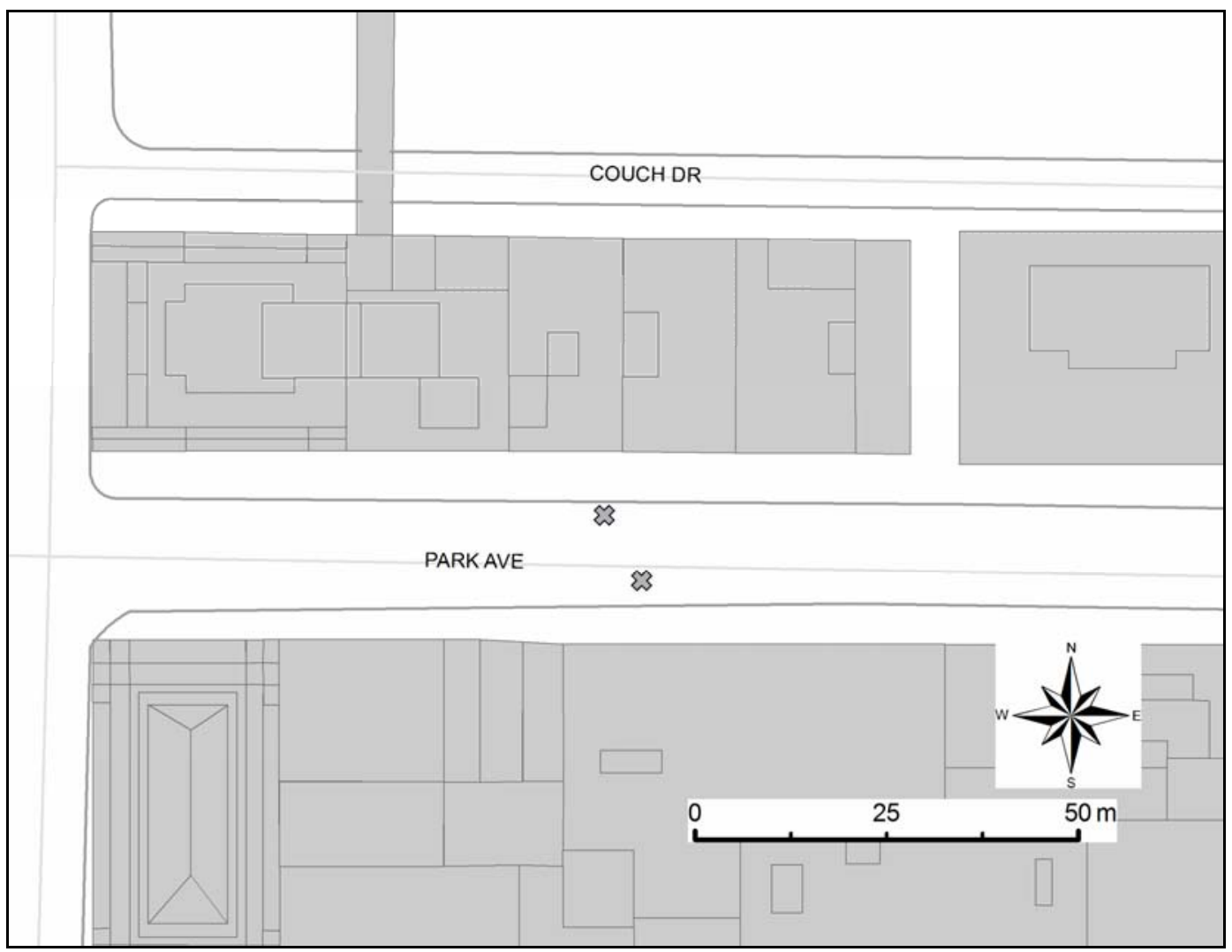

Figure A.32. OU Sonic Tower Locations

\section{A.14 Pacific Northwest National Laboratory}

The Pacific Northwest National Laboratory deployed five meteorological stations, several profile instruments, and 33 HOBO temperature sensors throughout Oklahoma City. The coordinates of the instruments are presented in Table A.21, and locations are shown in Figures A.33 through A.35. 
Table A.21. PNNL Meteorological Station, Profile, and HOBO Locations

\begin{tabular}{|c|c|c|c|c|c|}
\hline Instrument & Location Description & Latitude & Longitude & Easting & Northing \\
\hline Met station 01 & $\begin{array}{l}\text { N 10th \& Dewey - St Anthony's Hospital [45m } \\
\text { agl] }\end{array}$ & 35.47786 & 97.52346 & 633954 & 3927040 \\
\hline Met station 02 & $\begin{array}{l}\text { Park btwn Harvey \& Robinson - OK Tower } \\
\text { [153m agl] }\end{array}$ & 35.46848 & 97.51705 & 634551 & 3926008 \\
\hline Met station 03 & Colcord \& Lee - Civic Ctr Music Hall [37m agl] & 35.46889 & 97.52380 & 633938 & 3926045 \\
\hline Met station 04 & $\begin{array}{l}\text { N 10th btwn Harvey \& Robinson - Ed Minor's } \\
\text { Bldg [15m agl] }\end{array}$ & 35.47835 & 97.51688 & 634550 & 3927103 \\
\hline Met station 05 & Robinson btwn N 6th \& 7th - OK DEQ [49m agl] & 35.47426 & 97.51650 & 634591 & 3926650 \\
\hline $\begin{array}{l}\text { sodar, rawindsonde, } \\
\& \text { profiler/RASS }\end{array}$ & $\begin{array}{l}1400 \text { S Shartel Ave - along fence } \mathrm{N} \text { of the OKC } \\
\text { traffic maintenance }\end{array}$ & 35.45295 & 97.52534 & 633824 & 3924274 \\
\hline HOBO T01 & Main \& Ellison & 35.46785 & 97.53377 & 633035 & 3925916 \\
\hline HOBO T02 & Main \& Clegern & 35.46781 & 97.53125 & 633263 & 3925915 \\
\hline HOBO T03 & Main \& Classen & 35.46788 & 97.52898 & 633469 & 3925925 \\
\hline HOBO T04 & Main \& Shartel & 35.46791 & 97.52592 & 633747 & 3925933 \\
\hline HOBO T05 & Main \& Dewey & 35.46796 & 97.52271 & 634038 & 3925943 \\
\hline HOBO T06 & Main \& Walker & 35.46793 & 97.52147 & 634151 & 3925941 \\
\hline HOBO T07 & Main \& Hudson & 35.46789 & 97.51968 & 634313 & 3925939 \\
\hline HOBO T08 & Main \& Harvey & 35.46771 & 97.51792 & 634473 & 3925922 \\
\hline HOBO T09 & Main \& Robinson & 35.46775 & 97.51654 & 634598 & 3925928 \\
\hline HOBO T10 & Main \& Broadway & 35.46780 & 97.51436 & 634796 & 3925937 \\
\hline HOBO T11 & Main \& Gaylord & 35.46775 & 97.51295 & 634924 & 3925933 \\
\hline HOBO T12 & Main \& Oklahoma & 35.46769 & 97.51073 & 635126 & 3925929 \\
\hline HOBO T13 & Main \& Mickey Mantle & 35.46760 & 97.50863 & 635316 & 3925922 \\
\hline HOBO T14 & Main \& Joe Carter & 35.46688 & 97.50609 & 635548 & 3925846 \\
\hline HOBO T15 & Sheridan \& Byers & 35.46634 & 97.50380 & 635757 & 3925789 \\
\hline HOBO T16 & Tracks \& Lindsay & 35.46810 & 97.50067 & 636038 & 3925989 \\
\hline HOBO T17 & Tracks \& Kelley & 35.46815 & 97.49593 & 636468 & 3926001 \\
\hline HOBO T18 & Robinson \& S 11th & 35.45388 & 97.51608 & 634663 & 3924390 \\
\hline HOBO T19 & Robinson \& S 9th & 35.45581 & 97.51612 & 634656 & 3924604 \\
\hline HOBO T20 & Robinson \& S 6th & 35.45915 & 97.51637 & 634628 & 3924974 \\
\hline HOBO T21 & Robinson \& S 4th & 35.46117 & 97.51636 & 634626 & 3925198 \\
\hline HOBO T22 & Robinson \& S 2nd & 35.46303 & 97.51637 & 634622 & 3925405 \\
\hline HOBO T23 & Robinson \& Reno & 35.46415 & 97.51659 & 634600 & 3925529 \\
\hline HOBO T24 & Robinson btwn Reno and Sheridan & 35.46544 & 97.51648 & 634608 & 3925672 \\
\hline HOBO T25 & Robinson \& Sheridan & 35.46635 & 97.51658 & 634597 & 3925773 \\
\hline HOBO T26 & Robinson \& Park & 35.46868 & 97.51649 & 634601 & 3926031 \\
\hline HOBO T27 & Robinson \& Kerr & 35.46973 & 97.51647 & 634601 & 3926148 \\
\hline HOBO T28 & Robinson \& McGee & 35.47078 & 97.51644 & 634602 & 3926264 \\
\hline HOBO T29 & Robinson \& N 4th & 35.47181 & 97.51640 & 634604 & 3926378 \\
\hline HOBO T30 & Robinson \& N 6th & 35.47392 & 97.51636 & 634604 & 3926612 \\
\hline HOBO T31 & Robinson \& N 8th & 35.47582 & 97.51604 & 634630 & 3926824 \\
\hline HOBO T32 & Robinson \& N 10th & 35.47813 & 97.51617 & 634615 & 3927080 \\
\hline HOBO T33 & Robinson \& N 11th & 35.48010 & 97.51593 & 634633 & 3927299 \\
\hline
\end{tabular}




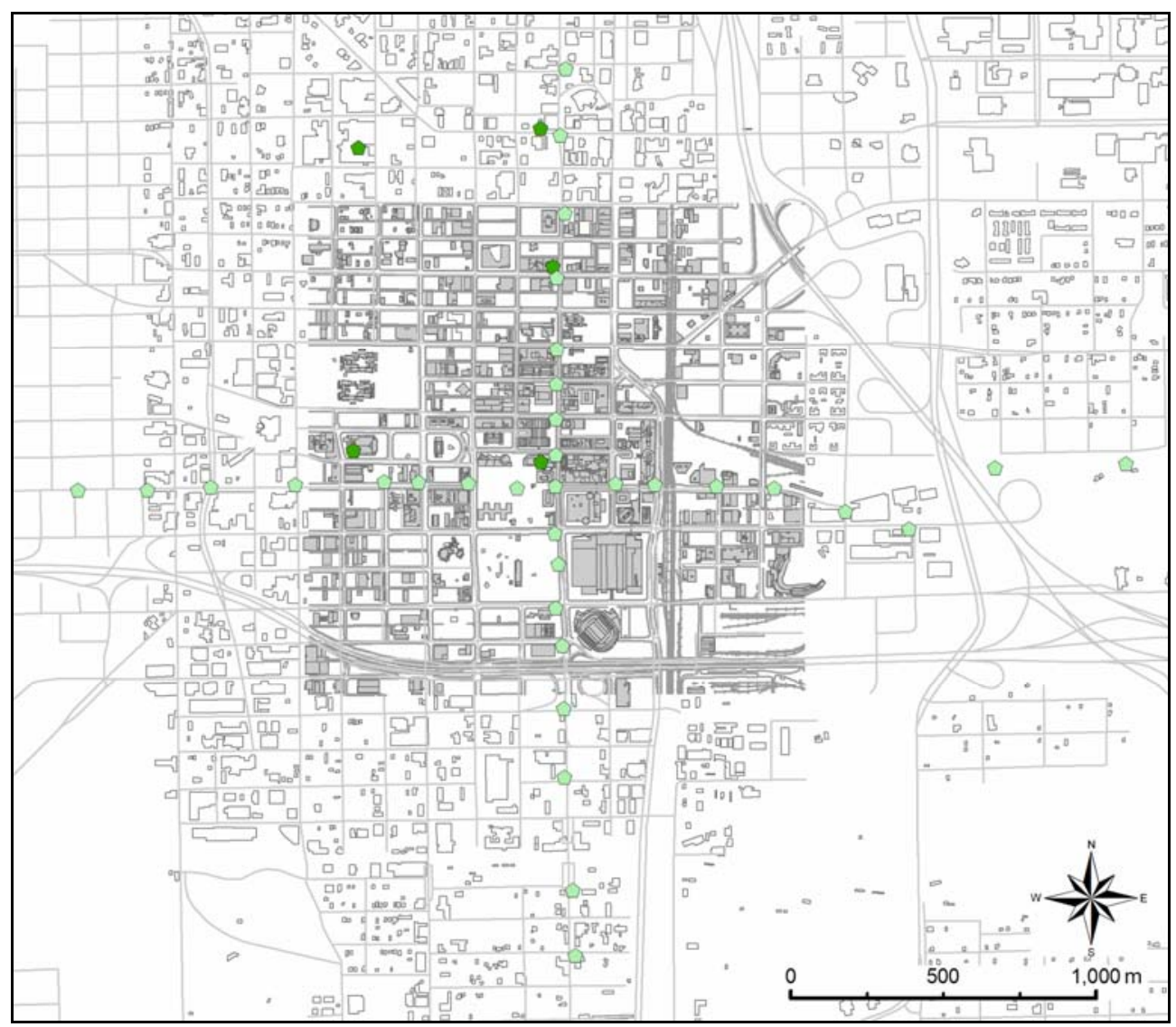

Figure A.33. Overview of PNNL Meteorological Station and HOBO Locations. Dark green pentagons represent meteorological stations, while light green pentagons are HOBOs.
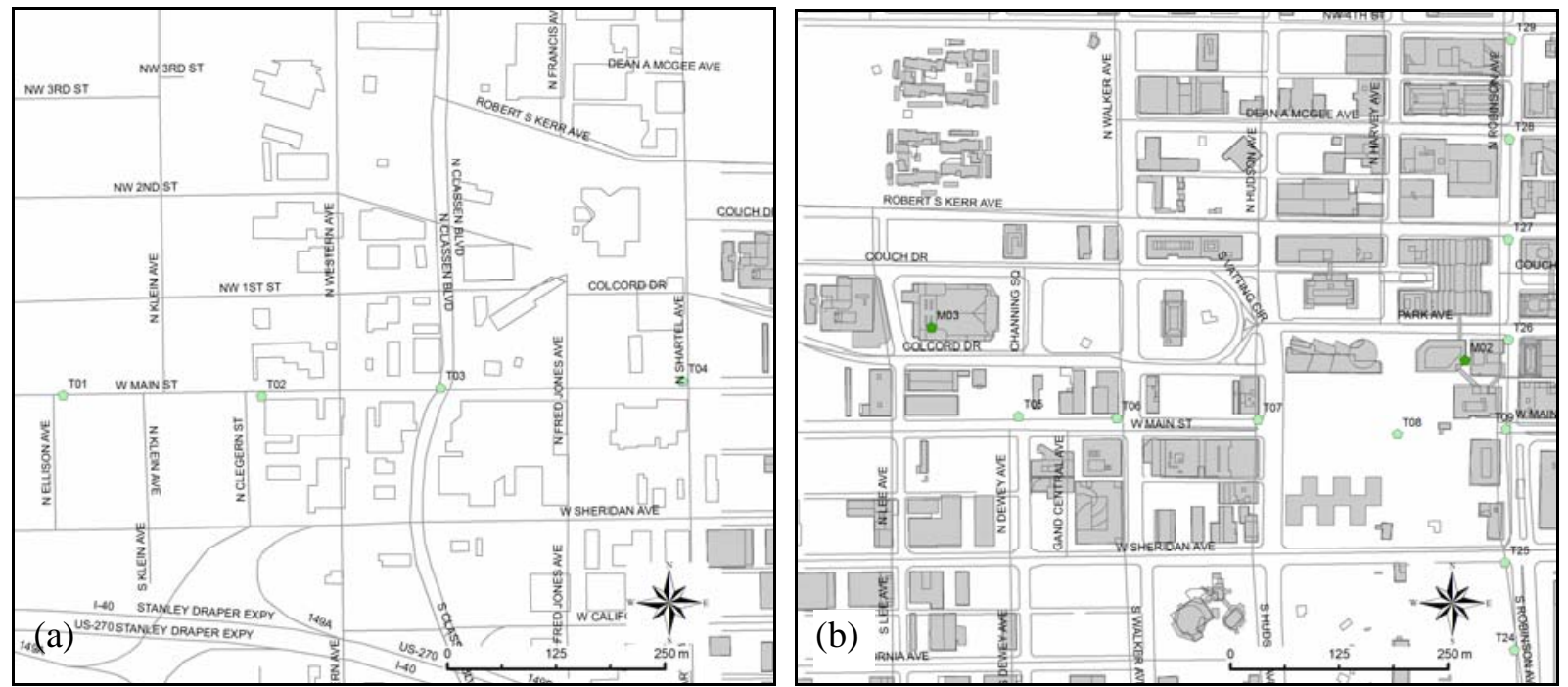

Figure A.34. PNNL HOBO and Meteorological Station Locations. Light green pentagons represent HOBOS while dark green pentagons are meteorological stations. (a) through (d) show instruments from west to east, while (e) through (h) show instruments from south to north. 

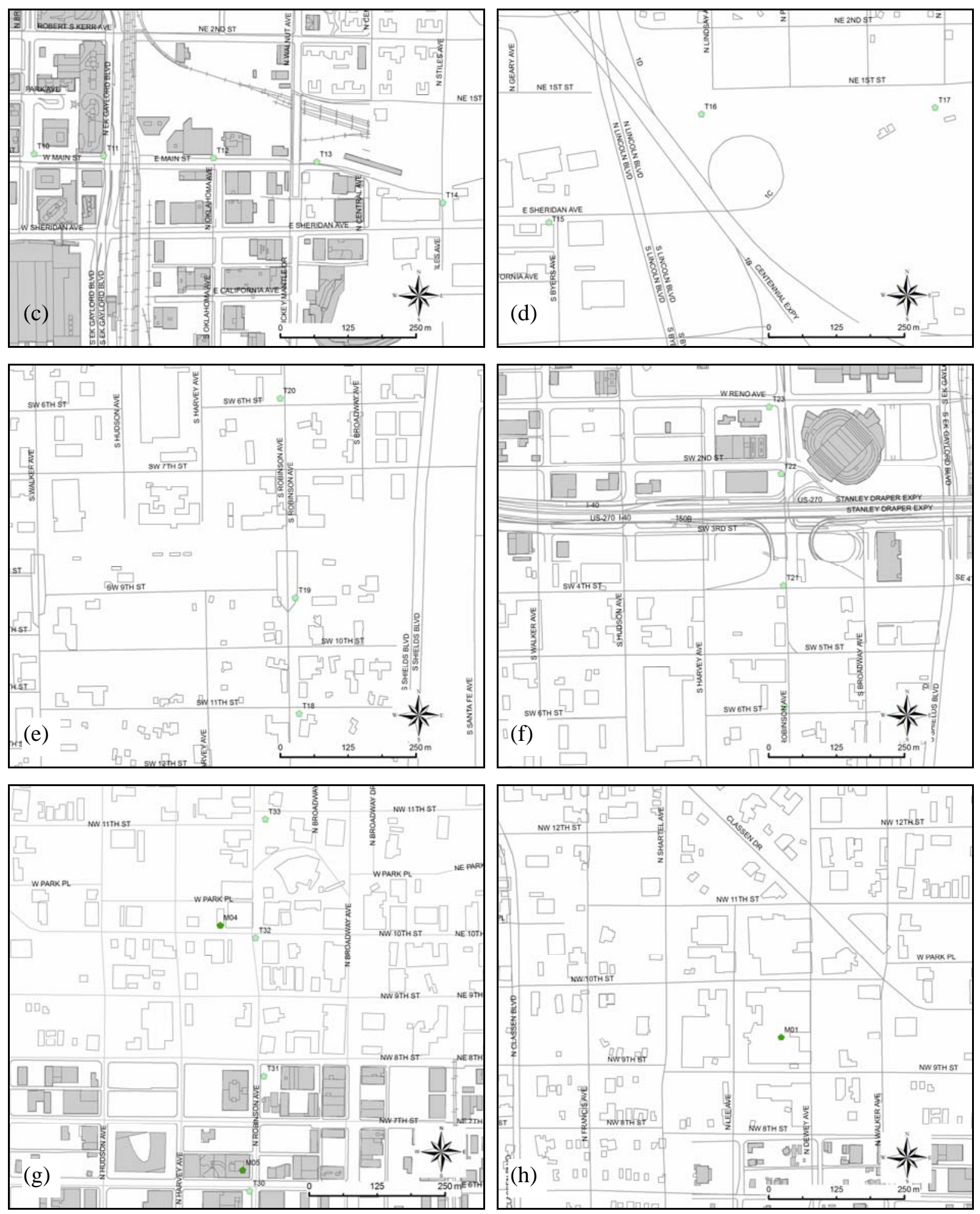

Figure A.34. (Contd) 


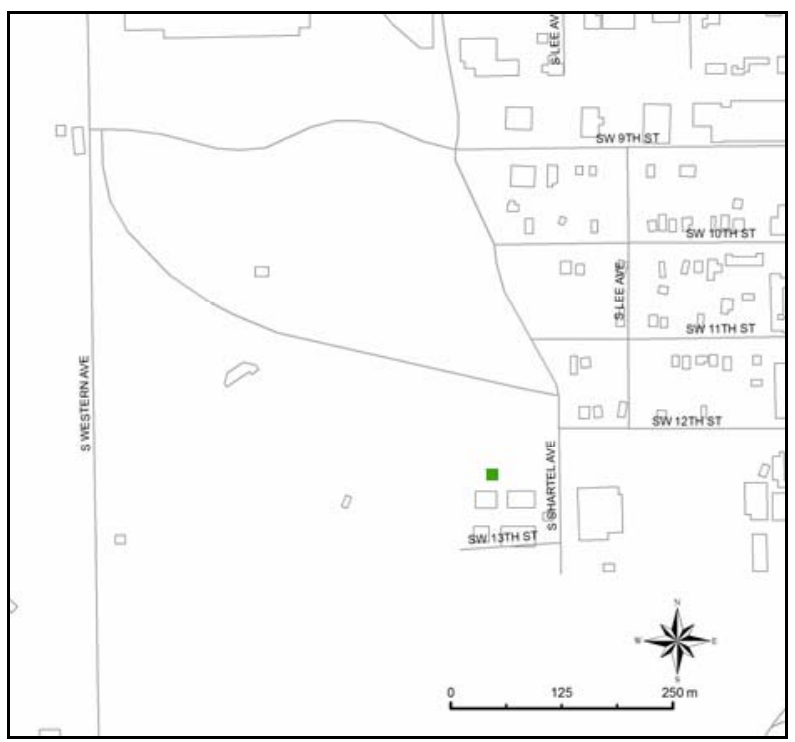

Figure A.35. PNNL Profile Site at Shartel Avenue

\section{A.15 University of Houston}

The University of Houston deployed a sodar about $1.5 \mathrm{~km}$ northwest of downtown Oklahoma City. Data was collected continuously from this site for the duration of the field study. Table A.22 presents the coordinates of this instrument, while Figure A.36 shows the instrument location on a map.

Table A.22. UH Sodar Location

\begin{tabular}{|c|c|c|c|c|c|}
\hline Instrument & Location Description & Latitude & Longitude & Easting & Northing \\
\hline sodar & E E edge of pkg lot btwn 10th \& 11th and Walker \& Hudson & 35.47941 & 97.52039 & 634230 & 3927216 \\
\hline
\end{tabular}
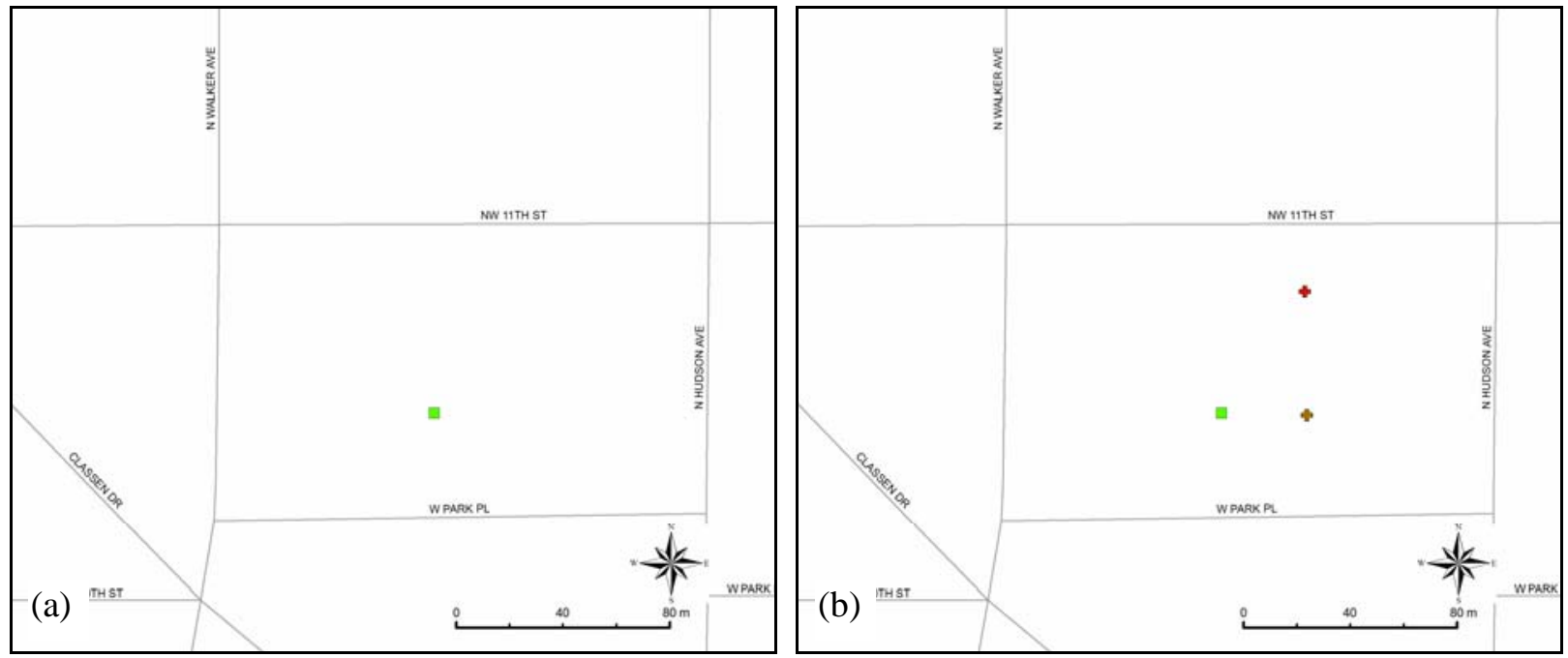

Figure A.36. UH Sodar Location (a) with only the UH Instrument, and (b) with Neighboring ATDD and ASU Instruments 


\section{A.16 University of Utah}

The University of Utah deployed three 3D sonic anemometer towers and one tethersonde in Park Avenue and a minisodar on a parking garage to the northeast of Park Avenue. The sonic anemometers and minisodar operated continuously throughout the study period, while the tethersonde was deployed only during the IOPs. The coordinates of these instruments are presented in Table A.23 and the locations are shown in Figure A.37.

Table A.23. UU Sonic Anemometer and Profile Measurement Locations

\begin{tabular}{|c|c|c|c|c|c|}
\hline Instrument & Location Description & Latitude & Longitude & Easting & Northing \\
\hline 3D Sonic 2 & Chamber of commerce rooftop [19m agl] & 35.469031 & 97.515506 & 634690.0 & 3926071.4 \\
\hline 3D Sonic 4 & Chamber of commerce rooftop [20.5m agl] & 35.469031 & 97.515506 & 634690.0 & 3926071.4 \\
\hline 3D Sonic 9 & Chamber of commerce rooftop [22m agl] & 35.469031 & 97.515506 & 634690.0 & 3926071.4 \\
\hline 3D sonic 1 & City business center rooftop [6m agl] & 35.469095 & 97.515215 & 634716.3 & 3926078.9 \\
\hline 3D sonic 6 & City business center rooftop [8m agl] & 35.469095 & 97.515215 & 634716.3 & 3926078.9 \\
\hline 3D sonic 7 & City business center rooftop [10m agl] & 35.469095 & 97.515215 & 634716.3 & 3926078.9 \\
\hline 3D sonic 3 & 100 Park Ave tower $[3.19 \mathrm{~m}$ agl] & 35.468738 & 97.515942 & 634650.9 & 3926038.3 \\
\hline 3D sonic 5 & 100 Park Ave tower [4.19m agl] & 35.468738 & 97.515942 & 634650.9 & 3926038.3 \\
\hline 3D sonic 8 & 100 Park Ave tower [5.04m agl] & 35.468738 & 97.515942 & 634650.9 & 3926038.3 \\
\hline 3D sonic 10 & 100 Park Ave tower [7.24m agl] & 35.468738 & 97.515942 & 634650.9 & 3926038.3 \\
\hline 3D sonic 11 & 100 Park Ave tower [9.84m agl] & 35.468738 & 97.515942 & 634650.9 & 3926038.3 \\
\hline minisodar & $\begin{array}{l}\text { Broadway-Kerr parking garage. North of } \\
\text { Bank One Bldg [17m agl] }\end{array}$ & 35.46994 & 97.51416 & 634811 & 3926174 \\
\hline tethersonde & $\begin{array}{l}\text { S side of Park W of Broadway South of } \\
\text { Sonic Bldg }\end{array}$ & 866 & 479 & 756 & 031 \\
\hline
\end{tabular}
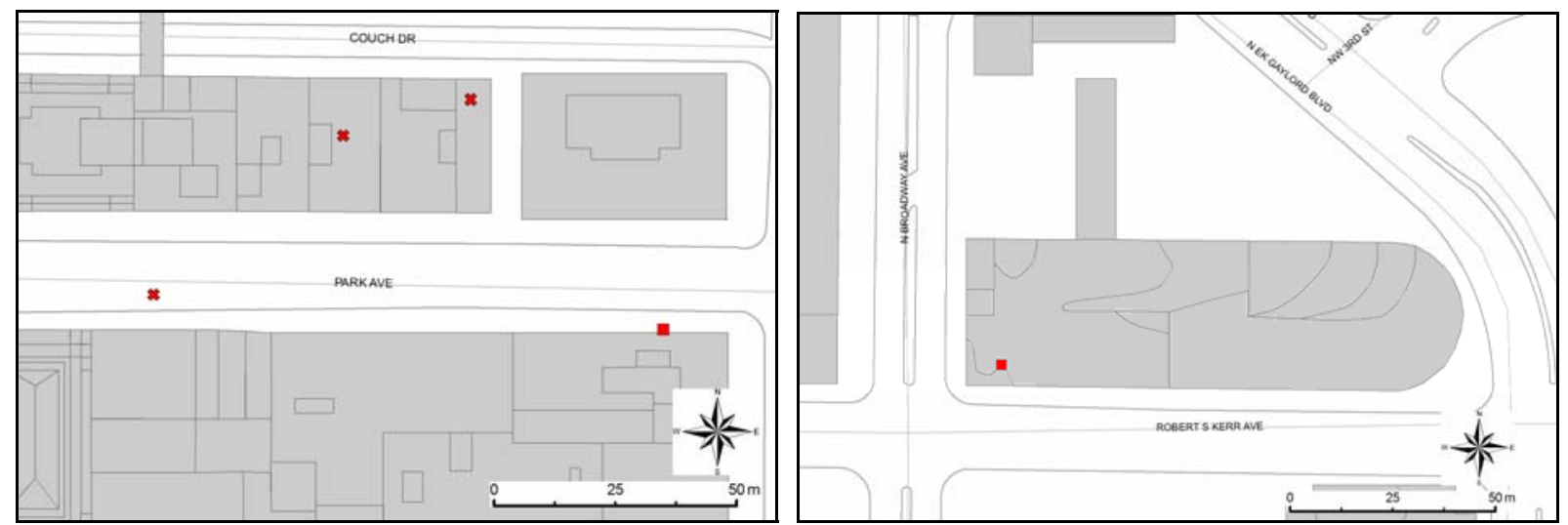

Figure A.37. UU Sonic Anemometer (red X’s) and Profile (red boxes) Measurement Locations (a) in Park Ave and (b) on the Broadway-Kerr Parking Garage 


\section{A.17 Volpe/University of Central Florida}

Volpe/University of Central Florida deployed tracer sampler instruments called MiniVols in two different configurations. Configuration 1 was used when the release location was at the Westin Hotel or in Park Avenue (IOPs 1,2,8,9, \& 10). Configuration 2 was used when the release occurred at the Botanical Gardens on Robinson (IOPs 3 though 7). Two 2D sonic anemometers were also deployed at fixed locations during each IOP. Table A.24 presents the coordinates of the Volpe instruments, while Figures A.38 through A.40 shows the locations on maps.

Table A.24. Volpe Tracer Sampler and Sonic Anemometer Locations

\begin{tabular}{|l|l|c|c|c|c||}
\hline Instrument & Location Description & Latitude & Longitude & Easting & Northing \\
\hline \hline MiniVol 1-1 & $\begin{array}{l}\text { NE corner of Robinson \& Park abt 1m SW of City } \\
\text { Place Bldg }\end{array}$ & 35.46888 & 97.51637 & 634612 & 3926054 \\
\hline MiniVol 1-3 & N side of Park btwn Robinson \& Broadway & 35.46883 & 97.51576 & 634667 & 3926049 \\
\hline MiniVol 1-5 & N side of Park btwn Robinson \& Broadway & 35.46882 & 97.51516 & 634722 & 3926049 \\
MiniVol 1-7 & $\begin{array}{l}\text { NW corner of Broadway \& Park abt 2m E of Sonic } \\
\text { Bldg }\end{array}$ & 35.46886 & 97.51463 & 634770 & 3926054 \\
\hline MiniVol 1-9 & $\begin{array}{l}\text { SE corner of Robinson \& Park abt 1m NW of 1st } \\
\text { Natl Bldg }\end{array}$ & 35.46868 & 97.51637 & 634612 & 3926031 \\
\hline MiniVol 1-11 & S side of Park btwn Robinson \& Broadway & 35.46870 & 97.51577 & 634667 & 3926034 \\
\hline MiniVol 1-13 & S side of Park btwn Robinson \& Broadway & 35.46871 & 97.51516 & 634722 & 3926036 \\
\hline MiniVol 1-15 & $\begin{array}{l}\text { SW corner of Broadway \& Park abt 3m NE of 1st } \\
\text { Natl Bldg }\end{array}$ & 35.46866 & 97.51463 & 634770 & 3926031 \\
\hline MiniVol 2-1 & $\begin{array}{l}\text { NE corner of Robinson \& Park abt 1m SW of City } \\
\text { Place Bldg }\end{array}$ & 35.46888 & 97.51637 & 634612 & 3926054 \\
\hline MiniVol 2-3 & $\sim 18 m$ east of Robinson on N side of Main & 35.46780 & 97.51618 & 634631 & 3925934 \\
\hline MiniVol 2-5 & E side of Robinson btwn Main \& Sheridan & 35.46699 & 97.51624 & 634627 & 3925844 \\
\hline MiniVol 2-7 & $\sim 30 m$ east of Robinson on N side of Sheridan & 35.46663 & 97.51594 & 634655 & 3925805 \\
\hline MiniVol 2-9 & $\begin{array}{l}\text { SE corner of Robinson \& Park abt 1m NW of 1st } \\
\text { Nat'l Bldg }\end{array}$ & 35.46868 & 97.51637 & 634612 & 3926031 \\
\hline MiniVol 2-11 & SW corner of Robinson \& Main & & & & \\
\hline MiniVol 2-13 & W side of Robinson btwn Main \& Sheridan & 35.46699 & 97.51651 & 634601 & 3925907 \\
\hline MiniVol 2-15 & NW corner of Robinson \& Sheridan & 35.46665 & 97.51650 & 634603 & 3925844 \\
\hline 2D sonic & N side of Park $~$ & 634603 & 3925806 \\
\hline 2D sonic from bldg corner at Robinson & S side of Park $~$ & 35.46887 & 97.51629 & 634619 & 3926053 \\
\hline
\end{tabular}




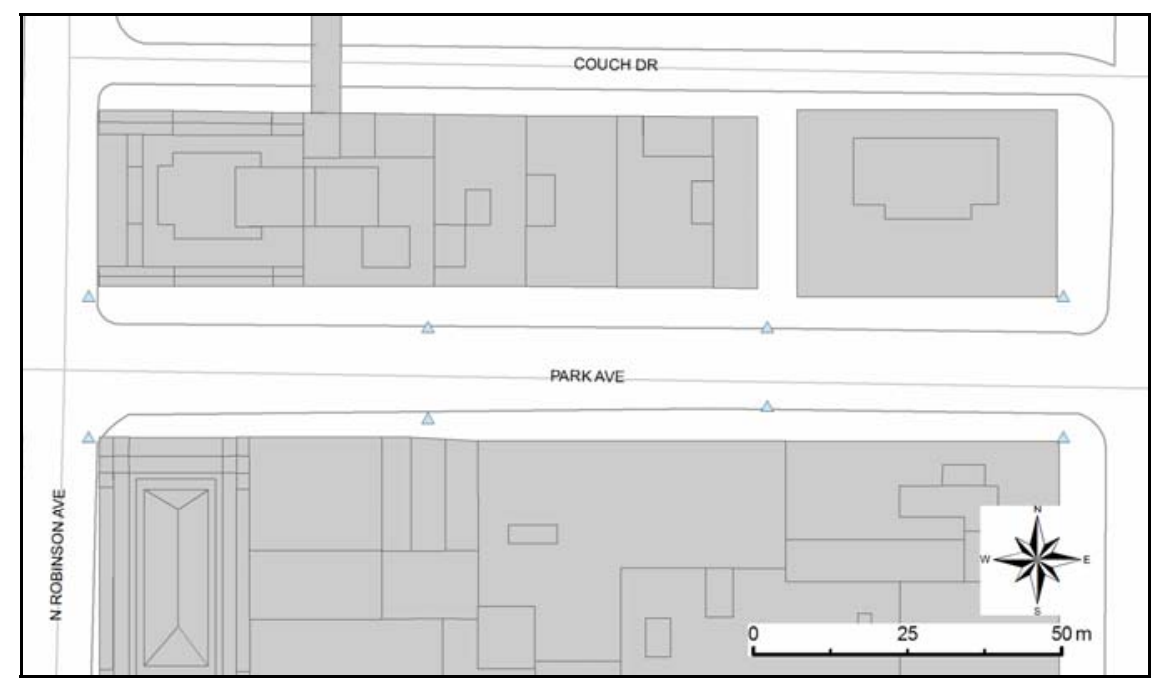

Figure A.38. Volpe MiniVol Configuration 1

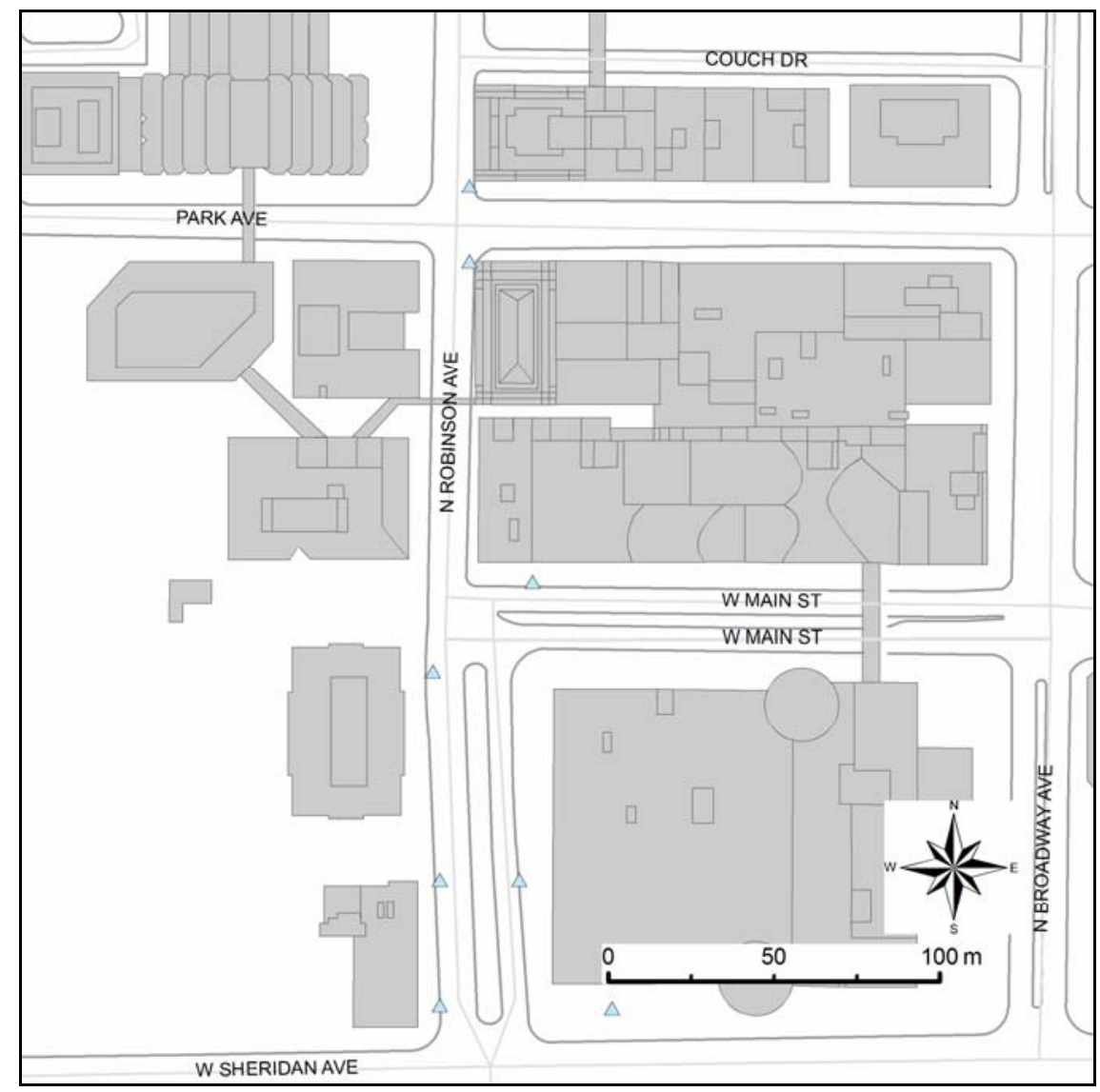

Figure A.39. Volpe MiniVol Configuration 2 


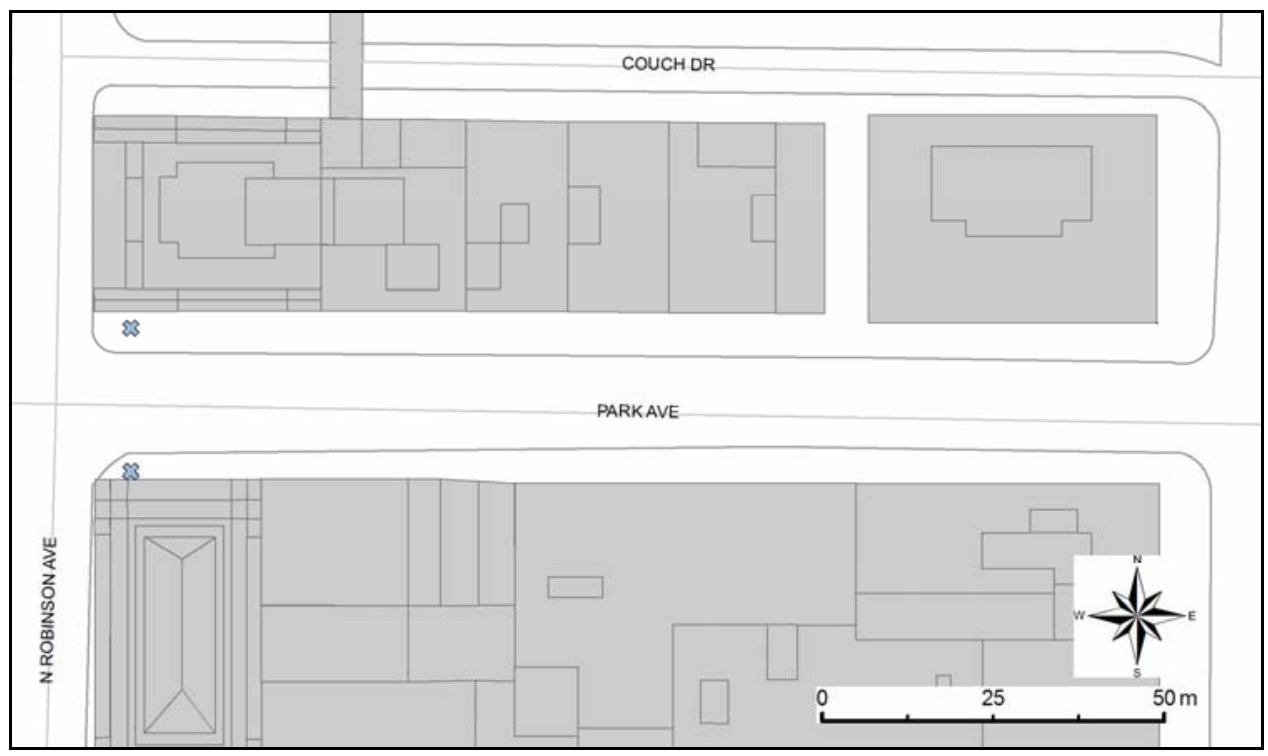

Figure A.40. Volpe Sonic Anemometer Locations

\section{A.18 Washington State University}

Washington State University deployed a tracer profiler system mounted on a crane (with the LLNL sonic anemometers) about $1 \mathrm{~km}$ north of downtown Oklahoma City. The coordinates of the tracer inlets are presented in Table A.25, and the location is shown in Figure A.41.

Table A.25. WSU Tracer Profiler Location

\begin{tabular}{||l|l|r|r|r|r||}
\hline Instrument & Location Description & Latitude & Longitude & Easting & Northing \\
\hline \hline SF6 sampler 10.7m agl & SW corner of 8th \& Harvey & 35.47572 & 97.51785 & 634466 & 3926810 \\
\hline SF6 sampler 17.5m agl & SW corner of 8th \& Harvey & 35.47572 & 97.51785 & 634466 & 3926810 \\
\hline SF6 sampler 24.4m agl & SW corner of 8th \& Harvey & 35.47572 & 97.51785 & 634466 & 3926810 \\
\hline SF6 sampler 34.7m agl & SW corner of 8th \& Harvey & 35.47572 & 97.51785 & 634466 & 3926810 \\
\hline SF6 sampler 48.4m agl & SW corner of 8th \& Harvey & 35.47572 & 97.51785 & 634466 & 3926810 \\
\hline SF6 sampler 62.1m agl & SW corner of 8th \& Harvey & 35.47572 & 97.51785 & 634466 & 3926810 \\
\hline SF6 sampler 75.8m agl & SW corner of 8th \& Harvey & 35.47572 & 97.51785 & 634466 & 3926810 \\
\hline
\end{tabular}




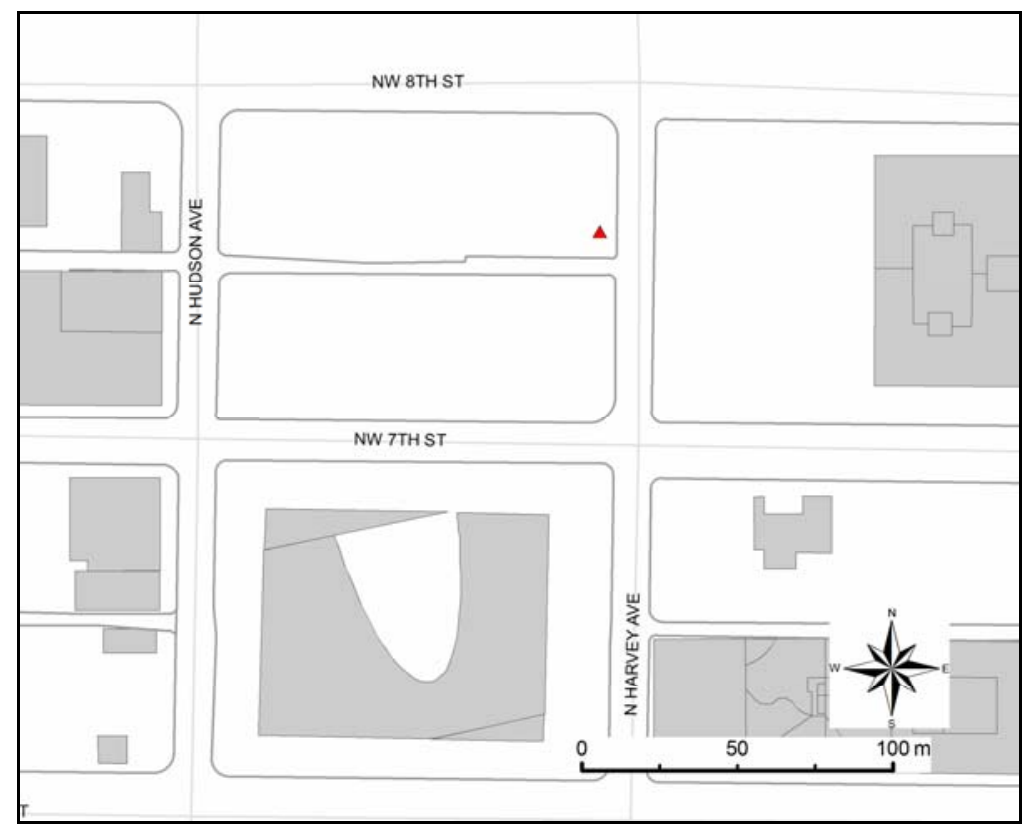

Figure A.41. WSU Tracer Profiler Location 


\section{Appendix B}

The following table, Table B.1, presents a summary of the principal investigators from each of the participating institutions. Additionally, Table B.2 presents all of the study participants from the various institutions. The Joint Urban 2003 lead scientist was Jerry Allwine (PNNL) who oversaw study design, logistical arrangements and field operations with the help of Joe Shinn (LLNL), Marty Leach (LLNL), Ray Hosker (ATDD), Leo Stockham (NGIT) and Jim Bowers (DPG).

Table B.1. Summary of Principal Investigators from the Participating Institutions of the Joint Urban 2003 Study

\begin{tabular}{|l|l|l||}
\hline Participating Institution & $\begin{array}{l}\text { Principal } \\
\text { Investigator }\end{array}$ & Email \\
\hline \hline Argonne National Laboratory & Rich Coulter & rlcoulter@anl.gov \\
\hline Army Research Laboratory & Dennis Garvey & dgarvey@arl.army.mil \\
\hline $\begin{array}{l}\text { NOAA Air Resources Laboratory - Field Research } \\
\text { Division }\end{array}$ & Kirk Clawson & kirk.clawson@noaa.gov \\
\hline Arizona State University & $\begin{array}{l}\text { Ron Calhoun } \\
\text { Marko Princevac }\end{array}$ & $\begin{array}{l}\text { ronald.calhoun@asu.edu } \\
\text { marko@eng.ucr.edu }\end{array}$ \\
\hline $\begin{array}{l}\text { NOAA Air Resources Laboratory - Atmospheric } \\
\text { Turbulence and Diffusion Division }\end{array}$ & Ray Hosker & ray.hosker@noaa.gov \\
\hline Dugway Proving Ground & $\begin{array}{l}\text { Jim Bowers } \\
\text { Donny Storwold }\end{array}$ & $\begin{array}{l}\text { jbowers@dpg.army.mil } \\
\text { storwold@dpg.army.mil }\end{array}$ \\
\hline Defense Science and Technology Laboratory & Nicola Felton & nvfelton@mail.dstl.gov.uk \\
\hline ITT Industries & Don Burrows & don.burrows@itt.com \\
\hline Indiana University & Sue Grimmond & $\begin{array}{l}\text { Sue.Grimmond@kcl.ac.uk } \\
\text { (currently with King's College London) }\end{array}$ \\
\hline Los Alamos National Laboratory & Michael Brown & mbrown@lanl.gov \\
\hline Lawrence Berkeley National Laboratory & Rich Sextro & rgsextro@lbl.gov \\
\hline Lawrence Livermore National Laboratory & $\begin{array}{l}\text { Marty Leach } \\
\text { Joe Shinn }\end{array}$ & $\begin{array}{l}\text { leach6@llnl.gov } \\
\text { shinn1@llnl.gov }\end{array}$ \\
\hline Oklahoma Climatological Survey & Jeff Basara & jbasara@ou.edu \\
\hline University of Oklahoma & Petra Klein & pkklein@ou.edu \\
\hline Pacific Northwest National Laboratory & Jerry Allwine & jerry.allwine@pnl.gov \\
\hline Edgewood Chemical Biological Center & Francis D’Amico & fran.damico@us.army.mil \\
\hline University of Central Florida & Roger Wayson & wayson@ucf.edu \\
\hline University of Houston & Shiyuan Zhong & szhong@uh.edu \\
\hline University of Utah & Eric Pardyjak & pardyjak@eng.utah.edu \\
\hline DOT - Volpe & Gregg Fleming & gregg.g.fleming@volpe.dot.gov \\
\hline Washington State University & Brian Lamb & blamb@wsu.edu \\
\hline
\end{tabular}

B.1 
Table B.2. Summary of Participants in the Joint Urban 2003 Study

\begin{tabular}{|c|c|c|}
\hline \multirow{2}{*}{$\begin{array}{l}\text { Participating Institution } \\
\text { Argonne National Laboratory (ANL) }\end{array}$} & \multicolumn{2}{|c|}{ Participant } \\
\hline & Rich Coulter & Tim Martin \\
\hline & Erin Hockanson & Mikhail Pekour \\
\hline \multirow[t]{11}{*}{ Army Research Laboratory (ARL) } & Dennis Garvey & Walter Bach \\
\hline & Ronald Cionco & Young Yee \\
\hline & Chat Williamson & Dave Quintis \\
\hline & David Ligon & Ed Creegan \\
\hline & Ed Vidal & Gail Vaucher \\
\hline & Giap Huyhn & James Cogan \\
\hline & Jimmy Yarbrough & John Noble \\
\hline & Raymond Pickering & Manny Bustillos \\
\hline & Mario Torres & Alan Mariner \\
\hline & Yansen Want & Shaun Jackson \\
\hline & Sam Chang & Scott Elliott \\
\hline \multirow{7}{*}{$\begin{array}{l}\text { NOAA Air Resources Laboratory- Field Research } \\
\text { Division (ARLFRD) }\end{array}$} & Kirk Clawson & Roger Carter \\
\hline & Debbie Lacroix & Tom Watson \\
\hline & Randy Johnson & Janna Goldman \\
\hline & Bradley Reese & Neil Hukari \\
\hline & Bob McMillen & Camille Erwin \\
\hline & David George & Dianne Hoover \\
\hline & Mark Hoover & Chris Biltoft \\
\hline \multirow[t]{3}{*}{ Arizona State University (ASU) } & Ron Calhoun & Marko Princevac \\
\hline & Joe Fernando & Dragah Zajic \\
\hline & John Holeman & Rob Heap \\
\hline \multirow{4}{*}{$\begin{array}{l}\text { NOAA Air Resources Laboratory - Atmospheric } \\
\text { Turbulence and Diffusion Division (ATDD) }\end{array}$} & Ray Hosker & Laureen Gunter \\
\hline & Carmen Nappo & Mark Heuer \\
\hline & Randy Meyer & Randy White \\
\hline & Will Stachowiak & \\
\hline \multirow[t]{3}{*}{ Centers for Disease Control and Prevention (CDC) } & Duanne Hammond & Ken Mead \\
\hline & Mike Gressel & Rebecca Valladares \\
\hline & Scott Earnest & \\
\hline Colorado State University (CSU) & Rob Newsom & \\
\hline \multirow[t]{5}{*}{ Dugway Proving Ground (DPG) } & Jim Bowers & Donny Storwold \\
\hline & Erik Vernon & Scott Halvorson \\
\hline & Frank Gallagher & Frederick Davis \\
\hline & Paul Broderick & Roland Barbero \\
\hline & Bill Grayson & \\
\hline
\end{tabular}


Table B.2 (contd)

\begin{tabular}{|c|c|c|}
\hline \multirow{2}{*}{$\begin{array}{l}\text { Participating Institution } \\
\text { Defense Science and Technology Laboratory (DSTL) }\end{array}$} & \multicolumn{2}{|c|}{ Participant } \\
\hline & Nicola Felton & Ian Griffiths \\
\hline & David Brook & Douglas Strickland \\
\hline \multirow[t]{2}{*}{ Defense Threat Reduction Agency (DTRA) } & John Pace & Linda Ritchie \\
\hline & Rick Fry & \\
\hline \multirow[t]{7}{*}{ ITT Industries (ITT) } & Don Burrows & Steve Diehl \\
\hline & John Betz & John LeSage \\
\hline & Vernon Smith & Alan Gaddy \\
\hline & Bill Schrami & Bob Keith \\
\hline & Chuck Tobin & Eric Hendricks \\
\hline & Gary Paderewski & Greg Boyle \\
\hline & Leldon Troyer & Les Mann \\
\hline \multirow[t]{3}{*}{ Indiana University (IU) } & Sue Grimmond & Hong Bing Su \\
\hline & Brian Offerle & Steve Scott \\
\hline & Ben Crawford & \\
\hline \multirow[t]{4}{*}{ Los Alamos National Laboratory (LANL) } & Michael Brown & Brad Hansen \\
\hline & David Boswell & Gerald Streit \\
\hline & Matt Nelson & Tim Hilton \\
\hline & Tim McPherson & \\
\hline \multirow[t]{4}{*}{ Lawrence Berkeley National Laboratory (LBNL) } & Rich Sextro & Tracy Thatcher \\
\hline & Woody Delp & Doug Black \\
\hline & Emily Wood & Mark Sippola \\
\hline & Toshifumi Hotchi & \\
\hline \multirow[t]{6}{*}{ Lawrence Livermore National Laboratory (LLNL) } & Marty Leach & Joe Shinn \\
\hline & Frank Gouveia & Bill Ralph \\
\hline & Garrett Keating & Tom Humphreys \\
\hline & Julie Lundquist & Branko Kosovic \\
\hline & Don Ermak & Marshall Stuart \\
\hline & Ronald Leif & Ronald Pletcher \\
\hline Northrop Grumman Information Technology (NGIT) & Leo Stockham & Tom Mazzola \\
\hline \multirow[t]{15}{*}{ Oklahoma Climatological Survey (OCS) } & Jeff Basara & Peter Hall \\
\hline & Cerry Leffler & Aaron Kennedy \\
\hline & Andy Moore & Ben Baranowski \\
\hline & Brad Illston & Brianna Patterson \\
\hline & Chad Ringley & Christy Carlson \\
\hline & Danny Cheresnick & Don Giuliano \\
\hline & Grant Stewart & Justin Monroe \\
\hline & Ken Crawford & Kevin Kloesel \\
\hline & Kodi Nemunaitis & Kristen Poole \\
\hline & Kyle Walker & Loucinda Smith \\
\hline & Lynn Perkinton & Matt Shawhan \\
\hline & Matt Haugland & Megan Ferris \\
\hline & Michael James & Michael Morris \\
\hline & Ryan Barnes & Sarah Davis \\
\hline & Renee McPherson & \\
\hline
\end{tabular}

B. 3 
Table B.2 (contd)

\begin{tabular}{|c|c|c|}
\hline \multirow{2}{*}{$\begin{array}{l}\text { Participating Institution } \\
\text { University of Oklahoma (OU) }\end{array}$} & \multicolumn{2}{|c|}{ Participant } \\
\hline & Petra Klein & Daniel Walker \\
\hline & May Yuan & Mang Lung Cheuk \\
\hline & John Snow & Geoff Maas \\
\hline & James Clark & T.H. Lee Wiliams \\
\hline & Melissa Moon & \\
\hline University of Oklahoma Health Sciences Center (HSC) & M. Muntimagadu & Sridhar Agraharam \\
\hline \multirow[t]{8}{*}{ University of Oklahoma REU (REU) } & Allen Logan & Andrew Hamm \\
\hline & Becca Mazur & Christy Nestlerode \\
\hline & Corey Potvin & Dustin Rapp \\
\hline & Jenny Esker & Marc Dahmer \\
\hline & Maura Hahnenberger & Melissa Walker \\
\hline & Mike Charles & Nick Metz \\
\hline & Tina Kalb & Victoria Sankovich \\
\hline & Aaron Barclay & \\
\hline \multirow[t]{4}{*}{ Pacific Northwest National Laboratory (PNNL) } & Jerry Allwine & Will Shaw \\
\hline & Larry Berg & Stephan DeWekker \\
\hline & Geoffrey Harvey & Duard Crandal \\
\hline & Brad Fritz & \\
\hline Edgewood Chemical Biological Center (ECBC) & Francis D’Amico & \\
\hline \multirow[t]{7}{*}{ Redstone Arsenal Airfield (RAA) } & Aaron Allen & Bill Cruger \\
\hline & Blake Pattillo & Chris Teague \\
\hline & Chuck Ricketts & Danny Rinehart \\
\hline & Jeffrey Smith & John Burkhead \\
\hline & Les Haas & Ned Norton \\
\hline & Russ Matteo & Samuel Maki \\
\hline & Tim Collins & Tim Ricks \\
\hline \multirow[t]{2}{*}{ Texas Tech University (TTU) } & Caleb Midgley & Gabriel Rothman \\
\hline & John Schroeder & Thomas Gill \\
\hline University of Central Florida (CFU) & Roger Wayson & \\
\hline University of Hamburg (UH) & Bernd Leitl & Frauke Pascheke \\
\hline \multirow[t]{5}{*}{ University of Houston (UH) } & Shiyuan Zhong & Craig Clements \\
\hline & Alex Cuclis & Bonnie Cheng \\
\hline & Daewon Byun & Hee-Jin In \\
\hline & Soontae Kim & Seung-Burn Kim \\
\hline & Violeta Coarfa & \\
\hline \multirow[t]{3}{*}{ University of Utah (UU) } & Eric Pardyjak & Joe Klewicki \\
\hline & Prathap Ramamurthy & Suhas Pol \\
\hline & Brett Verhoeff & James Allison \\
\hline \multirow[t]{2}{*}{ DOT - Volpe } & Gregg Fleming & George Noel \\
\hline & John McDonald & \\
\hline \multirow[t]{2}{*}{ Washington State University (WSU) } & Brian Lamb & Eugene Allwine \\
\hline & Julia Flaherty & Tara Strand \\
\hline
\end{tabular}




\section{Distribution}

No. of

Copies

\section{OFFSITE}

1 Donny Storwold

U.S. Army Dugway Proving Ground

Meteorology Division

CSTE-DTC-DP-ME-M

Building 4034 / Room 111

Dugway, UT 84022-5000

(435) 831-5496

1 Teresa Lustig

Department of Homeland Security

Attn: S\&T/Teresa Lustig/4-5766

Anacostia Naval Annex

245 Murray Lane, SW, Building 410

Washington, DC 20528

(202) 254-5766

[send FedEx/UPS]

\section{ONSITE}

13 Pacific Northwest National Laboratory Information Release (2) P8-55

K.J. Allwine (10) K9-30

J.E. Flaherty (1) K9-30

Distr. 1 